\title{
International Journal of American Linguistics
}

Volume I

May, I9I 8

Number 2

\section{TEPECANO PRAYERS}

By J. ALdEN MASON

\section{INTRODUCTION}

$\mathrm{T}$ HE following prayers or perdones as they are locally termed were collected during the months of December, I9I I, to March, I9I2, and from November of the latter year to January, I9I3, while I was enjoying the facilities for field work afforded me as representative from the University of Pennsylvania to the International School of Mexican Ethnology and Archeology. They were secured in Azqueltán, a little pueblo in the northeastern corner of the state of Jalisco, some hundred miles west of Zacatecas and nearly the same distance north of Guadalajara. Here live the remainder of the Tepecanos, at present the southernmost people speaking a language of the Piman group. A brief sketch of their life and customs ${ }^{1}$ and collections of their folktales ${ }^{2}$ have been published as well as a short account of one of the religious fiestas. ${ }^{3}$

The principal results of the residence in Azqueltán, in addition to the above-mentioned sketches, were studies of the language and of the religion of this group. An exposition of the language is being published by the New York Academy of Sciences. ${ }^{4}$ To the same Academy is due no little credit for the appearance of the present paper, since it supplied

\footnotetext{
1 The Tepehuán Indians of Azqueltán, Proceedings of the XVIII International Congress of Americanists, London, I912, p. 344 .

${ }^{2}$ Four Mexican-Spanish Fairy-Tales from Azqueltán, Jalisco, J. A. F. L., XXV, p. I9I; Folk-Tales of the Tepecanos, ibid., XXVII, p. I48.

${ }^{3}$ The Pinole Fiesta at Azqueltán, University of Pennsylvania Museum Journal, III, p. 44.

${ }^{4}$ Tepecano, A Piman Language of Western Mexico, Annals of the New York Academy of Sciences. The appearance of this article is delayed on account of the war.
}

the needed funds for its preparation. The present collection of prayers is presented partly as illustrative material for the aforesaid linguistic sketch and partly as basic material for the study of the religion which is to be prepared. For this reason the prayers are presented with little introduction and no attempt has been made to explain the ceremonial allusions. Footnotes have been appended only to elucidate grammatical points.

The greater number of the prayers were given me by my principal informant, Eleno Aguilar. A few were given by the Cantador Mayor or High Priest, Rito de la Cruz, and one was secured from Francisco Aguilar. But all were revised and corrected by Eleno.

The religion of the Tepecanos appears to be very similar to those of the other neighboring peoples of the Sierra Madre Occidental, the Huichol, Cora, Tepehuane and Tarahumare. Preuss has published a voluminous account of the religion of the Cora ${ }^{5}$ and Lumholtz more or less detailed accounts of those of the other groups, ${ }^{6}$ particularly the Huichol. ${ }^{7}$ The religion of the latter appears to be somewhat specialized but those of the other groups are doubtless basically the same. Preuss gives many songs and prayers very similar in form and concept to those given here and Lumholtz mentions the same among other groups.

${ }^{5}$ K. T. Preuss, Die Religion der Cora-Indianer, Leipzig, I9I2, and many smaller articles in various periodicals.

${ }^{6}$ Karl Lumholtz, Unknown Mexico, New York, I902, and several smaller articles.

${ }^{7}$ Symbolism of the Huichol Indians, Memoirs of the American Museum of Natural History, New York, III, May, 1900, and other papers. 
The old Tepecano religion is now practically abandoned in favor of Catholicism and the Christian influence may be traced in several of the prayers. Fortunately it is slight. But it must be borne in mind that the prayers are traditional material and many have not been recited for years. Probably a large number have been lost beyond possibility of record. The possibility of inaccuracy is therefore considerable. In many cases, the exact meaning of esoteric phrases has been forgotten or they are interpreted differently by different informants. In other cases the purpose of the prayer itself is disputed by various authorities or changes suggested in the final revision. It is with a full realization of these possible inaccuracies that the collection is presented.

For the greater part, the texts have been printed exactly as written down even in cases where cumulative evidence of many records of the same word indicates that a certain instance was incorrectly recorded. In addition to certain regular changes to conform with the orthography now in standard usage,$^{1}$ the principal change in preparation of manuscript has been in the cases of the complexes $p b, t d$, and $k g$ where the initial surd is not released, to $\mathrm{B}^{\cdot}, \mathrm{D}^{\cdot}$, and $\mathrm{G}^{\cdot}$, respectively.

For a complete account of the phonetics and morphology of the language the reader is referred to the before-mentioned linguistic paper. A brief résumé of the phonetic key used is here appended for ready reference:

\section{a as in $\mathrm{arm}$}

e as in end (very rare and probably reduced from

as in machine diphthong $i a)$

o as in orb

$\ddot{o} \quad$ as in urn ( $\ddot{i}$ and $\ddot{u}$ were occasionally written as variants of $\ddot{o}$ )

$\mathbf{u} \quad$ as in rule (approaches $o$ of note)

$\mathrm{y} \quad$ as in yes (generally as an $i$ glide)

$\mathrm{w} \quad$ as in wet (generally as an $u$ glide; also confused

w semi-voiceless $w$ with $v)$

1 Phonetic Transcription of Indian Languages, Smithsonian Miscellaneous Collections, publication 24I.5, Washington, D. C. as in men

semi-voiceless $m$

as in net

semi-voiceless $n$

as in sing (rare)

as in Spanish pero

semi-voiceless $r$

approaching $r$ but untrilled (rare)

as in Spanish pavo

semi-voiceless $v$

as in so

as in show (but approaching $s$ )

as in hat (probably not differentiated from $x$ )

as in Spanish jota (probably not differentiated

from $h$ )

as in bed

as in day

as in $g o$

intermediate surd-sonant $p-b$

intermediate surd-sonant $t$ - $d$

intermediate surd-sonant $k$ - $g$

as in Spanish pero

as in Spanish tan

as in Spanish casa

as in hats (rare)

as in church (rare)

glottal stop or occlusion

accent after vowel denotes stress accent

accent over vowel denotes' pitch accent

grave accent denotes secondary accent

iota subscript denotes nasalization

raised period denotes doubled length

period denotes hesitation, cessation of breath or voice, or separation of normally connected elements of diphthongs or other combinations

superscript characters are pronounced with less than normal force

\section{TO PREPARE THE PATIO FOR THE FIESTA OF THE RAIN}

adiu's.um ${ }^{2}$ naparin. $Q^{\cdot} \mathrm{G}^{3} \quad$ naparinda $\cdot{ }^{\prime} \mathrm{D}^{4}$ To God, ${ }^{2}$ thou who art my Father, ${ }^{3}$ who art my= Mother, ${ }^{4}$

${ }^{2}$ Adios is the most frequent beginning for most of the prayers and is, of course, a Christian influence. It is a question whether it represents a dedication to the Christian God or merely an exclamation of greeting, in which sense it is frequent in Spanish usage. It has been most frequently translated as "Hail!" The particle um here is of doubtful nature.

${ }^{3}$ The stem means FATHER; it has frequently been translated as "Lord."

${ }^{4}$ The stem means MOTHER; it has frequently been translated as "Lady." 
o'gipaskam anihö'.ci'kor hö'van tuma'southerner. Hereabouts there has gone= aGdimök namitpum‘átök gama'dára·iwa conversing, that they knew they already sat namitpubö.át:ö'k höganavarano'v para that they to us have reached that which is their hand in order

natpuha'bantuD`a'gimöD gamtönöídida kuga'that we in it having wrapped ourselves may go beholding. Then

gurahö'mi.iu'rnida höga navaricto'nkam aside will go casting that which is heat höga navara.u"umi.hö'köt' mipuga'gurahö'.that which are their arrows ${ }^{1}$ with they aside will= iu''r'nida ganavaraka'kvarakhö'köt ${ }^{2}$ miputgo casting that which are their chimales $^{2}$ with. They= so'sbidida gahactucko'k·dakám napuböm.a'for us shall go attacking whatever sickness that may=

gida porki a'tiamnö·nö atictu'kipgamtönö'ín come being reported. Because we do not see, we= in darkness go peering porki

because
iti'kradö'köD our filthiness with

ti'cputso'sbidim konki'hapö'gia.í ni'cpuam-we go obstructing ourselves. With which this only $I=$

$a^{\prime}$ tut kupiminka'ök kupimi'tunha.'gicda cause you to know. Then hear ye me. Then ye me= will pardon

nanpui'nicituhá'n hi'di navaramnö'ík·ar.dám that $I$ here meddle this which is your patio in.

kuni'pui'nicikö’sa gana'varam·ai'nig gana'Then I here will place this which is your petate that= varicta' amba'tu.dám ${ }^{3}$ pixö' napimpuma ${ }^{\prime}{ }^{\prime}$ 'git which is white your tapexte ${ }^{3}$ on where that ye= are formed

wös.oras.a'B kunkinicputömaiam·a'tuD all hours in. With which I constantly give you to= know.

kudio'spöcambi'ak'a

Then God feel for you.

${ }^{1} u^{\prime} m i$ is the ceremonial arrow, as distinguished from $u$, the hunting arrow.

${ }^{2}$ Chimal is the native adaptation of the Nahua chimalli, SHIELD. The chimal is the little diagonal or

NOTE

This prayer is recited by the Cantador Mayor, the principal functionary of Tepecano religion, to beg permission of the divinities to clean and prepare the ceremonial patio for the celebration of the Rain Fiesta, the principal fiesta of the year, held on the fifth of April. This is done in the late afternoon. After reciting this, the Cantador, or Chief Singer, sweeps the dance patio, lights the fire and decorates the altar with the necessary ceremonial objects.

\section{TRANSLATION}

Oh ye who are my Lord and my Lady who were created beneath the seven beautiful heavens! Hither have we come to ask your forgiveness so that I may here prepare and may place here these powerful Cidudkam, as they are called hereabouts where they are formed and cherished. Also do I say unto you that ye must forgive me these few words. Continually do I implore you that ye give me leave to work here and to pass the night here that I may kindle fire on this your green carpet.

Thence the heaven becometh overcast and your cloud ariseth, beautifully outspread, which drizzleth and is very green. There is formed the Word of Him who is my Guide, my Morning Star and my Lord, who cometh teaching unto us his hand that we, gathering ourselves into it, may go beholding in all hours. There beneath the east is it formed whence he hath sent his lightning and spoken. From afar it hath arisen; he hath spoken to them of the north, the west and the south, telling to all parts. Thus did they know it; they have seated themselves and have reached unto us their hand that we, wrapping ourselves in it, may go observing.

They will repel the heat with their arrows; with their chimales will they cast it aside. hexagon of yarn, the "God's eye" of the Huichol. To the Tepecanos it is God's face.

${ }^{3}$ Nahua tlapextle, the white cloth erected on the altar. 
They will shield us from whatever pestilence may come. For we may not see and in darkness we grope, for we are vile and with our filthiness we impede ourselves.

This only do I say unto you. Hear ye me! Ye will pardon me for meddling here in this your court. Here will I place your white cloth on your carpet where ye are formed in all hours. Continually do I implore you. May God bless you.

\section{TO COMMENCE THE FIESTA OF THE RAIN}

(PERDÓN MAYOR)

adio's ino.'G inda'D inci'u'G To God, my Lord, my Lady, my Morning Star. ati'puhi'möt aptu'i' napimaringö'"korak ${ }^{1}$ We have come; to be that ye are my manes ${ }^{1}$ a'möhờvan napimarda'dar'kam hö'there that ye are the sitters that= ga·rictumá'm ictö'dog ci"a·r wö't'a is five green east beneath. a'mömö'dör napimivo'pmigda hờga There from that ye will lift that na'varicda'dik'am navarumu"'umi² naв'which is health. Which are thy ${ }^{2}$ ceremonial arrows that $=$ aituda'giuna hög.a na'pgama'.itwï'cturda
thou hither us wilt cleanse that that thou, coming= wilt force away from us

$\begin{array}{llr}\text { hög·ac'ko'k·dakam } & \text { aric·i'ko'r } & \text { umtö' } \\ \text { that sickness } & \text { is vicinity } & \text { thy= }\end{array}$
tvagiwöpta a'bi'dör na'puiwu'wacda skies beneath. There from thou wilt stlect navarumvo'p`oikam a'nihödör naB'ai'which is thy path. Here from that thou= tuda'giuna hö'ga navaricxö'pitkam ${ }^{3}$ hither us wilt cleanse that which is the coldness ${ }^{3}$

1 Translated "Our Fathers and Mothers of the heavens." It is not quite certain whether these are the major divinities, minor divinities or ancestral spirits.

2 The changes in person in this and other prayers are very confusing. Their signification is most puzzling.

navarumno'v hó'köt na'puhö'köt.itka'which is thy hand with; that thou with it for us= pkaturda navarum.ớra'dakam napit'ö'wilt constrain which is thy inwardness; that= vörturda höga navarumhi•'Mda thou for us wilt lengthen that which is thy way napgamipkitöt'kö'hiniD’a höga navaruma'which thou also now us wilt cause to tread that which is=

t'vagi.sa·'giD ku·hidi'köD apictunha'gicda thy altar between. Then this with thou me wilt= pardon,

$d i o^{\prime} s$ in. $0^{\circ} \mathrm{G}$ inda ${ }^{\prime} \mathrm{D}$ inci'u'k hidi God my Lord, my Lady, my Morning Star, this hömad go'k ba'ik tak'u'gumö'köt one two three fragments with

nanitaitumnö'i'puctur which I to thee have recited navaricda'dik·am which is health navarumni"'o'k· kuhi'di hö'madakamö'köt which is thy word. Then this creation with api'ctunha'gicda porki aniamai'cturda thou me wilt pardon because I not may fulfill höga na'varumhi'mda höga that which is thy way that navarumtồvorig höga napubö.'ima ${ }^{\prime} c$ which is thy length that which hither appears höga avemicmökor havaricda'dik·am that it very distant and it is health havaric·i'du'k·am ku.ha'bandör a'niamand it is treasure. Then with it from I not= pihöamtö'giD’a ${ }^{4} \quad$ kuhi'diöma'dakam.hök'öt anywhere you may see. ${ }^{4}$ Then this creation with adio's in. ${ }^{\circ} \mathrm{G}$ inda.'t inci'u'k. to God, my Lord, my Lady, my Morning Star. ha'pihö'van napimaringö"koraG In that place that ye are my manes amihövaN napimarda'dar'kam ictö'doG ${ }^{5}$ there that ye are sitters green ${ }^{5}$

${ }^{3}$ Cold and wind are conceived as health-giving and purifying, heat as synonymous with sickness.

${ }^{4}$ Possibly auditory error for -um-, THEE.

- The color appropriate to the east. 


\begin{tabular}{|c|c|}
\hline '"a'rwö'ta' & $\begin{array}{l}\text { höga } \\
\text { that }\end{array}$ \\
\hline 'hi' & $\begin{array}{r}\text { navarum.a } \\
\text { which is }\end{array}$ \\
\hline $\begin{array}{l}\text { a'bandör } \\
\text { here from }\end{array}$ & $\begin{array}{l}\text { nagamida } \cdot \text { dig nagamihi'kom } \\
\text { that comes health that it clouds }\end{array}$ \\
\hline Ö'pg & $\begin{array}{ll}\text { gövi' ha'ban'dör naB } \\
\text { htning } & \text { where from that }\end{array}$ \\
\hline mi & $\begin{array}{l}.{ }^{\cdot}{ }^{\prime} \text { rgida }^{2} \text { navari } \\
\text { ill be formed }\end{array}$ \\
\hline
\end{tabular}

o.hi hi'komö'k•öD gö'gö'r o.'hi beautiful cloud with great beautiful hi'komsa•'gid na•'puwö'pöga'ma.iwö•'cnia cloud between.

That advancing will start $\begin{array}{lcr}\text { na'puwa'tönö·ídida } & \text { va'viar }^{3} & \mathrm{o}^{\circ} \text { 'hi } \\ \text { that will go beholding } & \text { gray }^{3} & \text { beautiful }\end{array}$ tö'tvaGwö't·a napumai'vanio'k·ida ba'viar skies beneath. That hence already will go speaking gray

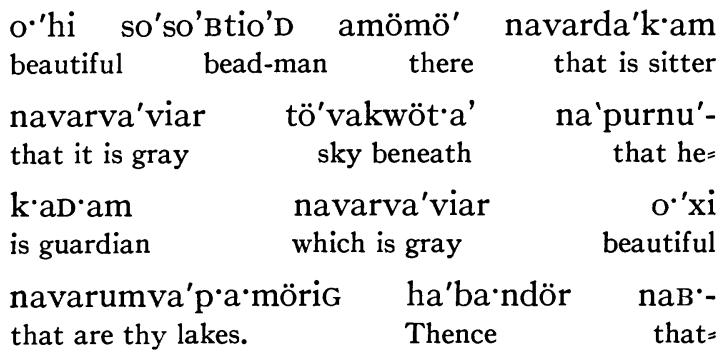

öixa.'duG ${ }^{4}$ na'puivi'ngi ku'.a'mömö"dör it hither . . that it . . Then there= from

napuivo'm•gia

that will arise

navargö"gö·r

which are great

na'puva 'tönờ·idida that already will go beholding

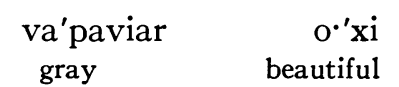

hi'kom.ör a'bimờ na'puvadu'via cloud within. There that already arrives

1 Possibly auditory error for -am-, your.

2 From here on, the references of the third person are doubtful. Most if not all of them probably refer to the journey of the Word, the prayer, the formula, through the heavens though some may have reference to the habitant spirits of the cardinal directions.

${ }^{3}$ Yellowish-gray, the color of the north.

na'puvam.a·'rgida gö'gör hikomsa·'giD that will be formed great cloud within. naB'ai'vatuda'giuna navaricda'dik·am That thou already wilt cleanse which is health navarumsa·'kumigö'köD ku.a'bimö'dör which is thy tears with. Then there from na'pumgókiptötugia navargö'gö· $r$ va'pavia·r that to both sides will look which are great gray xi'komsa'gi'D

na'pgamisá·ki'D’a cloud within. naB'ai'vada'giuna avarichö'pitkam that thou hither already wilt cleanse it is coldness navarumu'umihö'köD na'pgama.itwi·'cturda that it is thy ceremonial arrows with. That thou from us wilt chase away

navaricko'kdakam ci'k·o'r tö'tvaGwö'pta which is pestilence vicinity skies beneath navaricxö'p·itkam ka'va·r navarumwu'which is coldness chimal which is= p'uivas hö'köD anihö' napuvatönö'thy faces with. Hereabouts that already= idida aric·i'k•o’r na'va·rumtö'tvagiwö'pta will go beholding is vicinity which is thy skies= beneath

napuma.'r''gidida

that will be formed

navaricxö'pitkaM which is coldness hö'kia ma'mcim navarumxi'komagö'köD how many apparitions which is thy cloud with. na'puva'tönö·idida navarictu' $\mathrm{k}^{5} \quad \mathrm{o}^{\circ} \mathrm{xi}$ That already will go beholding which is black ${ }^{5}$ beautiful

navarumtö'tvagiwö' ta

which is thy skies beneath

giunid·a na'varichőp.itkam navarumu'"already wilt cleanse which is coldness which are= umi hö’kö napumai'vaniók·ida thy ceremonial arrows with. That hither already= will go speaking

4 These two stems evidently carry an esoteric ceremonial significance which has been forgotten by the present natives. None of the authorities interrogated was able to give a translation of them. They probably refer to various phases of the rain.

${ }^{5}$ The color of the west. 


\begin{tabular}{|c|c|c|}
\hline $\begin{array}{l}\text { ha''kic } \\
\text { tell }\end{array}$ & $\begin{array}{l}\text { u'vikam } \\
\text { womankind }\end{array}$ & $\begin{array}{l}\text { a'puarinda'D } \\
\text { who is my Lady. }\end{array}$ \\
\hline $\begin{array}{l}\text { arictu'G } \\
\text { Is black }\end{array}$ & $\begin{array}{l}0^{\circ} \times{ }^{\prime} \\
\text { beautiful }\end{array}$ & $\begin{array}{r}\text { tö'vaGwöt }{ }^{\prime} \text { 'v } \\
\text { sky beneath }\end{array}$ \\
\hline \multicolumn{2}{|c|}{$\begin{array}{l}\text { napur.da.'kam } \\
\text { that is sitter }\end{array}$} & $\begin{array}{l}\text { na purnu'k·ad aM } \\
\text { that she is guardian }\end{array}$ \\
\hline \multicolumn{2}{|c|}{$\begin{array}{l}\text { navarumba'pamörio } \\
\text { that are thy lakes }\end{array}$} & $\begin{array}{l}\text { naB } \cdot \text { ivo' }^{\prime} \\
\text { that thou= }\end{array}$ \\
\hline $\begin{array}{l}\text { migin } \\
\text { test }\end{array}$ & $\begin{array}{l}\text { navaricda'dik am } \\
\text { which is health }\end{array}$ & $\begin{array}{l}\text { navarumci'- } \\
\text { which is thy= }\end{array}$ \\
\hline $\begin{array}{l}\text { vordad } \\
\text { lumes. }\end{array}$ & $\begin{array}{l}\text { ha'ban'dö·r } \\
\text { Thence }\end{array}$ & $\begin{array}{l}\text { na'p·uio'hi } \\
\text { ecomes beautiful, }\end{array}$ \\
\hline $\begin{array}{l}\text { a } \cdot \text { iha'dug } \\
\text { at it . . ., }\end{array}$ & $\begin{array}{l}\text { ha'ban'dör } \\
\text { whence }\end{array}$ & $\begin{array}{l}\text { napuivi' } \eta \text { gi } \\
\text { that it . . . }\end{array}$ \\
\hline
\end{tabular}

naB'a'iD’a'giuna navarum·a'maR i'nimob That thou hither us wilt cleanse who are thy sons here na'tputuwo'inuG hi'di navaricda'dik'am that we wander this which is health navarum.ö'k·aD’a wö't·a kuB·ai'.iD·a'giuna which is thy shadow beneath. Then thou hither us= wilt cleanse

navaricda'dik·am which is health

navarumsa'kumgihö'köt which is thy sorrow with.

napgama.'it·ö'vörturda navarumgö'gu'cdara That thou for us wilt increase which is thy succor. ku.a'mi'dör na'pivo'mgia navarictu'tuk Then there from which will arise which are black navarumhi'komaG örhödör na'puva'tönö'which is thy cloud within from which already= idida navargö'gör o'xi xi'komờr willgo beholding whicharegreat beautiful cloud within naphö'kö'pa'.uma•'rgida Which with will be formed navarumxi'komaG·ö'kö't which is thy cloud with

nagamiwö'pgöv ha'ba·ndör which it lightnings whence navaricdadik $\cdot$ am which is health ha'ban'dờr whence a'bi.mödö·r napuga'miniók• na'pu.umhö'gid There from that speaks that to thee replies hödö·r navarumxi'komag.öra ku.a'bimödö·r alone which is thy cloud within. Then there from napumgo'kiptötu'gia that to both sides will look wilt cleanse navaricxö'p·itkam navarumu'umidö'köD which is coldness which are thy ceremonial arrows= with. na'p`uva'tönöidida

Which already will go beholding

that is thy skies beneath.

giuna navarichö'pitkam

wilt cleanse which is coldness

kumigö"köt navarci'k'o·r sorrow with which is vicinity

p'oiga'ba napubai'vaha'du'G vavi'ngi ha'ba'ndör nas'ai'vahi'komaG hither already . . . Thence which hither= already clouds up

umhi'komaksa''giD

thy cloud between

na'pgamiwöpgöv that thou sendest lightnings

naga'maictuma'ma'c that appear

navarumbo'poiga'ba which are thy paths in. navarumtö'tvagiwö't·a thy paths in. Which hither already . . . which= ku.a'miD॰ör napuma'vatönöidida aricta'1 Then there from that hence already will go beholding is white ${ }^{1}$

o'hi umtö'vagiwöta' a'ricta o.'hi beautiful thy sky beneath is white beautiful hi'komö'köD na'puwama''rgida napuma'cloud with that already will be formed. Which= ivanio'k·ida a'ricta' o.'hi so'so'Btio'D hence already will go speaking is white beautiful bead-man

a'ricta' o•'hi umtö'vagiwö'ta' napurdák·aM is white beautiful thy sky beneath that is sitter a'ricta' óhi so'so'B navaruma'toc'kardám is white beautiful bead which is thy seat on naparnúkad·am

which is guardian navarumba'p'amö·rit which are thy lakes.
ku.a'miD॰ör napivo'pmiD•a a'ricta' o॰'hi Then there from that thou wilt lift is white beautiful

navarumci'cwordad ha'ba'ndö'R na'puio'hi which are thy plumes whence that becomes= beautiful

1 The color of the south. 
ha'ba'ndör na'B'uida'di ku'ganavaricta' whence that thou healthenest. Then that which is= white

o'hi

beautiful

navarumci'cvoD

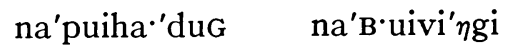

that it . . .

that it . . .

bandör na'puihi'komaG

whence that it clouds up

hi'komsa'giD cloud within

na'pgamiwö'p'göv

that thou sendest lightnings

a'ricta' o.'hi

is white beautiful

kuamömö'dör

Then there from

na'puva'tunơidida

that already will go beholding

hi'kom.ör

cloud within;

nagamictuma'ma·c which they appear

navarum·ai'niGdám

which is thy petate on.

napugo' kip.a'ptötúgia that in both sides wilt look

a'ricta'

o'hi is white beautiful

arictá·ta hi'komơ'kö't napuha'bandörbi.ivo'are white cloud with. That whence hither wilt=

pmikda navaricda'dik·am navarumu"umi raise which is health which are thy ceremonial= arrows

bai'vatuda'giuna aric'i'k·o'r navarumtö'hither already cleanse is vicinity which are=

tvagiwö't·a

na'pumờratönöi'dida thy skies beneath. That within will go beholding

a'rictumá'm

it is five tö'do green tövakwö't·a sky beneath

na'puhơ'köuma''rgida a'rictumá'm o.'hi that with will be formed is five beautiful navarumhi'komagö'kö't na'pamömödör which is thy cloud with.

napiwo'mgia a'rictumá'M navarumni'that will arise is five which is= $o \cdot k \cdot h o ̈ ' k o ̈ D$ napuba'vatunöidida aric· $i$ 'thy word with, that hither already will go beholding are=

vgo'k' o'hi tö'vagdam a'bi'mó seven beautiful sky on. There

na'puvadu'via

that already arrives speaking
na'varit.o.'G to'no.r hi'kom ci'vo't

cidúkam ha'ba'ndör na'gamida'diG

Fetish, whence that comes health

hö'kia ma'mcim hi'komö'köD

how many apparitions cloud with.

na'B·ida'giuna va'pa'viar o*'hi

That thou wilt cleanse gray beautiful

navarumu"umihö'kö'D ku.a'bimödör

which are thy ceremonial arrows with. Then there from

na'parda'k'am aric'i'vgo'k' o.'hi

that thou art sitter is seven beautiful

navaruma'tockardám naparnu'kaD·am

which is thy seat on that thou art guardian

aric·i'vgo'k• ó 'hi navarumva'p'amörig

are seven beautiful which are thy lakes

napivo'pmikda navaricdá dik·am

that thou wilt raise which is health

navarumci'cvordad aric·i'ko'r na.ima'-

which are thy plumes is vicinity which=

ma·c·i"a'rwö"ta va'varip. hu'r'nip.

appear east beneath ' north west

o'gipas ku.a'bimödör naB·iwö'pgöv

south. Then there from that it lightnings

na'gamistuma'ma'c arici'vgo'k' hi'kom.ör

that appear are seven cloud within.

a'bimödör na'pgaminio'k·ia napumhö'kda

There from that thou begin wilt speak that to= thee will reply

a'rici'ko•r tö'tvaGwö"ta ba'varip.

is vicinity skies beneath north

hu'r'nip. o'gipas a'ricivgo'k

west south are seven

hi'kom.ör naB·iku'G·ida na'varictumám

cloud within. That thou hither wilt go ceasing which are five

o'hi navarumni'o'k. kuhi'di

beautiful which is thy word. Then this

hö'ma'dakam hö'köD api'ctunha'gicda creation with thou me wilt pardon.

adio's in. $0^{\circ} \mathrm{G} \quad$ inda.'t inciu'k

To God my Lord my Lady my Morning= 


\section{NOTE}

This is the Perdon Mayor or principal prayer, it being the opening prayer of the most important of the four annual fiestas. After the patio has been prepared, the altar arranged and the fire lighted, the communicants arrive. Then, after darkness has set in, the Chief Singer takes his seat facing the altar to the east and recites the prayer.

This prayer must also be recited by one desiring to become a shaman in order to prove his knowledge and ability.

\section{TRANSLATION}

Oh my Lord, my Lady, my Morning Star! Hither have we come. Ye are my spirits who are seated there in the five heavens beneath the green east. From there will ye bring health.

With thy arrows thou wilt purify us; thou wilt quit from us the pestilence which surroundeth us beneath thy heavens. From there thou wilt lead thy path. Thou wilt cleanse us with the cold which is thy hand, with which thou wilt intensify for us thy spirit. Thou wilt lengthen for us thy way which thou wilt now cause us to tread, which is between thy altar. With these few fragments which I have recited unto thee thou wilt pardon me, God, my Lord, my Lady, my Morning Star, for they are thy Word which is health. With this formula thou wilt pardon me for I may not fulfill thy commandment, thy course which hither leadeth, for it is very far; it is health and treasure. Therefore I never may behold thee. So with this formula Hail! my Lord, my Lady, my Morning Star.

There are ye seated, my spirits, beneath the green east, on the beautiful green bead which is your throne, whence come health and the clouds, lightning and drizzle. There will it be created of the beautiful green cloud between the great beautiful clouds.

Forward will it proceed, observing beneath the beautiful gray heavens. Hence will go speaking the beautiful gray Bead-man who sitteth there beneath the gray heaven, the guardian of thy beautiful gray lakes. Then from there will it arise and go observing within the beautiful great gray cloud. Far away will it arrive where it will be formed within the great cloud. There wilt thou purify it with thy tears, which are health. Thence will it look to both sides, within the great gray clouds. Thou wilt weep and purify it with thy arrows which are the cold. Thou wilt quit from us the pestilence round about beneath thy heavens with the cold of thy chimal which is thy countenance. Here will it go about observing beneath thy heavens where it will be formed of the cold with thy many-colored cloud.

Then will it go about observing beneath thy beautiful black heavens where thou wilt cleanse it with the cold of thy arrows. Hither will come speaking and reciting the Woman who is my Lady. Beneath the beautiful black heaven is she sitting, guarding thy lakes whence thou drawest health, thy plumes. From them cometh beauty. Thou wilt cleanse us who are thy sons who wander here beneath thy healthful shadow. Thou wilt purify us with thy health-giving tears. Thou wilt increase for us thy succor. Thence will it arise from out thy black cloud and will go beholding within the beautiful great cloud. It will be created with thy healthful cloud whence come the lightning and the drizzle. From there he speaketh, answering thee within thy cloud, alone. Then will it look to both sides and thou wilt cleanse it with the cold of thy arrows. Round about beneath thy heavens will it gaze and thou wilt purify it with the cold of thy tears, round about in thy paths. From it thou sendeth the clouds and, within the cloud, thy lightning which appeareth in thy paths.

From there will it go beholding beneath thy beautiful white heaven where it will be formed of the beautiful white cloud. Hence will go speaking the beautiful white Bead- 
man who sitteth beneath thy beautiful white heaven on the beautiful white bead which is thy throne, guarding thy lakes. From these wilt thou raise thy beautiful white plumes whence come beauty and health. From thy beautiful white plumes cometh the rain; from them come the clouds and within thecloud thou sendest lightnings which flash on thy beautiful white carpet. From there will it look to both sides, gazing within the beautiful white cloud where it will be formed of the white cloud. From it thou wilt bring health and wilt cleanse with thy arrows, round about beneath thy heavens.

It will go about gazing beneath the five green heavens where it will be formed of thy five beautiful clouds. From there will it arise with thy five Words and will go about observing in the seven beautiful heavens. There will arrive speaking our Lord, the Sun, the Cloud, the Plume, the Cidukam from which cometh health in the many-colored cloud. With thy beautiful gray arrows wilt thou cleanse it. Thou art seated on thy seven beautiful thrones guarding thy seven beautiful lakes whence thou wilt raise thy health-giving plumes which appear round about beneath the east, the north, the west and the south. From there afar the lightnings flash through the seven clouds. From there thou wilt speak and they will reply unto thee from all around beneath the heavens, from north, west and south within the seven clouds. So wilt thou end thy five beautiful Words.

With this formula thou wilt forgive me. Hail! my Lord, my Lady, my Morning Star.

\section{TO CONCLUDE THE FIESTA \\ OF THE RAIN}

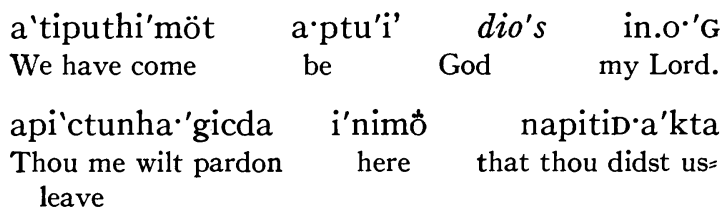
hi'd·i
navarictö'd·oG
um·ai'nigdam this that is green
thy petate on.

kuamömö'dör naB·ivo'pmigda hög·a Then there from that thou hither wilt raise that va.'viar óhi gamu"umi naphö"gray beautiful those thy ceremonial arrows which thou with=

kötitso'sbida hög·a navaricko'k'dakam us wilt go shielding that which is sickness arici'ko'r navarumtötvag.i ci"a·r is vicinity which are thy skies east wöt·a' ba'varip hu'rnip o'gipa beneath north west south a'ricivgo'k• $6 \cdot$ hi töt'vagdam kuamömö'dör are seven beautiful skies on. Then there from aB·aid·a'giuna thou hither us wilt cleanse na'varichö'pitkam which is coldness

na'varumno'v

na'pgama. $\cdot$ 'twi'cturda which is thy hand. That thou, beginning, from us= wilt repel

hö̀g:a navaricko'k'dakam xu'p $\quad$ ur that which is sickness wind ci'cvorig na't·unổn'ö' hidi plumes which fly this navarum·ai'nigdam a.möm•ödör There from which is thy petate on.

naB·ai.iD·a'g·id·a na 'varumgö'gu'cdara' that thou hither us wilt send which is thy succor na 'phòk•ötit•ö'vörtu·rda na'varum.which thou with to us wilt extend which is thy=

o' $\mathrm{rad} \cdot \mathrm{ak} \cdot \mathrm{am}$

inwardness.

\section{NOTE}

This prayer is recited by the Chief Singer at the close of the Rain Fiesta about dawn on the following day.

\section{TRANSLATION}

Oh God, my Lord! We have come where thou art. Thou wilt forgive me, thou who didst leave us here on this thy green carpet. From afar thou wilt raise thy beautiful gray arrows with which thou wilt shield us from sickness round about in thy heavens, beneath 
the east, the north, the west and the south in thy seven beautiful heavens. From there thou wilt purify us with the cold, which is in thy hand. Thou wilt cast from us the pestilence, the whirlwinds, the plumes which fly about on this thy carpet. From afar thou wilt send us thy succor and wilt reveal unto us thy spirit.

\section{TO PREPARE THE PATIO FOR THE FIESTA OF THE ELOTES ${ }^{1}$}

adiu's naparinsu'sbidat inci'u'k To God that thou art my Guide, my Morning Star, in.o.'G naparinda.'t ci"arwö't'ahö' my Lord. That thou art my Lady east beneath= there

napusoi"mácc

napitpubö.'inió• that thou sad appearest that thou didst hither speak napitpuböiwö'pgö amöhödör that thou didst hither send lightnings there from

napitpuböihíkmat ati'cumtá'n ha•'gicdara that thou didst hither send clouds. pardon

navarci'vgok ohi tötvaGwö't’a pixödör that are seven beautiful skies beneath where= from

napuböim.a'r'giD that thou hither art created. you beg

há·gicdara kupimi.'tuthá'gicda kupimi'.pardon that ye us will pardon, that ye us will= itma'kia lise'nsia kutsapi'ni.itu'kakda give permission that we here may pass the night kutkö·amdo•dicda höga navaramnöík•ar that we decorated for you may make that which is= your patio

para natpumci'cvoD $\mathrm{a}^{2}$ höga it.ö•'cig in order that we for thee ${ }^{2}$ may make plumes he our Corn

kut.i'ni.cia'dá'rsa gactökö.dam ci'du'okam that we here them may place that powerful fetishes

1 Nahua elotl, GREEN EAR OF CORN.

2 Possibly auditory error for -pu-am-, you.

3 On the musical bow. nampumtö'tök that they are called tapexte on

ganavaricta mai'nig.wö't'a kutsapi'that which is white petate beneath. Then we= putuasa'sa'uda $^{3}$ para natputuiákta ${ }^{4}$ say for them we will play ${ }^{3}$ in order that we may= bless ${ }^{4}$

para napucbai'k·a nat'uuh'gia in order that may be able that we may eat. kuti'puamci'cvoD‘a höganavarcivgok Then we for you will make plumes that which is seven amni'o'khököt para natpuam'a.'töD'a your word with in order that we you may cause= to know ganavarani' $\mathrm{o} \cdot \mathrm{k}$ that which is their word ganamaritgökorak they who are our manes wöpuhímdam nampuböit•ökdim gana'before gone on; that they hither us come extending that which,

varano'v para natpua'bantud'a'gimöt is their hand in order that we in it having= enfolded ourselves

gamtönöí.dida wöcorasa'"ва kuha'pu.pumay go beholding all hours in. Then so= $\begin{array}{lcr}\text { i'cöpata'n } & \text { ha'gicdara } & \text { wö'pu } \\ \text { also them beg } & \text { pardon } & \text { first }\end{array}$

höga navaritci'uk kuvipuböitnöídida he that he is our Morning Star. Then he hither us= will come beholding

pixổ nat'uha'nda pixö nat'ima ${ }^{\cdot}{ }^{\prime}{ }^{\prime}{ }^{\prime}{ }^{\prime} a^{5}$ where that we will meddle where that we will= go dawning 5

pixö' natitu'kakdida kuyamwhere that we will go passing the night that not= ha'ctuid·amhacumwa'da ickögököt anything over us anything will happen strong with aticia' $D \cdot$ ida $^{5} \quad$ kumipuböitnöídida we will arise. ${ }^{5} \quad$ Then they hither us will come beholding

4 By raising the ears of corn to the heavens.

${ }^{5}$ The stem $m a^{\cdot} c$ denotes APPEAR; the stem cia is evidently related to $c i^{\prime \prime} a \cdot r$, EAST. Both are used with the idea of ARISING AT SUNRISE, amanecer. 
ganamaritgö'korak

they who are our manes.

ti'cpuam’á·tud

we you give to know

hidi

this

konkihapögia-

With which thus only=

porki avi'a'mhacicbaíg

because not anyhow can that we you will cause= to know

ganavaramni' $\mathrm{o} \cdot \mathrm{k}$

that which is your word

navaramhi'mda

which it is your way

porkia'tiv iti'kradö'köt

putso'sbidim because we our filthiness with us go obstructing.

konki'.hapí itkaök kudiu'spöcambi'ak·a With which thus is; us hear. That God you will= sympathize.

\section{NOTE}

The Fiesta of Elotes or ripe ears of corn is held on September fifth. The Chief Singer arrives early in the evening and recites this prayer to the divinities to beg permission to prepare the patio for the fiesta.

\section{TRANSLATION}

Hail! my Guide, my Morning Star and my Father.

My Mother, who sadly appearest beneath the east, whence thou didst speak, sending thy lightnings and clouds, we crave thy forgiveness. Beneath the seven beautiful heavens thou wast created.

Continually do we implore you to forgive us and to give us leave to pass the night here, to array your court for you, to make you plumes of our Corn, and to place here the powerful cidudkam, as they are called, on their white cloth beneath their white carpet. We will play for them in worship, that we may be enabled to eat. Also will we make plumes for you with your seven words, that we may teach you the Word of our spirits who have gone before. They come reaching unto us their hand that we, enfolding ourselves in it, may go beholding in all hours.

Likewise do we beg forgiveness first of Him who is our Morning Star. He will come to watch over us where we perform, where we pass the night and rise with the dawn, so that no ill may befall us and we may arise with strength. Our spirits will come to watch over us.

Only this fragment do we say unto you, for we may not teach you more of your Word, which is your Way, for we are confused by our sinfulness. This, no more. Hear us! May God bless you.

\section{TO COMMENCE THE FIESTA OF THE ELOTES}

adio's na'par.ine.' $\mathrm{k}$ tunha'gicid To God, that thou art my Father. Me pardon hi'di hömaD gok: ba'ik ni'.o'k'hök'öt' this one two three word with. tunha'gicid porke na'naric.i'kra'k·am Me pardon because that I am vile hö̀g•ahököD a'nicponsó'Bdim gờkö that with I myself obstructing. Therefore nipumtán hágicdara ku·pi'am.ago'I thee beg pardon. Then thou not in two= kiptönö'nöik·da' places wilt look. picina'ptunda'gia ${ }^{1}$ Thou in me me wilt seize ${ }^{1}$ namarit.gö'korak vöpöhímdam na'pu.pui' that they are our manes before go on. Thus= cồ'p pi'miambi'ak'a napimarapim also ye not will need that ye are ye pimia 'm.soi'umö'rid·a ye not sad selves will feel.

pi'micböintö'kda hög•a navaramno'v para nan.that which is your hand in order that $\mathrm{I}=$ a'ptunda'gia para nanickö'k'.hök'öD.in it me will seize in order that I happy with= ima•'cdida ga'gurahö'van pimi.iu''rnida will go appearing. Aside there ye will go casting gacto'nkam höga navaramu"umi hö'ga that heat that which are your ceremonial arrows that

navaramkávarakhö'köD pi 'mi.potso'sbidim which are your chimales with ye us go protecting

${ }^{1}$ If correctly given, this form is inexplicable. 
bö‘c

all ci'ko'rhö̀van

vicinity there högacto'nkam that heat.

ku'pigama.iwa'hida

Then thou wilt go repulsing

natpöiD·ám.hagö'i gö'kö

that it did us over already fall. Therefore I thee= beg

ha''gicdara pia'mbi'ak'a pardon. Thou not wilt need self wilt feel.

apica 'p'tumda'gia

Thou in them thyself wilt seize manes

amöhö̉dör

there from

namitpöböiwöp'gö

that they did hither lighten

höga

that

tö'vakwö't’a

navarci'a'r

sky beneath.

That is east

natpöva'nio ha'va

that did already speak and already reply

ba`'baripkam natpöwa'nio havahö'rnip North. That he did already speak and west natpö'vahök höga hu'huktio'D that did already reply that Pine-Man na'tpu.böa'hök ha'pu natpöva'p'nio that did hither already reply. Thus that did already again speak

natpöbö.a.'hök hö'ga' o'gipa anihövvan that did hither already reply that south. There tum·a"agdimuk cíkor'hövan hi'di hence already gone conversing vicinity there this hö'köD namitpöva'nio ci'vgo'k• with that they did already speak, seven tö'tvagdam natpuvák·u'gat skies on that did already arrive.

\section{TRANSLATION}

Hail! thou who art my Father. Pardon me these few words; forgive me them. For I am vile and therefore do I obstruct myself. Therefore do I beg thy forgiveness. Look not askance; thou must be possessed of our spirits who have gone before.
And ye who are ye, do not feel sad. Ye will reach unto me your hand that I may be held in it and arise with gladness. With your arrows will ye cast aside the heat; with your chimales will ye shield us from it, round about.

Thou wilt repel the heat that has fallen upon us. Therefore do I beg thy forgiveness. Be not sad. Thou must be gathered unto them who are our spirits who from afar send the clouds and the lightnings beneath the great heaven.

From the east he spoke and He of the North replied. He spoke and the West replied, replied the Pine-Man. Again he spoke and the South replied. And so did each in turn repeat the word they had spoken till it came unto the seven heavens.

\section{TO CONCLUDE THE FIESTA OF THE ELOTES}

adiu's naparin. ${ }^{\cdot{ }^{\prime} \mathrm{G}}$ naparinci'u'k To God that thou art my Lord, that thou= art my Morning Star,

insu'sbidat ati'cpuböhímöD puctuga' $\mathrm{i} \cdot \mathrm{M}$ my Guide. We hither came desirous of roasting hi'dimnöi'kar·dá'm böc na'tpuin.da'r·im this thy patio on all that we here are sitting navarumnöi"kardám pihövan na'that is thy patio on where that=

pitpuda·íwak' sa'sa·kic navarumo'k thou didst, having sat down weep for him who is= thy Lord,

na'varumda't $\quad$ ci'"arwö't'ahö' napuwho is thy Lady, east beneath there that= a'rgidic pixö' napuká·t' ganavarumhávul is created, where that is hung that which is= thy jicara

böc umu'umihök'ö't umka'kvarhöku'D all thy ceremonial arrows with thy chimales with

${ }^{1}$ A cup or bowl made from a gourd and generally decorated with beads impressed in wax. 
navaricta'm·ai'niGwöt'a navaric $\cdot i^{\prime} k m a t k a ́ \cdot t^{\prime}$ which is white thy petate beneath which is cloudy= overspread

\begin{tabular}{|c|c|}
\hline $\begin{array}{l}\text { napucva"u·taG } \\
\text { which drizzles }\end{array}$ & $\begin{array}{l}\text { napucbi''gikam } \\
\text { which } \cdot \cdot \cdot \cdot\end{array}$ \\
\hline $\begin{array}{l}\text { napui.vu'sandim } \\
\text { that arises }\end{array}$ & $\begin{array}{l}\text { ganavarhi'ko'm } \\
\text { t which is cloud }\end{array}$ \\
\hline
\end{tabular}

vgok o'hi tö'tvaGwö't’a amuhö'dör are seven beautiful skies beneath. There= from

napubö'inio'k·im

that hither comes speaking

napuböiva"u·taG that hither drizzles.

amuhödör napuvackaít·im hö'ga

There from she

navarmárad natpubö'ihó $t^{\prime}$ ga.o'gaD who is his daughter that he did hither send he,= her father

hidi navarictödoG

this that is green

napuica 'picda'tpam·ác

that it well clean appears.

mai'niGdá $\cdot m$ petate on

natpui'nimöhö'That she did here=

vadúvia· hidi nöíkargiD’ám böchök·u't already arrive this his patio on all with

hacnapuci'dúdu ci'korhúwan puva.'o·imö thus that hoards vicinity there already walked pihö'dör natpubö'ixo't gaó'gat where from that he did hither send that her= father.

kuna'tpunö'vadu'via· hidi nöíkargid’ám Then she did here already arrive this his patio on sá·kimöG ganavarci'vgok o.'hi having wept they which are seven beautiful tö'tvakwoòt'a ba'bariB hu'r'niB skies beneath north west o''gipa ci'arwöt'a pixödör south east beneath where from $\begin{array}{lcr}\text { natpuböiho' } t^{\prime} & \text { gao'gad } & \text { para } \\ \text { that he did hither send } & \text { he her father } & \text { in order }\end{array}$

${ }^{1}$ This form is impossible; the future suffix is probably superfluous. na'puini.ma." Riat hidi nöi'kargid’ám that she here should appear this his patio on. kuna'titpua'bö·i para nat.ivo'migda So we did already take up in order that we will lift natpuva.a'r'gi(dida) ${ }^{1} \quad$ ha 'cnacidúdu that he did already (will) ${ }^{1}$ create thus that hoards ci'k·orhúwan vicinity in napurnöí'kargid’ám that is his patio on puva'tồ ganavarictödok ba't’ogid’ám already placed that which is green his tapuxte on pixő napua.'r'gidic natitpuva'ga'í where that creates that we did already roast natitpuva'hu' kuvictuthá'gicda ganavaróthat we did already eat. Then us will pardon he= gat ganavardö.ut wö॰c isa'who is her father she who is her mother all her=

sakumgidökö't pihö' natpumáccir tears with where that she did appear.

natpuva'nu' $\mathrm{k}^{\prime} \quad a^{\prime}$ sta kwiya'mivo'miGda ${ }^{2}$ That she did already guard until that not= will raise. ${ }^{2}$

$k u^{\prime} n k i$ hapi nicpum·át·ud konkidio's With which thus I thee give to know. With= which God

pïcumbi'ak·a

for thee will feel.

\section{TRANSLATION}

Hail! thou who art my Lord, my Morning Star and my Guide. Hither did we come to roast in this thy court, all of us who here are seated in thy court. There thou didst seat thyself and didst cry unto Him who is thy Lord and thy Lady who was created beneath the east. There is hung thy jicara with all thy arrows and thy chimales beneath thy white carpet o'erspread with drizzly clouds. There ariseth the cloud whence came the lightnings and the voice beneath the seven beautiful heavens. Thence it cometh speaking and drizzling.

${ }^{2}$ Probably a direct translation of the Spanish idiom hasta que no in the sense of UNTIL. 
From afar cometh hearkening she who is his daughter whom he, her father, did send to this green carpet, beautifully clean. Here she arrived in this his court with every adornment that belongeth to her, having journeyed from whence her father sent her. At last she came, weeping, unto this his court, beneath the seven beautiful heavens, beneath the north, the west, the south and the east. From there did her father send her that she might appear in this his court.

Therefore did we grasp her to raise up her who was created round about; laying her on her green cloth in her court, where she was created, we did roast and eat her. Therefore will $\mathrm{He}$ who is her father and her mother forgive us because of all her tears. There did she appear and wait until we should raise her up.

Thus do I give thee to know. May God have mercy on thee.

\section{TO PREPARE THE PATIO FOR THE FIESTA OF THE PINOLE}

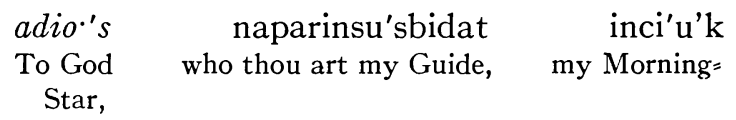

in. ${ }^{\circ} \mathrm{G}$ inda ${ }^{\prime} \mathrm{D}$ anihö napimpuda'dar my Lord, my Lady. There that ye are seated ci'ko'r ganavarica'p.ma.'cim am.a'vicinity that which is well appearing your= tockardá'm navarictödog kuha'pu.seat on that is green. Then thus= $\begin{array}{lrr}\text { puicö•B } & \text { nicamtan } & \text { ha.'gicdara } \\ \text { also } & \text { I you beg } & \text { pardon }\end{array}$ $\begin{array}{cccc}\text { napimitunha' } \text { gicda } & \text { hidi } & \text { hömat } & \text { gok } \\ \text { that ye me will pardon } & \text { this } & \text { one } & \text { two }\end{array}$ vaik ni'o'khököt navartakugamhököt three word with which is fragment with porki aniamha'cicba‘ík nanam‘átoD`a because I not any can that I you will cause to= know

${ }^{1}$ Nahua pinolli, PULVERIzed CORN-MEAL. ganavaramni.'o•k höga navaramtótnorik that which is your word that which are your= suns.

kunsapi 'tuwó`cka hídi navarictödo Then I say will sweep this which is green amnöíkardá'm para nansapi'ni.i 'your patio on in order that I say here= citu'kakda nanpu.i'ni.tuna.'da will pass the night that I here will make fire navaramnöíkardá'm para nan.i'ni.adá'rsa that is your patio on in order that I here them will= place

höga ciduokam nampumtötök hidi that idols that they are named this navaricta' ava't’o.dám navaricta' that is white their tapexte on that is white amainiGwöt·a ganavarau"umihököt höga their petate beneath. That which are their ceremonial arrows with that

navaraka'k'varak pihö' nampuököditso'that are their chimales where that they with us= sbidim anihö wöc ikorhövan go protecting there all vicinity there. kuti'puama·'töD·a kutsapi'pumiwá $\mathrm{G}$ höga Then we them will cause to know that we say hence= scatter that

navaratui'spi ${ }^{1}$ which is their pinole ${ }^{1} \quad$ which is their atole. ${ }^{2}$

kuti.ini.pücitö'kia hidi navaraha'vu•öra Then we here will place this which is their= jicara within.

kuticpu.ama't·ut

ganamaritgökorak Then we them cause to know they who are our manes wồpuhi·'mdam anihö' nampuda'dar before go on there that they are seated nampuböitnöíD wöcorasa'ba that they hither us watch all hours in nampuböit'ö'k·it höganavarano'v that they hither us extend that which is their hand natpwa'ban.tuD·a'gimöt gamtönöídim that we in it having wrapped ourselves going observing

${ }^{2}$ Nahua atolli, PINOLE MIXed with WATER AS A GRUEL. 
wöcorasaB·a

kuti'cpuatán all hours in. ha.'gicdara pardon $\begin{array}{lcr}\text { ganavarinsusbidat } & \text { inci'uk } & \text { ino.'k } \\ \text { she who is my Guide, } & \text { my Morning Star, my Lord, }\end{array}$ inda.'D kumi'puma.'töhi my Lady. Then they shall know.

itka'ök Us hear!

kumitutha'gicda konkidio'spöcambi'ak'a Then they us will pardon. With which God you will= sympathize.

\section{NOTE}

This prayer is spoken by the Chief Singer upon arriving at the ceremonial patio early in the evening of the fifth of January in order to beg permission of the divinities to prepare the patio for the Fiesta of the Pinole to be held that night.

\section{TRANSLATION}

Hail! my Guide, my Morning Star, my Lord and my Lady who are seated round about on your pleasant green throne. I beseech you, forgive me these few words, this fragment, for I may not teach you your word, which is your days. I will sweep this your green court that I may pass the night here, that I may kindle fire here in your court and place here the Cidudkam, as they are called, on this their white cloth beneath their white carpet. With their arrows and their chimales do they protect us in all parts. We say unto them that we will scatter about their pinole and their atole, and will place them here in this their jicara.

Also do we implore our spirits who have gone before, there where they are seated, watching us in all hours, that they reach unto us their hand that we, wrapping ourselves in it, may go beholding in all hours.

Also do we beg forgiveness of my Guide, my Morning Star, my Lord and my Lady. So may they know. Hear us and forgive us! May God grant you his mercy.

\section{TO COMMENCE THE FIESTA OF THE PINOLE}

napimarinháha'cdun anihönapimtuda'da·r That ye are my relations there that ye are seated. kupi'miambi'ak'a hactudö'kö't' napimsoi'Then ye not will feel anything with that ye= um'ö'rid‘a höga amömödö·r höga sad will feel. $\mathrm{He}$ there from that dio's itq.' $\mathrm{k}$ iD.a.'t avipuböiamGod our Lord, our Lady he hither you= da'giuna hög·a navaricxö'pitkam will cleanse that which is coldness navaramu"umihököD kumgama.iamwhich are your ceremonial arrows with. Then they= wi'cturda höga navaricko"dakam you will quit that which is sickness ga"gurahu'van nagamau'rna mökörhö'aside there that he will raise distant= van kuviambiha'k'tu'rda ha 'ciD'u'nia within. Then not hither will finish any us will= happen

hi'd·itu'ki·pságid i'nimö natitpubaivathis night within here that we did hither= da'ra·iwa hi'di navarictö'd'o o॰'hi already seat ourselves this that it is green beautiful

navaranöíkardam höga namaritgökoraG which is their patio that that they are our= manes.

kuxa'cumdúk·aDhö'köD ku.a'mumödö·r Then any happening with. Then there from amatö'vö'r'turd $\cdot{ }^{1} \quad$ gu'gucdara da' di they for them ${ }^{1}$ will lengthen succor health hi'ko'm natxök'ö'gamtötu'gia ku'hi'di cloud that we with will see. Then this hö'mad·akamö'k•ö a'pimi'ctunha'gicda creation with ye me will pardon napimarinháha'cdun napimitci'va.umtá't that ye are my relations. That ye did tired yourselves feel

amumödör

there from

napimitso'soigim that ye did sadly go

${ }^{1}$ Possibly should be amit-, FOR US. 
napimitacihu't'ua

that ye did stumble selves pain.

pero högaköt
But that with
think.

kugamumö'dö·r

Then they there from

a'migama.itwi ''cturda

they from us will quit

navaricda'di $\mathrm{ka} \mathrm{ka}^{\prime} \mathrm{v} \cdot \mathrm{r}$

that is health. Chimal

namhö'kötso'sbi'da

that they with will shield

$\begin{array}{lr}\text { ci"a.rwö"ta } & \text { va'varip } \\ \text { east beneath } & \text { north }\end{array}$

navaricko" $k \cdot d a k a m$ that is sickness

hu'r'nip

west

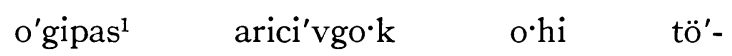
south ${ }^{1}$ are seven beautiful skies=

tvagdam ku.a'bimödör amiböimu'mgiad’a

on. Then there from they hither will bend

hög·a na'va·raci'cvod`aD namhök•ö'itxö'that that they are their plumes that they with=

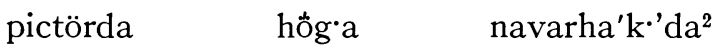
for us will chill that which is complete. ${ }^{2}$ kuhidi'kö'D pimictunha'gicda ku'n'Then this with ye me will pardon. Then I= i'nimö.ha'pu.am·a'tud napimarinha'ha'cdun here thus you give to know that ye are my relations. $d i o^{\prime} s$ pïcambi'ak·a

God for you will feel.

\section{NOTE}

This prayer is addressed by the Chief Singer to the communicants assembled to celebrate the Fiesta of the Pinole, or corn meal, at the beginning of the ceremony.

\section{TRANSLATION}

Ye are my brethren who are seated here. Ye need on no account feel sad. For God who is our Father and our Mother will purify you from afar with your arrows, which are

${ }^{1}$ Eleno gave o'gipa; Rito insisted that o'gipas was correct. the cold. They will cast from you the pestilence which he will put far aside. No harm will come unto us this night while we are seated here in this beautiful green court of our spirits. From afar they, will send us increased succor, health and clouds, that with their help we may behold.

Ye will pardon me this formula, my brethren. Ye have tired yourselves on your sad way hither; ye have stumbled and hurt yourselves. But do not on that account apprehend anything. Our spirits will protect us; they will bring health. With the chimal, which is their faces, will they shield us from sickness beneath the east, the north, the west and the south in the seven beautiful heavens. From there will they bend hither their plumes with which they will chill us.

With this ye will pardon me. Thus do I say unto you, my brethren. May God bless you.

\section{TO CONCLUDE THE FIESTA OF THE PINOLE}

adiu's ino.'G inci'u'k tunha.'gicid To God, my Father, my Morning Star. Me= pardon.

a'tivatsapi 'cpuinda" $r \cdot i m$

amtánimöt We, we say here seating ourselves you begging ha'gicdara porki titi'ma"wa gatui'sap pardon because we did hence already scatter that pinole.

kuti'cpuama.'tud bö·cir natpuindádar Then we you cause to know all that we here are= seated

nati'tpua'.má·cid hidi tukasá'git that we did already appear this night within natitupui'niva.dára·iwa ti'cputö'maiamthat we did here already seat ourselves. We continu= sá·kcit napimargö'gur·kam ci'dú·Dkam ally you weep that ye are greatnesses fetishes na'pimumtötöG that ye are named. kuha'pu.pui'cö·p Then thus also

${ }^{2}$ Difficult to translate. 
ti'camtán há·gicdara kuvia'mid·am.tuờka we you beg pardon that not us over= will happen.

ku'ganavaramu"umihök•ö pimitso'sbidida Then that which are your ceremonial arrows with ye= us will go shielding

hö'ga navaricko'k·dakam wöcorasa'ba that which is sickness all hours in icxö'pitkamök·ö'D pi'mid·a·'giunid'a coldness with ye us will go cleansing.

kuga"gurahöwan

Then aside towards api'minö'niD`a ye will cause to fly

gactónkam kuha'pu.pui'cőp ati'cumta'nim the heat. Then thus also we thee go begging

há'gicdara na'paritám.itci'u'G na'pu.o•ídak pardon who thou art our yellow, our Morning Star that thou belongest

ci'arwö't·ahö'van

east beneath there

na'pitpubö'iwöp'gö lightnings

na'pitpubö'ihi'kmaD that thou didst hither send=

that thou didst hither send clouds hither speak

na'pitpubö'it·ök

that thou didst hither us extend hand.

napitpuböin·ió that thou didst $=$

hö'ganavarumnóv that which is thy

kuha'ctu.gö'kamö'k•ö’t kuvia'mid·amha'cThen anything greatness with. Then not over us=

tuacumwáda kutiti'ctó'nimör.ba'cituháha ${ }^{1}$ anything will happen. Then we did suddenly already make izquite. $^{1}$

kutiti'puma'vwá höga a a 'rak.úv
Then we did hence already scatter that child=
female navarum•ár na'pitpuböida'ktá hidi which is thy daughter that thou didst hither send this

oi'dadám kugởku.ti'pumtán ha•'gicdara world on. Then on this account we thee beg pardon

na'varci'vgók

that are seven

óxi beautiful

tö·tvak.wồt:a skies beneath

na'pua.'rgidic

that thou art created. ourselves

\section{kutiti'cpuböidáraiwa}

Then we did hither seat= navaric.hi'dictö"do

that is this green

itha'pu.hök·ö

our jicara with

itvá·m·uit

our atole.

ganavaramhí·mda

that which is your way

your patio on

vö $c$ all

navaramtótnorik kutiti'cto"nimör.ba"cituhá that which is your suns. Then we did suddenly already make izquite

hidi amnöi'kardám kuticpuamtánim this your patio on. Then we you go begging ha.'gicdara hidi navarci'vgok pardon this which is seven ni.'o·k·hö'kö't na'pitpubö'idak'ta word with. That thou didst hither leave ganavarum’ár na'pitpubö'inió ci'vgok she who is thy daughter that thou didst hither= speak seven

ni'o $k$ 'hököt na'pitpubö'ihó't hidi word with that thou didst hither send this navarictö'do amai'niGdám navaricapthat is green your petate on that is beautiful= má·cim.ká't na'varichi'komak navaricappearing, outspread, that is overclouded that is* va"utak navarichi'kmat.ká·t kuha'pu.ö·p drizzly that is beclouded, outspread. Then thus also ati'camátut ku'nkiha'p.í inka'ök we you cause to know. With which thus is. Me hear naparino.'G naparinda.'t naparinsu'"who thou art my Father, who thou art my Lady, who thou art my=

sbidat inci'u'k kunkidios pöcumbi'aka Guide, my Morning Star. With which God thee feel.

\section{TRANSLATION}

Hail! my Lord and my Morning Star. Forgive me. Seating ourselves, we beg your forgiveness, for we have scattered the pinole. We give you to know, all of us who here are seated, that we have this night appeared here and seated ourselves.

2 The "flower" signifies peyote, Nahua peyotl, Echinocactus or Lophophora Williamsii.

\footnotetext{
${ }^{1}$ Nahua izquitl, TOASTED CORN.
} 
Continually do we beseech you, ye who are called the powerful Cidudkam. Likewise do we beg your forgiveness, that no ill may befall us. With your arrows will ye cast from us all sickness and in all hours will ye purify us with the cold. Ye will put to flight the heat.

Likewise do we beg thy forgiveness, our Golden Morning Star who belongest beneath the east, whence thou didst send the lightnings and the clouds, whence thou didst speak and didst reach unto us thy hand with magnitude. Therefore no ill will befall us because, unbidden, we have toasted izquite. We have scattered the maiden who is thy daughter whom thou didst send to this world. Therefore do we beg thy forgiveness, who wast created beneath the seven beautiful heavens.

We have seated ourselves in this your green court with our jicaras and our peyote and our atole. Ye will not interrupt your way, your word, your days because, unbidden, we have toasted izquite in this your court. Therefore do we beg your forgiveness with these seven words.

Here thou didst leave thy child. Speaking the seven words thou didst send her to this thy green carpet, beautifully outspread, overcast with drizzly clouds.

Likewise do we give you to know.

So be it! Hear me! thou who art my Father, my Mother, my Guide and Morning Star. May God bless thee.

\section{TO PREPARE THE PATIO FOR THE FIESTA OF THE MILPA CUATA ${ }^{1}$}

adiu's naparinsu'sbidat

To God that thou art my Guide, my Morning=Star, ino'' $\mathrm{k}$ indat anihö' napimpudadar my Father, my Mother, there that ye are= seated

${ }^{1}$ Nahua milpa properly signifies a cornfield; among the Tepecanos it connotes the growing corn plant. Nahua cuate means "twin;" Tepecano changes it to cuata to agree with milpa. cikorhö'van ganavarictödó ama'tockardám surroundings in that which is green your seat on. kupimitutmakia lisensia kutpuThen ye us will give permission that we= i'nicituha.'na para natkö'tudo'da hidi here will handle in order that we decorated= will make this

navaramnöíkardám para natsapuka·iya which is your patio on in order that we may= hear

$\begin{array}{llrr}\text { höga } & \text { ni'ok·iD } & \text { höga } & \mathrm{O}^{\cdot \mathbf{B}^{2}} \\ \text { that } & \text { his word } & \text { that } & \text { stranger }^{2}\end{array}$ that napumöhödöra.umá.gim ci'arwö'tahödör that he afar from already comes conversing east= beneath from.

kutsapi'pu.ininöra hidi töho'v pixö' Then we say here will await this cave where namiamit•ögia hidi navarictútu $k$ that they not us will see this that are dark u'u'c.ör ${ }^{3} \quad$ para natpugamiká.hida mountains ${ }^{3}$ within in order that we may go= hearing

ganio'k·it kuvipumöhödörva"umágim that his word. Then he there from already comes= reminding

pixödör natpuböiho't ganavarógat whence that he did hither send he who is his= father

navardö.öt para napu.intam.soiwho is his mother in order that he here sadly=

'má·cka initságit napuitkumpa·'niarad·a should appear here us between that he us should= accompany

pixő napusoi'má·cka itvö·m where that he sadly should appear us with. kupumöhödörva'hi·m puböa'nio Then he there from already comes hither already= spoke

böawöp’gö wö‘c kötui'kamököt hither already lightened all decorations with wöc·i'cvoDgiD`ököt hacnapua'r'gidic all his plumes with. Thus as he forms

2 This is the term applied to the Mexican neighbors.

${ }^{3}$ Montañas, WOODED HILls; $u \cdot c$ signifies TREe. 
napuca'pma·'cim that good appearing

kötui'k·am

decoration

bö·him comes

tö’idököt garb with

pumöhödörva'thence already=

that which is green

umágim wöc·i'korhövan

hacnapuci'dúdu goes counselling all surroundings thus that hoards. kuti'puköDún'ahi para natpunö·ra Then we decorated ourselves will make in order that we will await

hi'di navarnöíkarad'am kuvi'puböi-
this that is his patio on.
du'via para natsap'ukaíya ganio'kit
arrives in order that we may hear that
his word,

para natpunöída para natputötgicdá in order that we may see, in order that we= may repeat

höga nio'kit $\begin{gathered}\text { para } \\ \text { natpuhínkoida } \\ \text { that his word, } \\ \text { in order } \\ \text { him, }\end{gathered}$ para natpumáttöD·a navaro'gat in order that we may give him to know who is= his father

$\begin{array}{lcc}\text { navardö.öt } & \text { natpuböiho't } & \text { hidi } \\ \text { who is his mother } & \text { that he did hither send } & \text { this }\end{array}$

\begin{tabular}{|c|c|c|}
\hline $\begin{array}{l}\text { oi'dadám } \\
\text { world on } \\
\text { will }\end{array}$ & $\begin{array}{l}\text { para } \\
\text { in order }\end{array}$ & $\begin{array}{l}\text { napurit } \mathrm{u}^{\prime} \mathrm{kuka}^{1} \\
\text { that he be our flesh }\end{array}$ \\
\hline
\end{tabular}

para natpuököt.gamtönöíd·a hidi

in order that we with may go seeing this

oi'da.dám konkimi'puma'töhi inka'ök world on. With which they shall know it. Me hear

ganamaringökorak

they which are my spirits

$\begin{array}{lcr}\text { kuhapu.puicồ'p } & \text { nicata'n } & \text { hagicdara } \\ \text { Then thus also } & \text { I them beg } & \text { pardon. }\end{array}$

konkidiospöcambi'ak'a

With which God you feel.

\section{NOTE}

The Fiesta of the Milpa Cuata, celebrated on the fifth of March, is rather variant from

\footnotetext{
${ }^{1}$ The flesh of our bodies.
}

the other three fiestas. It is held in a cave or rock shelter and is quite different from the others in type. As before, the Chief Singer arrives early in the evening before the others and recites this prayer to the divinities to beg permission to prepare the dance patio for the celebration of the fiesta.

The Milpa Cuata is any corn plant which grows with a forked stalk and an ear on either branch. It probably has an intimate connection with the horns of the deer. At harvest time the forked stalks are garnered with a special prayer (no. 29). They are then bound in a sheaf and preserved until this fiesta.

\section{TRANSLATION}

Hail! my Guide, my Morning Star, my Father and my Mother, seated round about on your green throne. Ye will give us leave to work here, to adorn this your court that we may hear the words of the stranger who from afar cometh counselling from beneath the east. Here will we await him in this cave among the dark forests where the neighbors will not behold us, that we may hear his word. He cometh counselling from afar whence his Father and his Mother did send him mournfully to appear here among us and accompany us. Already he cometh; he hath spoken in the lightnings with all his adornment, with all his plumes. He cometh arrayed in his glorious green garb with which he was created, counselling on every side.

Therefore will we adorn ourselves to wait for him in this his court. Here he will arrive that we may hear his word, that we may behold him, that we may repeat his words and that we may cry unto him. We will say unto Him who is his Father and his Mother that he did send him to this world to be our flesh, that we might go beholding in this world.

Thus shall they know it. May my spirits who have gone before give ear unto me. Likewise do I beseech them. May God bless you. 
II. TO COMMENCE THE FIESTA OF THE MILPA CUATA

$a \cdot d i u^{\prime}$

To God, in. $0^{\circ} \mathrm{G}$

inci'u'G

my Morning Star.

my Lord,

tu'tha'gicid

Us pardon

hö'mat go*k

two

one

napimaritgö'koraG

that ye are our spirits

vö co'rasa"'Ba

nati'má cdim

napimitNöídim

that ye us go beholding

all hours in.

That we go appearing

pihö'-

natihúru'ndim ${ }^{1}$

that we go retiring 1

napimitnö•í.dim that ye us go beholding

vöcorasa'ва

all hours in.

napimaritgö"korak

That ye are our spirits

pi 'miambi'a'ka'

ye not will feel

pihöna 'pimago'kiptunö'where that ye to both sides=

nöikda

ku'pimi 'ctutha.'gicda

pihö'-

will look.

Then ye us will pardon

where =

natitúkagdim pihö'naticía'dim na'pimwe go passing the night

dawning

that $y e=$

wherever that we go=

itnú $\cdot k a D \cdot a$

na'pimaritgö'koraG

kupi'm-

us will guard

that ye are our spirits.

Then ye=

iamgo 'kiptunönöik'da'

kuti'camta'nim not to both sides will look.

Then we you go begging

ha."gicdara'

pardon aside

ga"'gurhá'

pinöniD·a

höganavarictón'kam

that which is heat

where will cause to fly

pinat.a'tiviamóipö

where that we we not walk.

ku'pimicbö'.ituda'"giuna ichö•'pitkamök·•öD'

Then ye hither us will cleanse coldness with.

ku'pimi'nờ'nid'a

mö·khá"

hö'ga-

Then ye will cause to fly distant that $=$

navarictón'kam

which is heat.

ku'pimicbö'ituda.'giuna kupimicnöniD·a mö•khá' va'p·a·viar Then ye will cause to fly distant gray u'umi.hö'k'ö' ceremonial arrows with pinat.a'tiviamóipö where that we, we not walk WEST.

na'varamka'va·rigö'kö'D napimbö'.ituso.' that which are your chimales with that ye hither= sbidim höganavarickó'kdakam kuus go shielding that which is sickness. Then= ga'gura.hö'vinổn·id·a ku'viamha'ctu.iD’aside will cause to fly. Then not anything us=

ám.ha'ctua'cumwáda ati'puta·ním háover anything will occur. We go begging par= gicdara hö'ganavaritsu'sBidat itcíu'G don he who is our Guide, our Morning Star, navarit. $\sigma^{\circ} \mathrm{G}$

na'pubö'it·ơk'dim who is our Father that he hither us comes extending ganavarnóvit

that which is his hand go seizing

para nagama'itwíc'turda höga in order that he for us will go repulsing that navarickó'kdakam ha'pu'pïcồp tictá·nim which is sickness. Thus also we go begging há'gicdara hö'ga navarid’át pardon she who is our Lady wadalu'pi pihö̀ napuaptu'i' Guadalupe where that she is

hö'ganavaricta'híko'm.sá'git örxöva·n that which is white cloud within, within there napua''rgidic höga navarci'vgo $\mathrm{k}$ that she forms. That which is seven

o'xi tö̀tvak.dám pihö'napusoi'.mácc beautiful skies on where that she sad appears.

napuböitnöi'dim

That she hither us comes looking

vö'co'rasa"ba all hours in

natarmám·rat pihờ natsoi'máma`c that we are her children where that we sad appear

\section{iti'koraksa'giD}

kuvi'pubö'itnöí'dida our filthiness among. Then she hither us will come= beholding,

avi'pugama'itwi'cturda

she from us will repulse

gactón'kam that heat

átiv nata'rma'mrat kuvia'mid·a'm.tö'ò $\mathrm{k} \cdot \mathrm{a}$ we that we are her children. Then not us over= will happen. 
kumia'mpihö'.ita'riwa'da gapa'r'nio'k·dam ${ }^{1}$ Then they not anywhere us small will make that= bad word on ${ }^{1}$

\begin{tabular}{|c|c|}
\hline $\begin{array}{l}\text { namaru' } \text { Nmam }^{2} \\
\text { that they are foreigners. } \\
\text { pi'miaso'sBidida } \\
\text { ye them will cast }\end{array}$ & $\begin{array}{r}\text { ga"'gurahö'van } \\
\text { Aside there } \\
\text { ha 'ctuicto'nkamökö't } \\
\text { any heat with. }\end{array}$ \\
\hline $\begin{array}{l}\text { bö'.itnớídida } \\
\text { Hither us will go beholding }\end{array}$ & $\begin{array}{l}\text { hö'ganavarid·a't } \\
\text { she who is our Lady, }\end{array}$ \\
\hline $\begin{array}{l}\text { avi'puta.'givida } \\
\text { she us will go covering }\end{array}$ & $\begin{array}{l}\text { böco'rasa'ban } \\
\text { all hours with. }\end{array}$ \\
\hline $\begin{array}{l}\text { kunkiha'p.í } \\
\text { With which thus is. }\end{array}$ & $\begin{array}{l}\text { má·t•ök } \\
\text { Know! }\end{array}$ \\
\hline $\begin{array}{l}\text { naparinsu'sBidat } \\
\text { that thou art my Guide, } \\
\text { Lord. }\end{array}$ & $\begin{array}{l}\text { inci'u'k in.o.'G } \\
\text { my Morning Star, }\end{array}$ \\
\hline $\begin{array}{l}\text { konkihap'í } \\
\text { With which thus is. }\end{array}$ & $\begin{array}{r}d i u^{\prime} \text { spö'cumbi'ak·a } \\
\text { God thee feel. }\end{array}$ \\
\hline
\end{tabular}

\section{TRANSLATION}

Hail! my Father, my Mother, my Morning Star. Forgive us these few words, ye who are our spirits who do watch over us through all hours. Ye watch over us when we arise at dawn and when we retire at dusk and in all hours. Ye need not look askance, our spirits. Ye will forgive us and ye will guard us, our spirits, here where we pass the night and the dawn. Do not look askance; we beseech you, put to flight the heat, aside where we walk not. Ye will cleanse us with the cold; far away will ye put to flight the heat. Ye will come to cleanse us. With your gray arrows will ye put it to flight, far away where we walk not. And with your chimales will ye shield us from the sickness. Aside will ye put it to flight, that no ill may befall us.

We beseech him who is our Guide, our Morning Star and our Father that he reach unto us his hand that we may be gathered into it so that he may shield us from the pestilence.

Likewise do we beseech our Lady of Guadalupe, she who was created within the white

1 "Unintelligible."

cloud in the seven beautiful heavens where sadly she doth appear. Hither she looketh in all hours, beholding her children, how pitiful we appear in our sinfulness. Hither will she look upon us who are her children and will cast from us the heat. Then will no ill befall us; then will the strangers who speak strange tongues not molest us. With the heat will ye cast them aside. And she who is our Mother will watch over us and will protect us in all hours.

So may it be! Know it and hear me, thou who art my Guide, my Morning Star and my Lord. So be it. May God bless thee.

\section{THE CALL OF THE FIESTA OF THE MILPA CUATA}

hu'giangiv ha'ha'cdus gamava'tiag Come! relations. Having bathed, gamamsu'sak cida'rsag kutsa'pmika.'ya those your sandals having put on. Then we say= hence will hear

$\begin{array}{lcr}\begin{array}{l}\text { hởga' } \\ \text { that }\end{array} & \mathbf{O}^{\cdot} \mathbf{B}^{\cdot} & \text { amöhödör } \\ \text { stranger } & \text { there from }\end{array}$

na·puamö’rin`ogim icamba'haG örhö'd·ör that he already goes running yellow broom within= from

na'puwa'nio'k·im hờg'a navarictu'tuk' that he already goes speaking that which is dark o'idak hu'rap höd`ör na’puva'hill midway from. That he already= mörimno'gim ic·a'pkö cimdu'na·G goes running well decorated himself having made ci'cwoD`ökö puvatu'tuatug gatud his plumes with already them carries his bow cibö G havaga.u"uD havagana'vsogad carries and that his arrows and that his wristguard.

ku'tsapmika'himöG

Then we say hence having gone hearing

a'möhödör there from

${ }^{2}$ Used in practically the same sense as $\mathbf{O}^{\cdot} \cdot \mathbf{B}^{\cdot}$ but generally collective. 
na'puva'nio' $\mathrm{k} \cdot \mathrm{im}$ that already goes speaking
mờrin'ogimöD having gone running.

kutsapamika'ög amina'bi Then we say hence having heard nearby. Oh! NOTE

The festival of the Milpa Cuata has a particular extra prayer or announcement which has no counterpart in the other fiestas. Several times during the night's ceremony, at the end of every song, the Master of the Fiesta, the man who has brought the sheaf of Milpa Cuata and supplied the other paraphernalia for the celebration, advances to the four quarters of the dance circle, east, north, west and south in turn, in company with a small boy dressed to represent the Morning Star. Both carry stalks of the forked twin corn and raise these on high, while the Master, in a loud, joyful voice, shouts out the prayer over the hillside.

\section{TRANSLATION}

Come, brethren! Come cleansed and with your sandals tied! Let us go to hear the stranger who cometh hither! He cometh running from out the yellow broom-grass. He cometh speaking from the slopes of the dark hills. Beautifully arrayed with his plumes he cometh. His bow he carrieth ready, his arrows and likewise his wrist-guard. Then, having given ear to him who cometh running and speaking from afar, let us go hence. Yea!

\section{I3. TO CONCLUDE THE FIESTA OF THE MILPA CUATA}

adio's in.o.'G inda'D inci'u'G To God, my Lord, my Lady, my Morning Star. api'ctunha'gicda hidi go $\mathrm{k}$ va'ik. Thou me wilt pardon this two three ni'.o'k• nanitbaivaumnö'i'pöctur $(\mathrm{da})^{1}$ word that I did hither already to thee (will) ${ }^{1}$ recite.

1 Probably incorrectly given in revision; future suffix is probably superfluous.
kuhi'dihö'madakamhö'kö’D apictunha'gicda Then this form with thou me wilt pardon navarumni"'o'k. go.'k va'ik. which is thy word two three na'nitumha'kiactur ku.inimö'd•ör.iD`a'giD`a that I did to thee tell. Then from here us will send da'dig gagö'gucdara nat(it)go 'kiptötu'gia ${ }^{2}$ health the succor that we (did) ${ }^{2}$ to both= sides may look.

ku'tiamha'ctuda.iD·am·acumdu' hi'di That did not anything us over already happen this tu'kipsa'gid i'nimö na'titiva.citu'k·ak' darkness within here that we did already= pass the night

navaricda'dikam

navarumnö'ik·ardam that is thy patio on

ha 'cumdu'kaphö'kö't some space of time with.

kupi'puitma·'kida hö'gagu'gucdara natgamiumha'k·icturd·a that succor that we to thee will tell

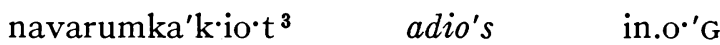
which is thy ceremonial rabbit. ${ }^{3}$ To God, my= Lord,

inda't inci'u'G kuhi'dihökö't my Lady my Morning Star. Then this with pictunha'gicda porki aviamha'thou me wilt pardon because not any= cicbai'gi'D nanma'sga'miamha'kiacturd·a how can that I more to thee may tell

höga na'varum.a'r'ag porki that which is thy form because

höga avaricda'ra'kam havaric 'idu'that it is value and it is= k·am höga'kö't a'via·micbai'giD treasure. That with not can. napgamaiumtö'vör.turda hö̀ga amöhö.vi'pu.That thou shalt lengthen that there thus= imá $\cdot c$ navarumhi'mda a'tiambiumappears which is thy way we not hither for thee=

2 Probably incorrectly given in revision; past prefix probably superfluous.

${ }^{3}$ At the altar are placed several figures made of cooked cornmeal dough in the form of rabbits. 
bö'p'a·uwda

may equal

api'citma'k'ia

thou us wilt give

go'kiptötu'gia ${ }^{2}$

to both sides may look.

\section{TRANSLATION}

Hail! thou who art my Father, my Mother, my Morning Star. Thou wilt forgive me these few words which I have spoken unto thee. With this formula, with these few words of thine which I have recited unto thee, thou wilt pardon me. Thou wilt send us health, thy succor, that we may behold about us. No harm hath come unto us in the darkness; here have we passed the night in health, a short time on this, thy court. Thou wilt give thy succor, which is thy rabbit, to us who have prayed unto thee. Hail! my Lord, my Lady, my Morning Star.

Thou wilt pardon me this for I cannot recite to thee more of thy formula, for it is rare and dear. It may not be. Thou lengthenest thy way which here appears and we may never complete it. Thou wilt give us succor, that we may behold all.

\section{I4. TO LEAVE THE OFFERINGS IN THE HILLS}

$\begin{array}{llr}\begin{array}{l}\text { adiu's } \\ \text { To God }\end{array} & \text { anihö' } & \text { napimputuda'da·r } \\ \text { ci'korhoabouts } & \text { that ye are seated } \\ \text { vicinity there } & \text { hasnaci'dúdu } \\ \text { as that hoards. }\end{array}$

kuticpuböhí'möt to'nimöra 'ciamnio' $k$ ·idim Then we hither were coming suddenly already to= you go speaking.

pero pi'miamha'c.uma'k'a pi'mica'p'tumBut ye not any will think. Ye in them yourselvess da'gia ganamaritgö'k'orak.ap'a kuha'will seize they that are our spirits in. Then=

1 Incomprehensible; informant was neither able to translate nor suggest revision.

${ }^{2}$ Probably incorrectly given in revision; past prefix probably superfluous. pu.pui'c.ò'p pimi'cata'nida ha.'gicdara thus also ye them will go begging pardon para napimiampihö'ci·tö'gia aticpuböhí'möt in order that ye not anywhere us will ignore. We= hither were coming

pubi'amnámö'kdam hi'di ha'vuhökö'D hither you paying this jicara with ha'va hi'di so'so's kupimitutand this bead. Then ye us= ha.'gicda napimpurkiö'kam hi'di will pardon that ye are dwellers this oi'da.a"ba natitpubö 'idáda hi'di hill at that we did hither arrive this amnöi'kardám na'titpui'n.igö'gu your patio on that we did here stay. kutö'maiamtán ha''gicdara pi'mThen continually you beg pardon. Ye= iambi'aka pihö' napimsoi'mö'rid’a not will feel anywhere that ye sad will feel na 'pimago'kiptönö'nöiD’a ha'pu.pui'c.ö·p· that ye to both sides will look. Thus also pi-mi'cata'nia ha"gicdara gana'maritye them will beg pardon they who are our= gö"k'orak ha'cnat.a'tiv.amtánim ha'gicdara manes as that we, we you go begging pardon hidita'kugumökö't porki avia'mthis fragment with because it not= ha'cicba'ík hacnatma's.ama''töD'a anyhow can as that we more you will cause to= know.

konki'hapí $\quad$ pim·a'tök inka'ök With which thus is. Ye know, me hear.

konkidio'spöcama'ri'dak $\mathrm{am}^{3}$

With which God you smallness. ${ }^{3}$

\section{NOTE}

After the conclusion of the fiestas, particularly after that of the rain, messengers are sent to the sacred places at the four cardinal directions around Azqueltán with jicaras decorated with beads and other ceremonial objects which they leave there as presents

\footnotetext{
${ }^{3}$ Difficult to translate.
} 
to the divinities of the localities, after reciting this prayer.

\section{TRANSLATION}

Hail! ye who are seated round about. Unbidden have we come here to speak unto you. But do not apprehend anything. Ye must be possessed of them who are our spirits. Also must ye beg their forgiveness, that ye may nowhere ignore us. We have come hither to pay you with this jicara and these beads, that ye may forgive us, ye who are the spirits of this hill, because we came here and stayed on this your court. Continually do we ask your forgiveness. Be not sad. Neither look askance. Ye must beg pardon of our spirits like as we now beg yours with this fragment, for we cannot tell you more.

So be it. Know it and hear me! May God be as a Father unto you.

\section{TO BEG PERMISSION TO ENTER A SACRED PLACE}

\begin{tabular}{|c|c|c|c|}
\hline $\begin{array}{l}\text { adiosum } \\
\text { To God. }\end{array}$ & \multicolumn{2}{|c|}{$\begin{array}{l}\text { aticböhi'möD } \\
\text { We hither came }\end{array}$} & $\begin{array}{l}\text { to"nimör.vacitu } \\
\text { suddenly already }\end{array}$ \\
\hline $\begin{array}{l}\text { ha·'nim } \\
\text { handling }\end{array}$ & $\begin{array}{l}\text { pero } \\
\text { but }\end{array}$ & $\begin{array}{l}\text { högakö't } \\
\text { that with }\end{array}$ & $\begin{array}{l}\text { anicböhimdaD } \\
\text { I hither was coming }\end{array}$ \\
\hline $\begin{array}{l}\text { amta'nim } \\
\text { you beggin }\end{array}$ & & $\begin{array}{l}\text { ha'gicdara } \\
\text { pardon. }\end{array}$ & $\begin{array}{l}\text { kuhöga'köD } \\
\text { Then that with }\end{array}$ \\
\hline $\begin{array}{l}\text { pimiambi } \\
\text { ye not will } \\
\text { look. }\end{array}$ & ka & $\begin{array}{r}\text { napimagc } \\
\text { that } y\end{array}$ & $\begin{array}{l}\text { kip tönö'nöiGda } \\
\text { to both sides will }\end{array}$ \\
\hline $\begin{array}{l}\text { kuga'gur } \\
\text { Then aside }\end{array}$ & $\begin{array}{l}\text { hö'v } \\
\text { ere }\end{array}$ & & $\begin{array}{l}\text { pimi.iu''rnid·a } \\
\text { ye will go lifting }\end{array}$ \\
\hline $\begin{array}{l}\text { högacto'n } \\
\text { that heat }\end{array}$ & & $\begin{array}{l}\text { hava } \\
\text { and }\end{array}$ & $\begin{array}{r}\text { gacko'k'dakam } \\
\text { that sickness }\end{array}$ \\
\hline dil & & Im.hö'kc̈ & $\begin{array}{l}\text { pimi.iD·a'gi } \\
\text { ye us will clea }\end{array}$ \\
\hline
\end{tabular}

ga'navaramu'umi ganavaramka'kvarak

They which are your ceremonial arrows which are your chimales

napimpuhö'kö't.itso'sbidim that ye with us go shielding ko'k·dakam sickness.

kuxa'pu.pwic.ö’p

pimiam-

Then thus also

ye not will=

bi'ak·a napimsoi'mö'rid·a kuticböhimöt feel obliged that ye sad yourselves will feel. Then= we hither came

amta'nim

you begging

lisensia

permission

para

nat.i'nituha'na
that we here may handle. Then ye not us will ignore.

kupimicma·'kam xö'p•ör kunö'n·id•a

Then ye give winds. Then will cause=

to fly

ga'gurahö'van kupimpuma'töN tunaside there. Then ye know. $\mathrm{Me}=$

ha'gicid adio's naparinsu'sbidad pardon. To God that thou art my Guide, inci'u'k

in. $0^{\circ} \mathrm{k}$ my Morning Star,

NOTE

my Father.

This prayer is spoken by anyone who enters a ceremonial patio or other sacred place for any purpose; particularly when coming to begin a religious performance or fiesta.

\section{TRANSLATION}

Hail! Unbidden have we come hither to arrange, but on that account I have come to crave your forgiveness. Do not therefore look askance. To one side will ye put away the heat and the pestilence and with all the cold will ye purify us. With your arrows and with your chimales will ye shield us from sickness. So ye need not feel sad. We have come hither to beg your leave to perform here. Do not refuse us. Ye will send your winds and will put to flight all ills. Know this and forgive mę.

Hail! thou who art my Guide, my Morning Star, my Lord.

\section{TO BEG PERMISSION TO LEAVE}

\section{A SACRED PLACE}

adiu's na'parino.' $\mathrm{k}$ naparinci'u'k To God that thou art my Father, that thou art= my Morning Star, 
naparinda.'t

that thou art my Mother. are seated

hasnacidúdu ni'cpu.amtánim ha•'gicdara as that hoards. I you come begging pardon

napimaringö'korak wöpuhímdam anihö' that ye are my manes before go on. Hereabouts na'pimpudádar ganavarica'p.ma'mcim that ye are seated that which is well appearing am.a"tockar.dám anihö' napimpumyour seat on. Hereabouts that ye yourselves= na'mö·k' ci'korxốvan navarci'vgo'k' o'hi encounter vicinity there that are seven beautiful tö'tvakdam pihö' napimpuskies on where that ye=

a'r'gidic ganavarictö'doG create. That which is green

am·ai'nikdám your petate on navarica 'pma'cimká.t that is well appearing outspread

navaricvi'g.ikam icxa'duk'am

that is.......... .......... na'.icva"utakat.ká·t

pixödör

where from that was drizzling, outspread

na'tpuböiwöpgö

natpubö'.inio' na'that did hither lighten that did hither speak. That= puamöhö'dör.apum.a'gim there from already goes conversing

na'pumöhö'that there=

dörmörin’ogim

from comes running

itci'u'k it.Q.'k iD'a.'t ati'cour Morning Star, our Father, our Mother. We= puta'n ha.'gicdara kuvi'tutbeg pardon. Then us will=

ha·'gicda hidita'kugumökö't porki pardon this fragment with because

a'tiv.iamha'cicba'ík natawöpau'da porki we not anyhow can that we them will equal because ti'carici'k·orak'am porki iti'kradökö't we are vile because our filthiness with ti'cputsoB·dím we ourselves go obstructing natawöpa $\mathrm{u} \cdot \mathrm{da}$ that we them will equal puya'm.hacicba·ik' not anyhow can ganavarahi ' 'mda that which is their way navarato't'norik

which are their suns.

kugö'kuti'puata'n ha''gicdara pardon phere $^{\text {pixö }}$

Then therefore we them beg that they are seated nampubö'itNö.ít wöcorasa'ba intám that they hither us behold all hours in. Here natpuda'Rim ticputö'maiasa'kcit pihö' that we go sitting we continually to them= weep where

natitpua"máccit

that we did already appear

navaranöí'kardá·m that is their patio on navarica'p.ma'citká·t navaricta' mai'that is well appearing, outspread that is white petate= $\begin{array}{llr}\begin{array}{l}\text { nikwotta } \\ \text { beneath }\end{array} & \text { pihö'dör } & \text { napuihi'k·mat } \\ \text { where from } & \text { that clouds up. }\end{array}$ ticputö'mai.am'a'turit ganavarci'vgo' $\mathrm{k}$ We continually them cause to know that which= is seven

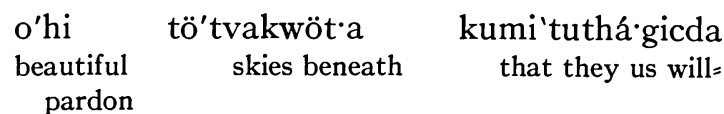
hidi takugumökö't bá·barip. this fragment with. North

hu'rnip' o'gipas hidi'kö't west south this with

iD`a'mahŏ̀wan nampubö.itnö.ít pihödör over us there that they hither us observe where= from

nampuböit·ö'kdim ganavarumnó $\mathrm{v}^{1}$ para that they hither us go extending that which is thy= hand ${ }^{1}$ in order

natpuha'bantud'ágimöt that we in it ourselves having enfolded may go= beholding

wöcorasa"ba kuha'ctuicto'nkam all hours in. Then any heat

naböma•'gida ga'gurahö'mi.u'r'nida that hither will come announcing aside hence will= go thrusting.

hö'ga navaraka'k'varhök·ö't That which are their chimales with mipuitso'B·ida navarau'umihök·ö't they us will go shielding which are their ceremonial= arrows with

1 Probably error for -anóv, THEIR HAND. 
mi'puga'gurahönơnid·a gacto'nkam wö·c they aside there will cause to fly that heat all icxö'pitkamököt cold with

mi.iD·a'giunida they us will go cleansing

ganamaritgö'korak

that which they are our manes

ci"a·rwöt·ahö napua'r.gidic

east beneath there that create

Morning Star.

konki'hapí ma'tök inka'ök

With which thus is. Know; me hear.

kudiospöcumbi'aka ${ }^{1}$

That God thee will sympathize. ${ }^{1}$

\section{NOTE}

This prayer is spoken after the termination of a fiesta, the following morning when the communicants are about to depart, or when one who has come alone to a sacred place for any purpose desires to leave.

\section{TRANSLATION}

Hail! my Father, my Morning Star, and my Mother who are seated round about. I come to beg your forgiveness, my spirits who have gone before. Round about are ye seated on your pleasant throne. Round about are ye met in the seven beautiful heavens where ye were created. On your green carpet, beautifully o'erspread with rain and drizzle, whence come the clouds, the lightnings and the voice, cometh running and counselling he who is our Guide, our Morning Star, our Father and our Mother.

We beg their pardon and they will forgive us this portion for we cannot equal them. For we are vile and with our filthiness do we obstruct ourselves; we may not equal their ways, their days. Therefore do we beg their pardon, where they are seated, watching us in all hours. Sitting here we do continually beseech them, having appeared in this

\footnotetext{
${ }^{1}$ Possibly -ambi'aka, you wILl sympathize; this final phrase is very frequent and difficult to interpret precisely. It probably carries some esoteric significance.
}

their sacred place, beautifully outspread, beneath their white carpet whence spring the clouds. Continually do we, beneath the seven beautiful heavens, tell them that they must forgive us this fragment.

From above us do they watch us from north, west and south whence they reach unto us their hand that we, wrapping ourselves in it, may go beholding through all hours. They will thrust aside whatever heat may draw near. With their chimales will they shield us, with their arrows will they put to flight the heat and with all manner of cold will they purify us, our spirits who have gone before to beneath the east where was created our Morning Star.

So be it; know it and hear me! May God bless you.

\section{TO DELIVER THE FIRE TO THE} CARE OF ITS GUARDIAN

esta' mui bien apiampum.a.'gaD It is very well, thou not wast thinking putudá·kat kuto"nimör.puba.ciumnio'k·it seated wast that suddenly hither already thee= speak.

kupica'ptumda'gia höga namaritgö'k·orak Then thou in them thyself wilt seize that that= they are our manes wöpuhímdam before go on. We thee beg

hactugökamö'köt anything greatness with. seize

it.o.'Ga'ba our Father in. apiamago'kiptönönöikda Thou not in two places wilt look. höganavarito 'G natpubö'i.ci'cvot amöhödör he that is our Father that did hither raise= plumes. There from

pixơdör natpubö'ixo't ganavaro'gaD where from that he did hither send he who is his= Father 
ci"arwötahö' napuo'idak navarita'm
east beneath there that he belongs who is our=
yellow
itci'u'G napubö.it'ök'dim ganavarno'vit
our Morning Star that he hither us comes ex-
tending that which is his hand natpuha'ban.tuD’ágimöt gamtönö·ídim that we in it ourselves having seized going beholding wöcorasa"ba kuti'pumtán há gicdara all hours in. Then we thee beg pardon. kupitutha'gicda hidi navarictuma'm Then thou us wilt pardon. This that is five o'hi tötvakwöt'a natpubö'iwöpgö beautiful skies beneath that did hither lighten natpubö'.inió' amöhödör natpuixi'k·mat that did hither speak. There from that did cloud up $\begin{array}{lrr}\text { navarci"a'rwöta } & \text { ba·'varip } & \text { xu''r'nip } \\ \text { which is east beneath } & \text { north } & \text { west }\end{array}$ o'gipa anihö ci'korhơ oímörimök south. Hereabouts vicinity there walking aka'himök namarmám'rat kutiputhem hearing that they are his children. Then did=

i'nihövadu'viá

here already arrive. making.

api'tutha 'gicda

Thou us wilt pardon

go'k vai'k ni'.o'khökö't porkiatiamha'two three word with because we not=

cicba·íG natma'sum'a'töD'a ganavarni'ok'it anyhow can that we more thee will cause to= know that which is his word

högansu'sbidat inci'u'k in.Q.' $G$ she my Guide, my Morning Star, Father, because

a'ni.ina'ba.ti'pua'p.úrr'

I me in did also remain

amnu'k'tur höga not guard that

kugö'k·u

Then therefore

hacna'numtö·da apicapma'mcimpucxo 'hi what that I thee shall say; thou well appearing= desirest ica 'picdáspam

well explained

haputu'ki·p

Thus darkness

pero ma'skise'a hidi takúgumököt but more than might be this fragment with

ani'cpuma.'tud

kupiama 'cum·a'k·a

I thee cause to know. Then thou not any wilt think;

pica.'aptumda'gia

thou in them thyself wilt seize manes.

ganamaritgökorak they who are our=

konkihapö'gia

With which thus only

nicum·a'tud

I thee cause to know.

kumsapicdiospöcumbi'ak·a kupsapan'u'k'Then they say God thee will sympathize. Then thou=

turda ganavarata'ík ganamaritgökorak say for them wilt guard that which is their= fire they that are our manes

anihö' namda'dárr navaricapma•'cim hereabouts that they are seated that is well= appearing

a'tockardám hidi navaramnöikardám ${ }^{1}$ seat on this which is your ${ }^{1}$ patio on.

konkidiuspöcumbi'ak·a

With which God thee sympathize.

\section{NOTE}

After the Cantador has prepared the fire for the fiesta and is ready to commence the ceremonies, he goes up to one of the men present, whom he has decided upon to be Guardian of the Fire (ci'ciktio' $t$ ), and addresses him as follows. Thereafter no one but him may touch the fire.

\section{TRANSLATION}

It is well that thou, seated there, didst not dream that of a sudden I would speak unto thee. Thou must be possessed by them who are our spirits who have gone before. Look not askance; we beg thy forgiveness. Neither be vain. Thou shalt be possessed of our Father. Thou must here watch for him

\footnotetext{
${ }^{1}$ Possibly should be -anöikar, THEIR PATIO.
} 
who is our Father who here hath raised his plumes.

From there beneath the east where he belongeth, whence he, his father, did hither send our Golden Morning Star, he now cometh, reaching unto us his hand that we, wrapping ourselves in it, may go beholding through all hours. Thus do we beg thy pardon and thou must forgive us. Beneath these five beautiful heavens did he send his lightnings and his voice. From afar come the clouds beneath the east, the north, the west and the south, where wander and hearken his children. Here they arrived but nothing befell.

Thou wilt forgive us these few words, for we cannot teach thee more the Word of my Guide, my Morning Star, and my Father. For it remaineth within me, because I have not obeyed his commandment. Therefore I know not what I shall say unto thee; thou desirest it beautiful and clearly explained, but thus it cannot be. For in darkness I also grope, but nevertheless do I teach thee this fragment. Be not offended; thou must be gathered unto them who are our spirits. Thus only do I give thee to know; may God bless thee. Thou must guard the fire of our spirits who are seated round about on their pleasant seat in this their court. May God bless thee.

\section{TO CURE THE SICK}

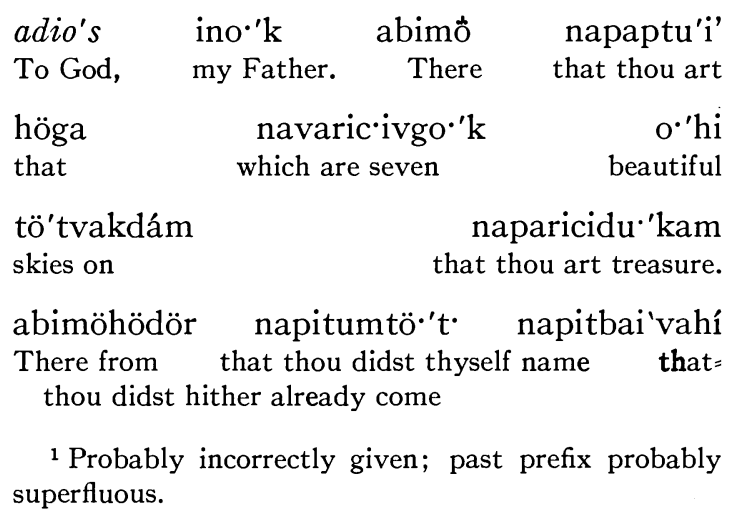

hidi navarum'ai'nigdam napitapdu' this that is thy petate on. That thou didst= already also do

$\begin{array}{lccr}\begin{array}{l}\text { tuvolunta'd } \\ \text { thy will }\end{array} & \begin{array}{c}\text { ku.i'na } \\ \text { then here }\end{array} & \begin{array}{c}\text { hidi } \\ \text { this }\end{array} & \begin{array}{r}\text { mai'ndam } \\ \text { petate on }\end{array}\end{array}$ kumu tö'tvaGdám kunapaitma`'k as skies on. Then that thou us givest umgö'gucdara vöc to'nora'ba thy succor all sun at. kup(it)bai'itma'kia ${ }^{1} \quad$ umci'v api'ctunThen thou (didst) ${ }^{1}$ hither us will give now. Thou= ha'gicda umta.'giv vacitu'D'a me wilt pardon thee before already will dance. ku.i'ni apictunha'gicda porke Then here thou me wilt pardon because nicarici"'krakam kupictunha.'gicda I am filthiness. Then thou me wilt pardon.

kupiamiD'a'k'ta'ka nati.i'akia' Then thou not us wilt permit that we shall fall. apiamvi'ak'a

Thou not wilt feel hactudö'kö anything with napasa'sa'rkadida api.iD·a'giD·a vöc that thou wilt go withdrawing. Thou us wilt send all icko' $\mathrm{k} \cdot$ dakam ${ }^{2}$

$a m e^{\prime} n$ sickness. ${ }^{2}$

Amen.

\section{NOTE}

Disease among the Tepecanos was commonly treated by a priest-doctor by ceremonial and magic means. The patient is laid on his back, the doctor standing at his feet. He blows tobacco smoke to the four winds and recites one of several prayers in a low voice. Five puffs of smoke are then blown on the invalid's hands, feet and forehead. The body is then stroked vigorously from the extremities to the center of pain and the latter is subjected to a vigorous suction. Thick spittle, blood, or a tangible object is extracted. The first is proof of affliction by a chan, a mythical water-serpent, the second of affliction by the spirits of the dead, the last of witchcraft. The object

${ }^{2}$ Undoubtedly error for $i c x o ̈ ' p i t k a m$, THE COLD. 
extracted is then rubbed and palmed until it disappears.

Smoke is then blown five times on the affected part and the cure is effected. The shaman rinses his mouth well and recites the prayer again to the west, whence the evil spirits flee. If the individual is very sick, a different prayer is repeated every third day.

The following prayer is of doubtful value. Together with no. 26 it was given to me to show the lack of antagonism between the old Tepecano and the Catholic religions, and was termed the "Our Father." The informant constantly compared the Christian prayer while giving it. It was originally claimed to be a prayer to beg permission to enter a sacred place.

\section{TRANSLATION}

Hail! my Father who art in the seven beautiful heavens. Thou art dear. From there where thou wast named, thou didst come to this thy carpet. Thou didst thy will here on this earth as in the heavens. Thou givest us thy succor daily. Thou wilt give it us now. Thou wilt pardon me; before thee will we dance. Thou wilt forgive me for I am vile. Thou wilt not allow us to fall. Thou needst on no account hold aloof. Thou wilt send us all the cold. Amen.

\section{TO CURE ONE VERY ILL}

adios in. $0^{\circ} \mathrm{G}$ inda't inci'u'k amumờdör To God, my Father, my Mother, my Morning= Star. There from

napivo'pmigda na.'varumu'umi ha'ba'nthat thou wilt raise which are thy ceremonial= arrows whence=

dör napgamihi'komagda na'pufrom that thou cloudest. That thou=

hơ’köt.inö'nid•a

with wilt cause to fly

ga"gura.hồvan apiD·a'giD·a aside to. navaricko' $k$ 'dakam which is sickness

gö'gu'cdara succor nagamupkitötu'gia that he again soon may see

ica'pum.ö·rdaD ku'.avi'amibiha"tuD'a.da'man.a 'cumdu'nia Then not hither anything above already will make. kupipuso'sbid·a Then thou wilt repulse icko'k·dakam sickness

na'varicda'di $k^{\prime} a v a \cdot r$ navarumbu'p'uivas which is health chimal which are thy faces= hö'köD cík•or navarumtöt‘vagiwöp'ta with vicinity which are thy skies beneath ci'a'rwöt'a ba'barip hu'rnip east beneath north west ogipas south.

kuhi'dihö'madakamhö'köt Then this creation with

api'ctunha'gicda hờga na'varum·ár thou me wilt pardon that who is thy child, dios in. $0^{\circ} \mathrm{G}$ inda't inciuk God, my Father, my Mother, my Morning= Star.

TRANSLATION

Hail! thou who art my Lord, my Lady, my Morning Star. From afar thou wilt raise thy arrows whence come the clouds. With them wilt thou put to flight the sickness. Thou wilt send us succor, that this invalid soon again may behold and feel himself well. No evil must come upon him. Thou wilt repel the sickness with the health of thy chimal, which is thy face, round about beneath thy heavens to east, north, west and south. With this formula thou wilt pardon me, who am thy son.

Hail! my Father, my Mother, my Morning Star.

\section{TO CURE ONE ON POINT OF DEATH}

adiu's naparinsu'sBidat inci'u'k To God, that thou art my Guide, my Morning= Star,

in. ${ }^{\prime \prime} \mathrm{G}$ navarci'vgok ohi my Father that are seven beautiful tötvakdám pihö na'pudá skies on where that thou art seated. 
napubö'itNöi'dim napuböit·ö'kdim
That thou hither us comest beholding that thou=
hither us comest extending

gana'varumnóv navarumtó ${ }^{\mathrm{N}}$ natputhat which is thy hand which is thy foot that we=

ha'bantud·a'gia para natga'mtunöíd·ida in it ourselves will envelop in order that we= will go beholding

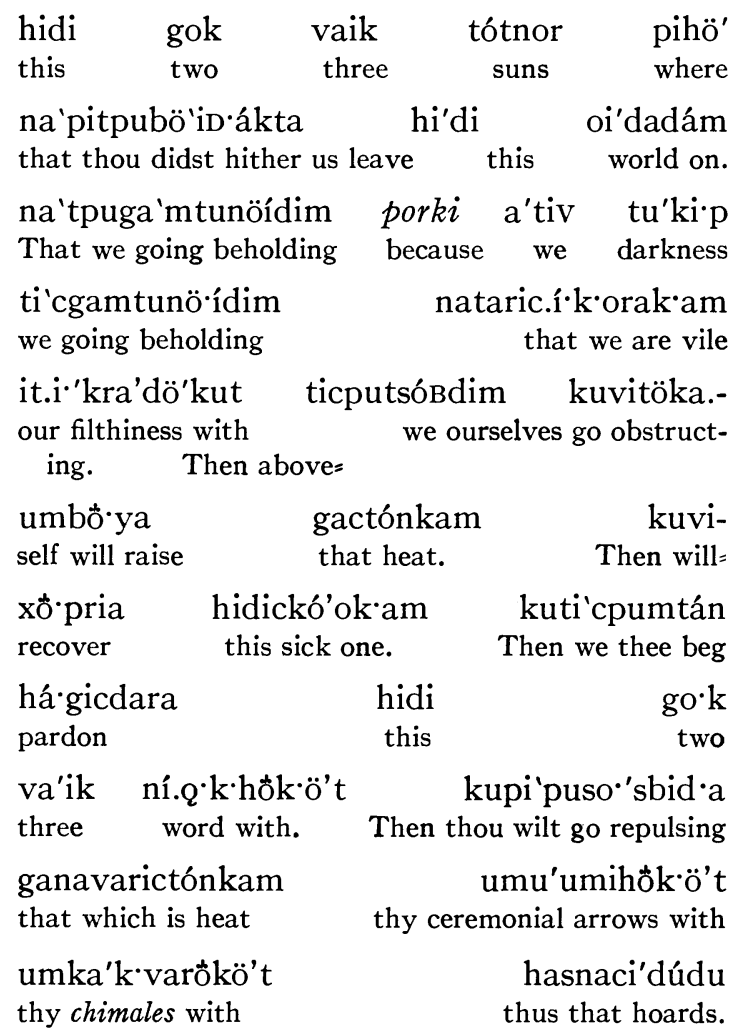

kupia'mago'kiptunơnöikda pi'cpubö'.it'ökda Then thou not to both sides wilt look thou hither= us wilt extend

höganavarumnóv

that which is thy hand

ába·n.tud’ágida

in us will go seizing.

a'cumwá·da kuwö•'c.ichö·pitkamök•ö't.pubö'itself will make.

Then all cold with hither=

iD’ágiuni'da naparindá·t kuvixöpria us will come cleansing

Then will recover hidickó.o'k·am kunkiha•'p.í nicumtá·n

this sick one. With which thus is. I thee beg

há·gicdara hi'di hö'mat gó $k^{*}$ pardon this one two

nío·k·hök·ö't cí'arwö't·ahö'

word with. East beneath there

nap'um.ár'git va·varip hú·r'nip that thou thyself formest north west o•'gipa hidi'köid’ám•öhö na'pudá south this with over us there that thou art= seated

navarci'vgok ohi tötvakdám that are seven beautiful skies on

napubö.itnöít wöco'rasa'ba kuhapu.puícơp' that thou hither us observest all hours in. Then= thus also

ti'cpumta'n há gicdara kuvi'we thee beg pardon. Then= pugamupkitötö̀gia högackó'ok·am höga again soon will behold that sick one. That navarumu'umihök•ö’D napidá·giuna which are thy ceremonial arrows with that thou= wilt cleanse;

kuga"gura.xö'pi.iú·rna gacko"k·dara then aside there wilt cast that sickness.

kua'viamimu' $\mathrm{k} \cdot \mathrm{ia}$

Then he not will die hidickó'ok·am kunkiha'p högia nic.um‘átut With which thus only thee cause to know na'parin.ó·k that thou art my Father, inci'u'k

my Morning Star. sympathize.

naparinsu'sBidat that thou art my Guide, konkidiospöcumbi'ak·a With which God thee will=

\section{NOTE}

This is the last resort of the shaman, recited when the patient is nearly on point of death. The accompanying treatment is the same as for the other prayers.

\section{TRANSLATION}

Hail! thou who art my Guide, my Morning Star and my Father who art seated in the seven beautiful heavens. Thence thou 
watchest us and reachest unto us thy hand and thy foot that we may be held in them and go beholding these few days in this world where thou didst leave us. In darkness we grope for we are vile and with our filthiness do we obstruct ourselves.

The heat must take itself hence that this invalid may recover. With these few words do we beg thy forgiveness. Thou wilt repel the heat with thy arrows and with thy chimales. Do not look askance. Thou must reach unto us thy hand that we may be gathered into it in all hours. Then will no evil befall us. With all manner of cold will our Lady purify us. Then will this invalid recover. So be it. With these few words do I beg thy forgiveness. Thou who wast created beneath the east, the north, the west and the south art seated above us in the seven beautiful heavens whence thou watchest us in all hours.

Thus do we beg thy pardon. Soon will this invalid see again. With thy arrows wilt thou cleanse him; thou wilt cast aside the affliction that he may not die. This only do I say unto thee, my Lord, my Guide, my Morning Star. May God bless thee.

\section{TO CURE ONE SICKENED BY THE SPIRITS OF THE DEAD}

\begin{tabular}{|c|c|c|}
\hline \multicolumn{3}{|l|}{$\begin{array}{l}\text { adio's } \\
\text { To God } \\
\text { tainest }\end{array}$} \\
\hline \multicolumn{2}{|c|}{$\begin{array}{l}\text { oi'dawö'p·ta } \\
\text { world beneath }\end{array}$} & $\begin{array}{l}\text { varumicto } \\
\text { that is thy } \&\end{array}$ \\
\hline \multicolumn{2}{|c|}{$\begin{array}{l}\text { ma·i'nik.wö't'a } \\
\text { petate beneath. }\end{array}$} & $\begin{array}{l}\text { ipurickoí'k } \\
\text { t ye are the }\end{array}$ \\
\hline $\begin{array}{l}\text { pihö‘wan } \\
\text { where }\end{array}$ & $\begin{array}{l}\text { ganavaricta' } \\
\text { that which is white }\end{array}$ & $\begin{array}{l}\operatorname{amk} u^{\prime} r a \\
\text { your corr }\end{array}$ \\
\hline $\begin{array}{l}\text { pihö } \\
\text { where }\end{array}$ & $\begin{array}{c}\text { napimpuoídaG } \\
\text { that ye pertain. }\end{array}$ & $\begin{array}{l}\text { kuni'cam } \\
\text { Then I you }\end{array}$ \\
\hline $\begin{array}{l}\text { gicdara } \\
\text { don. } \\
\text { e sick, }\end{array}$ & $\mathrm{k}$ & \\
\hline
\end{tabular}

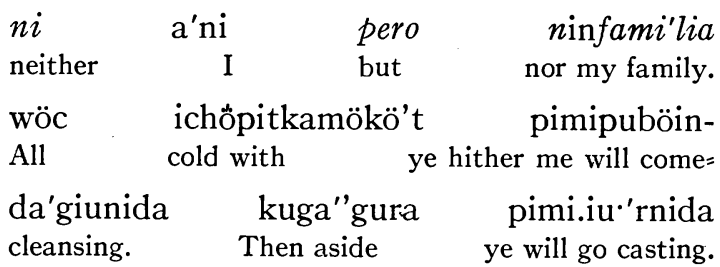

kuvia 'mindám.ha'ctu.indama 'cumwa'da

Then not over me anything over me itself will make.

kupimia 'mpihötunko'k·datuD·a ganavargö'

Then ye not anywhere me will cause to be sick. That= which is great

tö'tvakdám pihö' na'pu.ambi'á skies on where that he you holds

höga navarit. ${ }^{\prime}{ }^{\prime} \mathrm{k}$ ' ganavarid $\cdot \mathrm{a} \cdot \mathrm{t}$ he who is our Father she that is our Mother napubö'.it·ök'dim ganavarno'vit that he hither us comes extending that which is= his hand

natpuha'bantuD·a'gim kuwö'c.icxö'pitkam that we in it us seizing. Then all cold

avi'pubö '.iD’a'giuna na'varit.o॰'G para he hither us will cleanse that is our Father in= order

natpugamtönöí.dida hi'di oi'da.dám that we may go beholding this world on.

kuyamha'ctu.iD’ám.ha'cumwa'da

Then not anything over us any itself will make.

kupimimöm'.u'rin'ka höga navaramku'Then ye hither yourselves will cast that which= krus.avúi navaramö’kaD·a pixö' are your crosses with which is your shadow where napimpu.a'r'gidic navaramictö'do that ye are formed which is your green am·ainik.wö't·a pihö' napimpua'r'gidic your petate beneath where that ye are formed

höga navaramhi'komsa'git pihö' that which is your cloud between where nampu.ambiá ganamaritgő̉korak that they you possess they who are our manes wö'puhi'mdam nampubö'it·ö'k·dim before go on. That they hither us come extending navara.a"rak pixổ nampuhököDböiwhich is their form where that they with hither= 
a'r'gidic are formed ganavarci'vgo $\mathrm{k}$ they which are seven

tö'tvak.dám nampuda'dar skies on that they are seated

napurica'p'ma'cimká·t

that is well appearing, spread out

$\begin{array}{lcr}\text { kuha'pu.pïc.ö·p' } & \text { ti'cupata'n } & \text { ha·'gicdara } \\ \text { Then thus also } & \text { we also them beg } & \text { pardon }\end{array}$

ganamarickoí'k·am

they who are the dead seated

awo'poi.dám their paths on.

mi'm.u'rin'ka they selves will cast. nampuanihö'dá'dar that they hereabouts are $=$

kuga"gurahö̀wan Then aside there kuhi'diköD ami'tunThen this with they me=

ha'gicda konki'hap.í ni'c.am'a'tut kumi'will pardon. With which thus is I them= cause to know that=

tunha·'gicdán konkidios pöcambi'ak·a they me will pardon. With which God you will= sympathize.

\section{NOTE}

After death, at least before Christian times, a person became a puff of wind, wandering over the world and sickening those with whom it came into contact. When the priestdoctor's diagnosis showed sickness caused by the spirits of the dead, this being determined by the extraction of blood in the sucking examination, the following prayer was recited to cause the spirit to quit the body it was afflicting. The same prayer was also spoken to drive away a persistent haunting spirit.

\section{TRANSLATION}

Hail! thou who art Death. Thou belongest beneath the ground, beneath thy green carpet. And ye who are the Dead in your white fields where ye belong, I beg your forgiveness. Ye must not sicken me, neither myself nor my family. With all manner of cold will ye purify me; to one side will ye cast the sickness, that no ill may befall me. Ye must not afflict me.
From the great heavens where he who is our Father and our Mother holdeth you, he reacheth unto us his hand that we may be gathered into it. With all the cold will he, our Father, cleanse us, that we may go beholding in this world. Then will no evil befall us.

Ye must take yourselves hence to your crosses, your shadows, where ye were created, beneath your green carpet where ye belong. There within your cloud are ye held by our spirits who have gone before. From the seven beautiful heavens where they are seated in their pleasant broad court our spirits stretch unto us their forms in which they were created.

Likewise do we beg forgiveness of the Dead who are seated round about on their accustomed paths. They must take themselves hence. Thus will they forgive me; I warn them that they must forgive me.

May God have pity on you.

\section{TO SEIZE DEATH}

$\begin{array}{lcr}\text { adio's } & \text { naparin. } .^{\prime} \mathbf{k} & \text { insu'sBidad } \\ \text { To God } & \text { that thou art my Father, } & \text { my Pro- } \\ \text { tector, } & & \end{array}$ inci'u'k nda'D ani'cho'hi' my Morning Star, my Mother. I desire ku'piböin.tö'k·da gana'varumno'v para that thou hither me wilt extend that which is thy= hand in order

natuma'p·tuda'gia para na'.itwi'.um·a·'cda that we thee in will seize in order that she= with us herself will appear

gacmú $\cdot \mathbf{k} \cdot \mathbf{i k} \cdot a m$ para naD’ágia that Death in order that we shall seize anihö' wo'poidám ha'cnapumá r'giD hereabouts paths on as that she is= formed

ci'korhöwan

ha'snapu.oí.mör

ci"'arvicinity there as that she walks.

East $=$

wöt·ahö̉ beneath there amuhödör there from 


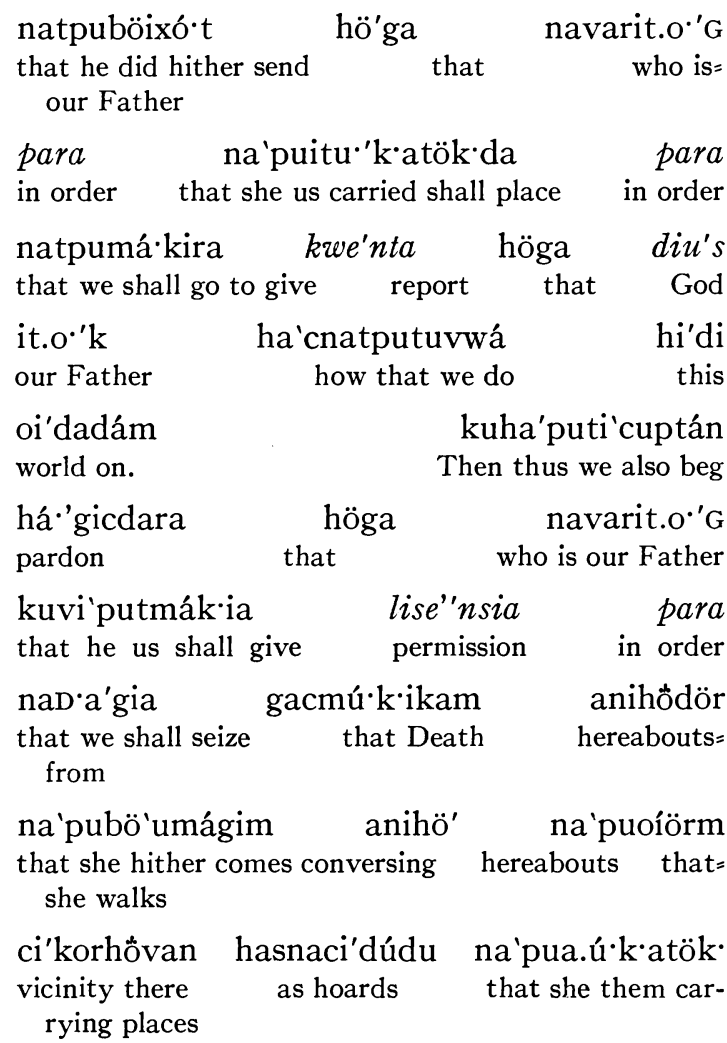

ganamarma'mrat kuti'cxó'xi kuvia'mkitthey that are his children. Then we desire that= she not=

pa'ro'nda porki tisör'kam na'tparó soon us shall maltreat because we many that she= did maltreat.

kuti'cputa'n há'gicdara gat.o' $\mathrm{k}$ Then we beg pardon that our Father

gaD·a·'D kuvi'pubö'it·ök·da ganavarnóvit that our Mother that he hither us will extend that= which is his hand

ganavartó'nat para natpwa'bantud·a'gia that which is his foot in order that we in it= ourselves shall seize

natia'mpihö'tuko'k'orda kuvi'putma'kia that we not anywhere ourselves will sicken. Then= he us will give

gani'ók·it para naya'mpihöit'u'k'k·atök·da that his word in order that she not anywhere= us carried shall place.

kuti'ho'tsa kuhímia pihö
Then we will dispatch her that will go where
$\begin{aligned} & \text { napu.a.'r'gidic } \\ & \text { that she is formed naputunúlk'aD } \\ & \text { that she guards }\end{aligned}$

gana 'varahu' $k \cdot u G$

ganamaritgö̀k'orak

that which are their torches they who are our manes

nampubö'itnöídim wöc orasába

that they hither us watch all hours in

na tica 'pitồr.daD.imá'c.dida a'nihö'

that we well ourselves shall feel will go appearing hereabouts

nat.o'ipu gana'varictö'dok ma•'inikdám that we walk that which is green petate on.

kuya'mpihö.'it·a·'ri.wa'da kuhapu.pï'ö’p'

Then not anywhere us small will make. Then thus= also

ti'ctá’n há gicdara ganavarci'vgok we beg pardon that which is seven

o'hi tö'tvakdám pihö' napudá beautiful skies on where that is seated gana'varit.ó $\cdot \mathrm{k}^{\cdot}$

he that is our Father,

gana'varid $\cdot a^{\cdot} \mathrm{D}$

ti'cpum·á'tud

We cause to know

maltreat

natarma'mrat konkidius pöcambi'ak'a that we are his children. With which God you will= sympathize.

\section{NOTE}

When there has been a great deal of sickness and many deaths among the Tepecanos, the five principal men of the village meet and hold a consultation. They decide that the Death Goddess has been too active and must be sent hence. They therefore undergo an ablutionary fast of five days. At midnight on the fifth day they meet in the graveyard and together recite in a low voice the following prayer, begging permission of the higher Gods to seize the Death Goddess and send her away. They all carry their bows and arrows. One remains in the town while the other four seek to the four winds. One of them encounters the Death Goddess in 
the form of a mortal woman and bids her begone and not molest them more.

The information volunteered to the effect that each person has a lighted candle in heaven, representing his spirit, and that the Death Goddess goes about snuffing them out, is probably of Christian origin.

\section{TRANSLATION}

Hail, O God, thou that art my Father and Mother, my Guide, and Morning Star! I beseech thee, stretch forth thy hand that it lay hold upon us. Then will the Goddess Death herself appear before us that we may seize her as she walketh about on her accustomed paths. She belongeth beneath the east whence our Father has sent her to carry us hence, so that we may give report to Him, our God and Father, of how we have acted in this world.

Likewise do we beseech of our Father that he give us leave to seize the Death Goddess, she who cometh whispering, stalking about and carrying off his children. We ask that she shall not harm us as already she has harmed so many.

Likewise do we beg of our Lord and Lady that he stretch forth his hand and his foot so that we may be upheld and not be sickened. He will give us his word that she shall not carry us away. We will send her where she belongeth where she guardeth the torches of our spirits who watch us through all hours. Then will we be well here where we wander on the green carpet. Then will we never be decreased.

Also do we beg forgiveness of our Lord and Lady seated in the seven beautiful heavens. We will let the Death Goddess know that nothing shall harm us who are the children of the Father.

May God bless you.

\section{TO PLACATE THE CHANES}

adiu's.um

su'di.örr

To God, na'pimpumtötök'

that ye are named seated

na'pimputunú·nkat

that ye guard

that

anihồ napimpuda'dar

hereabouts that ye are=

komaG ganamaritgö"koraG

cloud they who are our manes

anihö

Hereabouts

nampuda'dar

there

that they are seated

navarahi'which is their=

böpuhí $\cdot$ mdam

before go on.

ci'korxờvan

vicinity=

ha'cnaci'dúdu kuticbö'hí'möt amtánim as that hoards. Then we hither were coming you= begging

hágicdara konkiha'pí mátök• pardon. With which thus is. Know! pimiam.pixö.in·öid·uk·a

Ye not anywhere me will ignore

anihö̀

hereabouts

pusoi"máma'c

sad appear

dormag

parent seated.

kuni'cpuam·átud porki anta'sóna·t

Then I you cause to know because I did al= ready begin

$\begin{array}{lrr}\text { i'ntám } & \text { nano'ímö·R } & \text { na'npuamha'nciD } \\ \text { here } & \text { that I walk } & \text { that I for you }\end{array}$ meddle

gana'varicmám·dormaG amáinik konkiha'p.í that which is transparent your petate. With= which thus is.

anti'cpubi'amnámök·dam hi'di so•'sobö'köt I did hither you come paying this bead with

para napimia'mpihö'tunko'kdatud`a in order that ye not anywhere me will sicken niganmá.ma· $\mathrm{R} \quad \mathrm{i} \cdot$ 'ntám na'mpuo'ípu nor that my children here that they walk

amicmámdormaG

your transparent

amva'pamör.örr your lakes in.
${ }^{1}$ Said to be derived from tenchaniados, etymology unknown. 


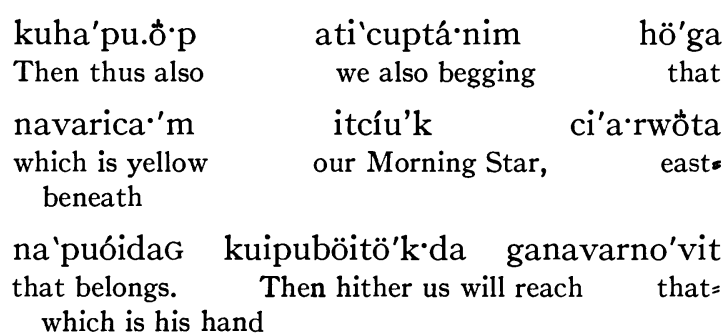

para

in order na'tpuhabantud’ágimöD that we in it us having seized

xu'viamha 'ctud’ám.a'cumwa'da

then not anything over us any itself will do

bö $\cdot c$

gacko'k·dakam pixơvvan ati'ctó.nimör.that sickness where suddenly=

putuhán gờk’ö ti’puta'n hágicdara meddle. Therefore we beg pardon

para naga•'gurhá.nöniD’a gactónkam

in order that he aside will cause to fly that heat

para na'miampihö'tutkókdatuda ganamar.in order that they not anywhere us will sicken they= who are=

su'di.ör.óik·am

water in chanes

nampuanihö.dádar•

that they hereabouts are seated

na'mpumtốtuk' that they are called

namputunú 'nkat that they guard

gi"g·ior

nampumtötök

rainbows that they are called.

ku.ha'p.í

Then thus is.

nicpuam·átut

I you cause to know

na 'pimaringö'korak' that ye are my manes.

adius.u'm naparinsu'sBidat

To God, that thou art my Protector, Star.

avi puböintồkdida

He hither me will come reaching hand.

ganavarno'vit that which is his=

kuyampihờ.indám.a'ctu.acumwa'da

konkiThen not anywhere over me anything itself will= do. With which=

ha'p.í nicputö'mai.umtán

thus is. I continually thee beg

há.gicdara pardon

na'parino 'G ko'nkiha'p.mátög dio's that thou art my Father. With which thus know. God pöcumbi'ak·a

thee will sympathize.
NOTE

The chanes are malevolent water-serpents which inhabit the springs and streams. They are horned and of many colors. They always travel in pairs, male and female, and love to stretch themselves through the clouds in rainy weather, head in one spring and tail in another, visiting. In this form they appear as rainbows. They are called the "winds of the water."

The chanes are vicious and will sting those who have not placated them. For this reason a native will never put his mouth to a spring while drinking; the water is dashed into the mouth with the hand. When thus bitten, malaria, fever, headache and many other ills result.

When a man decides to build a house and make his home on a new site it is necessary for him to placate the chanes of the spring whence he draws his water supply. To this end he prepares a jicara decorated with transparent small glass beads (water beads) and fills it with a gruel of pinole and water. This is scattered to the four winds at the spring while the following prayer is recited. The jicara is then left there as an offering.

\section{TRANSLATION}

Hail! ye who are called Chanes, who are seated hereabouts in the waters, guarding the cloud of the spirits of those who have gone before and are seated round about us. We come to beg forgiveness. Know ye that it is so. Ye must not ignore me nor my family who walk about here. Sadly do they appear beneath your crystal carpet where ye are seated. Thus do I give you to know, for already have I begun to walk about here and to meddle with your lucid carpet. So be it! I have come hither to offer you these beads that ye may not sicken me nor my children who wander here among your limpid lakes. 
Likewise do we beg forgiveness of our golden Morning Star who belongeth beneath the east. He will stretch unto us his hand so that, wrapping ourselves in it, no sickness may come upon us because we have meddled here unbidden. Therefore do we beseech that he will put to flight the heat. Then they will not sicken us, they who are called Chanes who are seated hereabouts in the waters guarding those that are called the rainbows.

Thus do I give you to know, my spirits. Hail! thou who art my Guide, my Morning Star. He will reach me his hand, that no ill may befall me. So be it! Know, O my Lord, that I do continually implore thee.

\section{TO CURE ONE SICKENED BY THE CHANES}

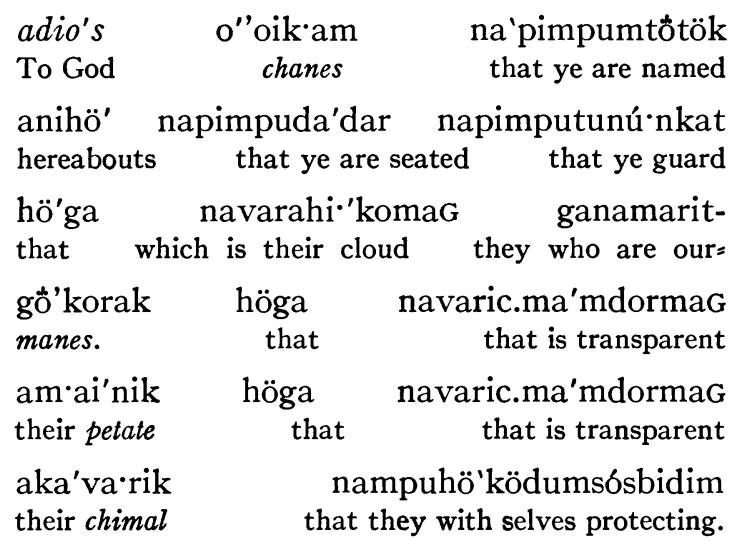

anihö'namdádar ${ }^{1}$ nampuanúkturid hờga Hereabouts that they ${ }^{1}$ are seated that they for them= guard that

navarahi'komaG which is their cloud na'maritgö'korak ha'pu.pui'cồp ti'camtánim há'gicdara Thus also we you beg pardon. kuga"gurahöpimitu.u'rinka ganavaricma'Then aside ye will cast that which is $=$

mdorma' amba'sa.ör namia'mpihö'.tuha'nda transparent your gourd within that they= not anywhere will meddle

${ }^{1}$ Although in the third person, evidently refers to the chanes. ganmá.mar they my children

ganamaramho'ho'cia ganamaramha'ha' those which are your jars griddles

namaramba'paidaka ganavaricma'mdormaG those which are your pitchers that which is transparent

amö'cig.ör namia'mpihötuamha'hi'cda your cornfield within that they not anywhere for= you will break

para napimiampihötuakok'datud'a in order that ye not anywhere them will sicken ganfami'lia gö'köni'puamá·tud porki that my family. Therefore I you cause to= know because

anihö'mioi'pu ganfami.'lia amicto'hereabouts they walk that my family they= nimờr'.bituha'nda gö'kö ni’puamtá'n suddenly hither will meddle. Therefore I you= beg

ha'gicdara porki niti'matơt pardon because I if cause to know hö'ga navarinsu'sBidat inci'u'k he who is my Protector, my Morning Star, kuhö'ga'vi'tuamko'k·daD'a kupi'mia'm'then he you will sicken.

Then ye not=

a'a·kda kuniti'amam·a'töt gö'kö later will say that I did not you cause to know. Therefore

ni'puamtánim há'gicdara wöc I you am begging pardon all orasa"ba koha'pu.pï'cơp ati'tá·nida hours in. Then thus also we will go begging ganavaritci'u'k kovibitö'kdida he who is our Morning Star, that hither us will come= reaching

ganavarno'vit para natha'ban.tuthat which is his hand in order that we in it=

D’a.'gimöt ga'mtönö'ídida ha'ctu us seizing will go beholding anything napuanihö'dörumágida ha'cnac·i'dúdu that from hereabouts will come thinking thus that= hoards. 
gö'kunipuama''giD

Therefore I you advise

ganavaricma'mdorma'

that which is transparent

konki'ap.í

pimima 'töhi

With which thus is. Ye must know.

diu's.pö'cambi'ak'a

God you will sympathize.

\section{NOTE}

When the priest-doctor has determined by the extraction of thick spittle from the patient in the sucking examination, that he is afflicted by a chan, he makes a chimal and a bastón with feathers of the heron and cleanses the invalid by waving the latter over him. He then deposits it at the spring whence the water is brought. The balance of the treatment is as before but the following prayer is recited.

\section{TRANSLATION}

Hail! ye who are called Chanes who are seated round about, guarding the cloud of our spirits. It is their transparent carpet, their limpid chimal with which they do shield themselves. Round about are ye seated, guarding the cloud of our Gods.

We beseech you, put away your saucers, your jars, your griddles and your pitchers. Hide them within your transparent gourd. Then will my children not meddle with them; then they will not break anything which lieth within your transparent cornfield. Then will you not afflict my family. Thus do I say unto you for already do my family walk about here and mayhap will meddle. This do I ask of you, for if I tell him who is my Protector and my Morning Star, he will then afflict you. Then do not say afterwards that I did not warn you.

Therefore do I implore you in all hours. And also will we beseech him who is our Morning Star that he stretch unto us his hand. Then, held in it, we may safely behold whatever may come unto us. Therefore do
I bid you begone into your transparent gourd. Thus shall ye know. May God have pity on you.

\section{TO RETIRE THE CHANES}

adio's.um

To God

pimi 'möm.u''rin'ká $\mathrm{am} \cdot \mathrm{a} \cdot$ 'iniGwö't'a your petate beneath.

ko'k·datud'a

will sicken

ni.a.'k•'da

I will tell Star,

in. $0^{\prime} \mathrm{k} \cdot$ my Father, na'pimaro"oik·am that ye are chanes. ganavaricma'mdorma' that which is transparent pimia'mpixö'.tuaYe not anywhere them= pimia'mása'nda porki högavi'tuamYe not later will weep because hou= ko'kdaD’a kuha'pí nicamta'nim will sicken. Then thus is; I you am begging ha·'gicdara pardon.

kupi 'mímöm.u'rinka ganavaricma'mdorma' that which is transparent

amba'kuri.öra pimti'pu.da'nyo

Ye if endanger

kuni 'tuamko'k·daD'a then I you will sicken höga that api'minwi'cdim ye me following, your water-gourd within.

navarci'vgo $\mathrm{k}$ which is seven a'rag napimpuö'köta'rgidic gö'ku formations that ye with are formed. Therefore nipu.amta'nim ha"gicdara konki'hap.í I you begging pardon. With which thus is.

pim·a'tök inka'ög pimihi'mia
Ye know, me hear. Ye will go pihö' napimpuaptu'i' ganavaramwhere that ye are that is your hi'komak.ör kudios.pöcam.öra'dakam cloud within. Then God you withinness. 


\section{NOTE}

This prayer is spoken after the invalid is convalescing from the sickness caused by the chanes and is intended to cause them to depart from the vicinity. It is recited to the west, whither they flee.

\section{TRANSLATION}

Farewell! Chanes. Ye shall take yourselves beneath your lucid carpet. Ye must not sicken my family, or I will tell him who is my Protector, my Morning Star and my Lord so that he may sicken you. Then do not afterwards weep if he shall have sickened you. So be it; I beg your forgiveness. You must take yourselves within your crystal water-gourd. For if ye follow to persecute me, I will sicken you with the seven forms in which ye were created. Therefore do I beg your forgiveness.

So be it. Know it and hear ye me! Ye shall take yourselves within your cloud where ye belong. May God bless you.

\section{TO BEWITCH}

\begin{tabular}{|c|c|c|c|}
\hline $\begin{array}{l}\text { adio's } \\
\text { To God, }\end{array}$ & \multicolumn{2}{|c|}{$\begin{array}{l}\text { in. } 0^{\circ}{ }^{\prime} \cdot \\
\text { my Father, }\end{array}$} & $\begin{array}{r}\text { inda.'D } \\
\text { my Mother, }\end{array}$ \\
\hline \multirow{2}{*}{\multicolumn{4}{|c|}{$\begin{array}{l}\text { inci'u'G abimö } \\
\text { my Morning Star. } \\
\text { sitter that }\end{array}$}} \\
\hline & & & \\
\hline $\begin{array}{l}\text { tö'tvak.dám } \\
\text { skies on. }\end{array}$ & $\begin{array}{l}\text { ku. } \\
\text { The }\end{array}$ & $\begin{array}{l}\text { nö' } \\
\text { ree }\end{array}$ & $\begin{array}{l}\text { navarum-ai'nak- } \\
\text { that is thy petate }\end{array}$ \\
\hline $\begin{array}{l}\text { dam } \\
\text { on }\end{array}$ & $\begin{array}{l}\text { napargöl } \\
\text { that thou a }\end{array}$ & tness & $\begin{array}{r}\text { naparicidu' }{ }^{\prime} 1 \\
\text { that } \mathrm{t}\end{array}$ \\
\hline
\end{tabular}

natarum'a'ma'r

ku.inimökmö̀dör

That we are thy children. Then here distant from abi.mö'dör hudur napituma'rgi afar from alone that thou didst thyself form napitbaivatuda'giu inimö napitivu'si that thou didst already hither cleanse. Here that= thou didst select

$\begin{array}{lrr}\text { huga } & \text { mari'a } & \text { na'purid'a·'D } \\ \text { that } & \text { Mary } & \text { that she is our Mother }\end{array}$

na't'una'kog

inimö

umwö't'amö that we are suffering here thee beneath. napitbaivatuda'giu ku.ani.mödör That thou didst hither already cleanse. Then= hereabouts from

napitbai'vavo'm hudö.r napit.that thou didst hither already arise alone that a'ban.ai'vavoi höga umkurosiG thou didst in it already recline that thy cross napitmu' amumö napitpuagö'i that thou didst die. There that thou didst= already fall

navaricda'dik·am

which is health

navarictutö'G·am.ör

which is darkness in to'tnorig kuabimöapti'ma'cir asa'giD suns. Then afar thou didst appear them=

navarumva'sa'ör which is thy box within between

höga namaricko'i'kam ku.inimö̀ör that which they are Dead. Then here from napithapuva't'utơ höga navartö'tvakdám that thou didst thus already behold that that= is skies on.

naparda'kam napara'ö'k·amhökö'D dios

That thou art sitter that thou art arrangement= with God

naparin. $0^{\prime} \mathrm{k}$ naparumnö'icturiD'am

that thou art my Father that thou art thy observation on.

ku.ami.dör napubaivatuda''giuna Then there from that thou hither already us wilt= cleanse

$\begin{array}{llr}\text { natöpkivoi'nök } & \text { hidi } & \text { maindam } \\ \text { that we also soon journey } & \text { this } & \text { petate on }\end{array}$ napöpkitma.'kim gögucdara kupibaithat thou also soon us giving succor. Then= thou hither=

iD’ágiuna höga navaricda•'dikam us wilt cleanse that that is health navarumökaDwö'ta' naB'aiiD·a·'giD·a that is thy shadow beneath that thou hither us= wilt send

natapövabö'iya höga navarichö'pitkam that we already will carry that which is cold 
navarumno'nov.ám kudiköt pictutha•'gicda which are thy hands in. Then this with thou us= wilt pardon

porke

because

nataric.i"korak·ám

ku.hidi.hömadakamhö'kö't

Then this formation with

navargö'gucdara

amen

which is thy succor. Amen.

\section{NOTE}

This prayer is merely one of several modes of casting spells of witchery, the others not entailing the use of any set prayer and savoring more of European custom. Even this, however, is of dubious authenticity as its resemblance to Christian philosophy is only too evident. In fact it was given in order to prove to me the lack of antagonism between the old Tepecano religion and Catholicism and was entitled the "Creed." I have great suspicion that it was created to suit the occasion, like no. I8. It was originally said to be a prayer to beg permission to enter a sacred spot but my principal informant pronounced it to be a prayer to bewitch.

It is recited at midnight when the one whom it is desired to bewitch is asleep, and is addressed to the pagan idols (cidudkam) and the Christian cross. A fast is likewise enjoined. Then the supplicant goes to the cemetery and lights a wax candle and buries there a figure he has made in representation of the hated one. It is buried at the foot of the cross and a prayer said entreating the death of the individual.

\section{TRANSLATION}

Hail! thou who art my Father, my Mother, and my Morning Star who art seated afar in the heavens. Here on thy earth thou art powerful, art dear. We are thy children. From afar where alone thou wast formed thou didst come to cleanse us. Here thou didst choose Mary, the Mother of us who suffer here beneath thee. Thou didst purify

us. From hence thou didst arise alone, thou didst lay thyself on thy cross and die. There thou didst descend into thy grave, into the darkness for three days. Afar thou didst appear among the dead.

From here thou didst behold Him who is in heaven. Thou art seated with the chosen, God, who art my Father, which is thy thought. From there thou wilt send purification to us who also journey through this world, and give us succor. Thou wilt come to cleanse us with the health which is beneath thy shadow; thou wilt send us the cold which is in thy hand that we may lay hold upon it. With this thou wilt pardon us, for we are vile. With this formula thou wilt send us thy succor. Amen.

\section{TO CURE FROM WITCHCRAFT}

adio's inda't inci'u'k To God, my Mother, my Morning Star. anipumta'nim hágicdara kovi'I thee am begging pardon that=

tö'k'owumböya above itself will take

avi'puböintök'da

He hither me will stretch my Morning Star

ci"arwö'tahö

east beneath there will recover

hidickó'ok·am this sick one.

komi'pu.hívo·i's that they bewitch.

icxö॰'pitkamơkö't

Cold with

thou
thou

a 'pi.ida''giunida

hö'ga namarumú.umihökö't ha'vanava'rictá that they are thy ceremonial arrows with, and which= is white

amka'varikökö't1 ku.ga'gura.há'pi'mi.your ${ }^{1}$ chimal with. Then aside to, ye=

1 The change from second person singular to plural is rather inexplicable here. 
iu''rnida

will go repulsing

Then I you beg

Mother,

in.ó $\mathrm{k} \cdot$

kua 'nibi'aka

my Father.

Then I will have kuni 'puamtán

ganavarickók·dakam that which is sickness.

há'gicdara naparindá·t pardon that thou art my=

kinihö'ganahívo•is

than even he who is bewitching. Then ye not will give

$l i \cdot s e^{\prime \prime n}$ sia

permission

ku'pixờ.puita."riwa'da that anywhere us small shall make

hidicto'nkamököt

this heat with.

höganavarinciú'G

He who is our Morning Star

avi'pubö.in.da'giunihida kuvia'mina'p.hak'he hither me will come cleansing that not in me back=

gö'cia gactónkam hidi

will fall that heat. This

na 'varinú'umi.hökö

which are my ceremonial arrows with I me will go protecting.

kuvia'mindám.ha'ctuacumdúnia konkiháp.í Then not over me anything itself will make. With= which thus is.

pima'tök piminka'ök kudio's.pöcamYe know. Ye me hear. Then God ye=

ö'ra'dak·am

withinness.

\section{NOTE}

When a man is ill and suspects witchcraft he sends for a doctor of reputation. The latter bathes and fasts seven days. It is revealed to him in his dreams and later verified by examination of the patient whether he is sickened by will of God, by a chan, by disembodied spirits, or by witchcraft. Kneading and squeezing the joints is one of the criteria, sucking being another, the drawing of blood being a certain sign of witchcraft.

Having assured himself of the cause, the doctor brings his ceremonial arrows and other paraphernalia. First three arrows are placed around the patient's head and another at his feet, stuck in the ground. The one to the left of the head is then raised and carried to the foot and these two are lifted, one in either hand, and pointed in turn to the east, north, west, south and zenith, the prayer being repeated five times, once to each direction. Then the five ceremonial circuits are performed around the sick man and he is sucked vigorously. The arrows are then replaced, two at the head and two at the feet. The doctor stands at the foot, then goes to the right and performs the sucking operation again. He then goes to the patient's head and spits in his hand to note the result of the sucking treatment. This is repeated five times on different parts of the body, each time returning to the sick man's head by a counter-clockwise direction. Usually some tangible object is extracted by these means. To finish the treatment the doctor seizes all four arrows, two in either hand, and circles them over the patient to purify him. The treatment is repeated every three days for five times and is said to be generally efficacious.

\section{TRANSLATION}

Hail! my Mother, my Morning Star. I beseech thee that this heat may take itself hence. My Morning Star must stretch unto me his hand from beneath the east where he belongeth. Then shall this invalid recover. Mayhap something is lacking that thus they bewitch him. But it must not be so. Thou wilt cleanse him with the cold and with thy arrows; with your white chimal will ye cast aside the pestilence. Therefore do I implore you, my Lord and my Lady. I must have more power than even he who is bewitching. Ye will not allow him to molest us with this heat. Our Morning Star will come to cleanse me that this heat may not return unto me. With my arrows will I shield myself, that no ill may befall me. So be it! Know ye it and hear me!

May God bless you. 


\section{TO SOW THE CORN}

adio's naparin.o'G naparinsu'sbidad

To God, that thou art my Father, that thou= art my Protector,

inci'u'G tunhá·giciD a'nitsapita'.putö.ö'í my Morning Star. Me pardon I did say= almost sowed.

ku'ni.i'ni.puciwa''k

ganavarum·ar

Then I here scatter

napitpubö'iho't

that thou didst hither send that she did here appear

hi'di navarictödo
this

um·ai'nikdám thy petate on.

hi'kom na.oímör

Cloud that wanders

o'hi tö'tvak.wö'pta

beautiful skies beneath

na'pu.ivu'snia

that she will arise

$\begin{array}{ll}\text { uv } & \text { napumtö'tök } \\ \text { female } & \text { that she is called }\end{array}$

navarici'vgok

which are seven

pina 'pui 'cikö'kwá where that she will rest höga that

$\mathrm{a}^{\prime} \mathrm{ra} \cdot \mathrm{k}$ creature

na'varuma' $R$ that is thy child.

kuha'pu.pïcöp ti'cumta'n hàgicdara

Then thus also we thee beg pardon

naparin. $0^{\circ} \mathrm{k}$ naparinda.'t

naparinthat thou art my Father, that thou art my=

Mother, that thou art my=

su'sbidat inci'u'k napu.uma'r'giD

Protector, my Morning Star that is formed

ci'a·rwö't'ahöwan

napitpuböi.ho't east beneath there that thou didst hither send

ga'm‘ár kuti'pubö'idu'via is'o'soigim that thy child. Then did hither arrive weeping

hi'di oi'dadám para

this world on in order

na'puitgö'guciD’a para natpukáda that she us will succor in order that we shall eat natga'mtönöidida hidi óidadám that we will go beholding this world on i'ntám natpumö·rin•ok hiditukip.sa•'git here that we run this darkness within i’ntám natpuvói.nug hi'di oi'dadám here that we journey this world on. kotipum·a·'tud kuti'pu.i'ni.citö.ö'cia Then we thee cause to know that we here will sow na'kutnú'kda hö'ga na'varum’áR to see if we will guard she who is thy child.

kupia'mago'kiptönönikda pi'cpuböin'tö'k'da Then thou not to two sides wilt look, thou hither= me wilt stretch

ganavarumnóv pa'ra nanha'bantundágimöD that which is thy hand in order that $I$ in= it myself may seize

gamtönö̀idida wö‘c o'rasa"ba

konkihap.í ni'cpum'a'tut naparin-

With which thus is. I thee cause to know that= thou art my=

su'spidat inci'u'k ino'G kunki'hap.í Protector, my Morning Star, my= Father. With which thus is.

dios.pöcambi'ak'a

God bless you.

\section{NOTE}

After the first heavy rain in June the corn is planted. A fast of five days and a purifying bath are the primary requisites. After this has been undergone small beads and a jicara of pinole mixed with water are prepared. The beads are placed in the four corners and in the center of the field to prevent injury by crows and other animals. The pinole water is then sprinkled to the four cardinal points and the prayer is recited while facing east. The pinole serves to prepare the soil for the reception of the kernels. The corn may then be planted but the kernels taken from the twin ears, the Milpa Cuata, must be planted first.

\section{TRANSLATION}

Hail! thou who art my Lord, my Guide and my Morning Star. Forgive me because I am about to sow. Here am I scattering thy daughter whom thou didst send hither to appear on this thy green carpet. The cloud wanders beneath the seven beautiful heavens where she will come to rest, where 
will spring up the maiden who is thy child. Likewise do we beg forgiveness of thee, my Father and Mother, my Guide and Morning Star, who dwellest beneath the east whence thou didst send thy child hither. Here did she arrive in this world weeping, to succor us that we might have food and might go beholding where now we grope in darkness, journeying through the world. We say unto thee that we will sow here, if perchance we may guard well thy daughter. Do not look askance; thou must reach me thy hand that I may be held in it and go beholding through all hours. Thus do I say unto thee who art my Lord, my Guide and Morning Star. So be it.

May God bless you.

\section{TO REAP THE MILPA CUATA}

\begin{tabular}{|c|c|c|}
\hline $\begin{array}{l}\text { adiu's } \\
\text { To God, }\end{array}$ & $\begin{array}{l}\text { a'raG } \\
\text { creature }\end{array}$ & $\begin{array}{l}\text { uv } \\
\text { female }\end{array}$ \\
\hline
\end{tabular}

$\begin{array}{lll}\text { a'nihö } & \text { napuo'idak hacnaci'dúdu } \\ \text { Hereabouts } & \text { that thou belongest thus that }\end{array}$
hoards

ci'korhö'wan

vicinity there.

navarci'arwö't:a

That is east beneath

amöhödör natpubö'imho't ganavarum.o $\mathrm{k} \cdot$ there from that did hither thee send he that= is thy Father

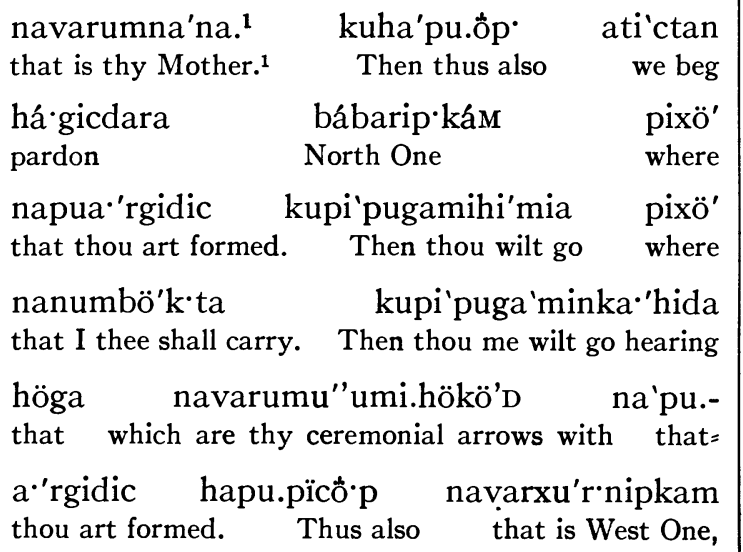

1 nana, MAMA, childish word for mother. hu'huktio't na'pumtö'tök kuha'pu.Pine-Man that is called. Then thus= pï'cồ $\mathrm{p}$ • ti'ctan há gicdara also we beg pardon ganavaro'gaD navardö"uD kutia'mihe that is her Father that is her Mother. Then= pixö'páro’n’da kuti'nöíd’a pönö'gitnóv we not anywhere will maltreat. Then we will watch= her like our hand.

kuha'pu.pïcô‘p' ati'ctan há'gicdara Then thus also we beg pardon höganavaricta' to 'vörip cidu'kam that which is white star fetish napumtötök amögipa amo that is called south there natpumácir ganavarma'rat kuthat did appear she that is his child. Then= ti'cputá'n há'gicdara ganavaro'gat we beg pardon he who is her Father havaganavardö'.uD kuti'pugama'hí anihö' and she who is her Mother. Then did already go hereabouts

ci'korhö'wan avi'puvạ'niók·im kuvicinity there she already speaking. Then= ha'pu.puicờp t ti'pumö'vadu'via anihö' thus also did hence already arrive hereabouts o'imörimök ci'korhö'van sá·kimöG having walked vicinity there having wept pumö'vadu'via navaro'gatvwí puva'hence already arrive who is her Father with already= 'a'G kumi'pupa'ro'n ganamarmámraD tell that they maltreat they who= are his children.

kugöku aticpugömhờwan ${ }^{2}$ kuti'puinór· Then therefore she did away. ${ }^{2}$ Then did return navaro'gat.wí a'bimöhớwan pixö' that is her Father with afar there where na'tpuku'gad navarci'vgok $6 \cdot$ hi that she did finish that are seven beautiful tö'tvakdám pixö' napuda' ga.o.'gat skies on where that is seated he= her Father.

${ }^{2}$ Verbal in form but with locative in place of verbal stem. 
koha'pu.pwi'cö·p· ati'cta'n há'gicdara Then thus also we beg pardon; ti'pum·a·k ganavaritni'o'k kutiamipihö'we thee give that which is our word that we= not anywhere will=

páro'nda kuica'pti'mötö'kia konkipia'mmaltreat that well we hence will place. With= which thou not=

bi'aka napihö'soi'mö'rid'a pia'm.wilt need that thou anywhere sad wilt= feel. Thou not=

ago'kiptönö'nikda sa"rak napumtötök to two places wilt look MilpaCuata that= thou art called

napara'rak.úv amöhö'dör na'punio'kim that thou art creature female. There from that= thou speaking

umhi'kom.örhödör hi'di navarictö'do thy cloud within this that is green

mai'ndam na'pitpum·ácir kupictunhá'gicda petate on that thou didst appear. Then= thou me wilt pardon

pihö' nantó'nimör.i'civo'mikda kupia'manywhere that I unbidden will raise. Then thou= bi'aka napihö'soi'mö'ri'da kugöku not wilt need that thou anywhere sad wilt=

feel. Then therefore

ni'pumtán há'gicdara

I thee beg pardon.

pöcambi'aka

you will sympathize.

\section{NOTE}

When the corn is ripe and the harvest time has come, the owner of the field goes forth and reaps all the ordinary ears of corn. But the Milpas Cuatas, the corn plants with a forked stem and two ears, are left standing after the others have been gathered. Then the field is encircled with ceremonial circuits as many times as there are Cuatas within and the following prayer is recited.

\section{TRANSLATION}

Hail! thou who art called Maiden. Round about us art thou met! From beneath the east did thy Father and Mother send thee hither. Likewise do we beseech him of the North where thou belongest. Thou must accompany me wherever I may carry thee. Thou must harken unto me, formed as thou art with thy arrows. And also he of the West who is called the Pine-Man. We promise her Father and her Mother that we will not maltreat her; we will guard her like our own hand. Likewise do we beseech him who is called the White Star Cidukam who belongeth in the south where appeareth the child of the Father. We beseech her Father and her Mother.

Hereabouts did she walk, bemoaning. Then, having wandered and wept here she returned unto her Father and told him that his children had mistreated her. Therefore did she depart; she returned unto her Father and arrived there afar where he is seated in the seven beautiful heavens. ${ }^{1}$

Thus do we pray. We give thee our word that we will not mistreat her, that we will guard her well. Thou needst not feel offended. Nor look askance, Milpa Cuata, as thou art called, maiden. Speaking from within thy distant cloud thou didst appear on this green carpet. Thou wilt forgive me if, unbidden, I reap. Do not feel sad; on this account I beg thy pardon.

May God bless you.

\section{TO BEG PERMISSION TO HUNT DEER}

anicbö'himdaD to"nimör puamta'nim I hither coming was unbidden you begging hö'gam namaramso'soik· anihö'van they that they are your pets. Hereabouts nampu.oi'pö höga namarictu'tu'k' that they walk that that they are black ói'dak'.a"'ba su'suimar nampumtö'tök. hills in deer that they are called höga navarictö'dog amai'nikdám that that is green your petate on.

${ }^{1} C f$. JAFL, xxvir, I 55 . 
anihö̉

nampua $\cdot$ 'rgidic

Hereabouts hacnaci'dúd·u thus that hoards. kuha'pu.pwicồ'p

Then thus also

xö'mai.intane·'tip’a

one me will lend

xi'komörhővan

cloud within

xa'pu.pwi'cö·p

thus also

a'nicho'hi

I desire

napimthat ye=

navarci'vgo'k' o.'xi that is seven beautiful

nampuóip'u $\mathrm{ku}$ -
that they walk.
ani'camtán ha•'gicdara I you beg pardon.

kupi'mipuma'töhi

Then ye know

ganavarxö'pör

they which are winds. gami'nka'hida

me will go hearing

na'mpuanihö'.mö'rin'ok'

That they hereabouts run

that which is green

na'mpuanihö.soi'ma'ma'c that they hereabouts sad appear

höga navarakai'k'orag navarinsu'sBidat That which is their master who is my= Protector,

inci'u'k in. $0^{\prime} \mathrm{k}$ '

my Morning Star, my Father. Then I cause= to know

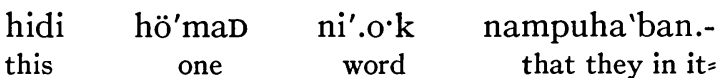
a.rgidic namaramso'soi'k·am nampumare formed that they are your pets that they= tö'tök konkiha'p.ma'töD inka'uk tunare called. With which thus know; me hear, me= ha'gicit pardon.

\section{NOTE}

The deer is the animal of consummate importance in all the religions of the Tepecano region $^{1}$ and around it center many ceremonies and rites.

When a man desires to hunt deer, which is a requisite for certain ceremonies, he commences a fast of seven days. On the first

${ }^{1}$ Cf. Lumholtz, Symbolism, p. 22.

2 Nahua otlatl, the base of a reed with branching roots which are trimmed and decorated to represent the head of a deer. $C f$. Lumholtz, Symbolism, p. $5 \mathrm{I}$. day he goes to the Cerro del Cántaro with an otate ${ }^{2}$ decorated with beads, to resemble the head of a deer, a jicara decorated with beads, and a chimal of pure white cotton. The otates have the same name and spirit as a deer and are made with green beads for the eyes. But if no otate is available a figure of a deer may be made of clay or wax and used instead. At the Cerro del Cántaro the supplicant leaves his offerings and recites the prayer.

The following day he hunts to the east, the third day to the north, the fourth to the west and the fifth to the south. Thereafter he may hunt where he wishes as long as he desires. But the first deer secured must be entirely distributed among the others; he may not touch it. Candles must be made of the fat and he must light one and put it in his house before setting forth again. This is for the spirits. ${ }^{3}$

For the Fiesta of the Milpa Cuata the deer of which the chuales ${ }^{4}$ are made must be caught in a snare and cooked whole, head and all.

\section{TRANSLATION}

Unbidden have I come hither, craving your pets which wander about in the dark hills, the deer as they are called hereabouts on your green carpet where they belong. I ask that ye lend me one of these which wander in the seven beautiful clouds. Likewise do I beg your forgiveness. Ye should know that they may hear me in the winds, running about on their green carpet where mournfully they appear. Their Master is my Lord, my Guide, my Morning Star. I will speak unto him the one word with which were created these which are called your pets. Know it; hear me and pardon me.

${ }^{3}$ Uncertain whether the spirits of the deer or whether disembodied or unembodied anthropomorphic spirits.

${ }^{4}$ Nahua chualli, a mush made of pinole and finely chopped meat, cooked in corn husk; practically equivalent to tamale. 


\section{I. TO RID THE RANCH OF SCORPIONS}

adio's naparinci'u'k· apipubö.in·öidida To God, that thou art my Morning Star. Thou= hither me wilt come watching,

kuya'm.inda'mactuacumwa'da $d i \quad$ anihö that not over me anything itself will make of hereabouts

\begin{tabular}{|c|c|c|c|}
\hline \multicolumn{2}{|c|}{$\begin{array}{l}\text { namputukík } \cdot \text { iö } \\
\text { that they live }\end{array}$} & $\begin{array}{l}\text { hi'di } \\
\text { this }\end{array}$ & $\begin{array}{r}\text { oi'da.dám } \\
\text { world on }\end{array}$ \\
\hline \multicolumn{2}{|c|}{$\begin{array}{l}\text { namictökö.u·t } \\
\text { that they vicious }\end{array}$} & $\begin{array}{l}\text { anihö' } \\
\text { hereabouts }\end{array}$ & $\begin{array}{l}\text { namput } \\
\text { that the }\end{array}$ \\
\hline \multicolumn{3}{|c|}{$\begin{array}{l}\text { namarna'na·skör } \\
\text { that they are scorpions. }\end{array}$} & $\begin{array}{l}\text { ha'pu.p } \\
\text { Then tl }\end{array}$ \\
\hline \multicolumn{2}{|l|}{$\begin{array}{l}\text { ni'cata'n } \\
\text { I them beg } \\
\text { will take }\end{array}$} & $\begin{array}{l}\text { dara } \\
\text { on }\end{array}$ & mömu \\
\hline \multicolumn{2}{|l|}{$\begin{array}{l}\text { pixö' } \\
\text { where }\end{array}$} & $\begin{array}{l}\text { nö'nöikda } \\
\text { ot them will se }\end{array}$ & $\begin{array}{r}\text { 'gu'rahu } \\
\text { aside }\end{array}$ \\
\hline $\begin{array}{l}\text { pixö' } \\
\text { where }\end{array}$ & & $\begin{array}{l}\text { uoídaG } \\
\text { hey belong. }\end{array}$ & $\begin{array}{r}\text { aniamh } \\
\text { I not }\end{array}$ \\
\hline
\end{tabular}

kuhapu.pwicồp ni'cam‘átud ganavarThen thus also I them cause to know that= ci'vgo'k ö'hi tötvakwö'p·ta which is seven beautiful skies beneath nampua'r'gidic kumi'mömu'rin'ka porki that they form that they hence selves will take because

niti'anatö ani'tuako'k·daD'a kuni'puI if here them see I them will sicken. Then= ma·tup ganci'u'k kui'bu.intök'da I cause to know that my Morning Star, that= hither me will extend

gano'vid para nawö 'c.o'ras.a'bthat his hand in order that he in all hours= in' $u^{\prime} k \cdot d i d a \quad k u m i a ' m$.pihö'tunko'k'datud'a me will go guarding where me will sicken

ganamarictukö'dam they which are vicious ones.

há'gicdara ganci'u'G pardon he my Morning Star ganampuanihöpukíkiö

they which hereabouts live

namarnána·skör

that they are scorpions, namarkók'o ha'ctunampu.i'ntampukikiổ that they are snakes, any that they here reside. kumi'.mömu''rna Then they hence selves will take that which is green ma''inikwö't'a kuniamho' 'hi petate beneath.

Then I not wish

nananö'nöik·da konki'hapí nicmátut that I them will see. With which thus is, I cause= to know

ganavarinci'u'k

he that is my Morning Star.

tunha.'gicid Me pardon

naparinci'u'k' naparinda.'D in. ${ }^{\cdot}{ }^{\prime} \mathrm{k}$ that thou art my Morning Star, .that thou art my= Mother, my Father.

\section{NOTE}

This prayer is recited by a man when he goes to a new locality to build his house and make his home. It has the power to drive away the scorpions, snakes, spiders, and other poisonous insects and animals.

He must first fast for five days and prepare a jicara of pinole mixed in water or of holy water. This jicara is decorated with small beads. At the end of the fast it is placed in the center of the holding and the water sprinkled to the four cardinal points while the prayer is recited. The latter is addressed to the Morning Star, the arch-enemy of the scorpions who are the cattle of the Devil. The principal scorpion is in the sky $;^{1}$ those on earth are smaller copies of it.

The prayer must be repeated every year if the scorpions are to be kept under control.

\section{TRANSLATION}

Hail! thou who art my Morning Star. Thou wilt come to watch over me that no evil may come upon me from those who dwell

${ }^{1}$ Probably borrowed from the European zodiac. 
hereabouts upon the earth, the poisonous scorpions which here wander.

Likewise do I beseech them that they take themselves hence where I may not behold them, away where they belong. I do not wish to see them hereabouts where I walk. Also do I give them to know, formed as they are beneath the seven beautiful heavens, that they must take themselves hence, for if I behold them hereabouts I will sicken them.

Also do I beseech my Morning Star that he reach unto me his hand to shield me through all hours. Then will these poisonous ones not sicken me. Therefore do I beseech him, my Morning Star, that he restrain them who live in this hill, the scorpions, the spiders, the serpents, and all those who here dwell. They must take themselves beneath the green carpet, for I do not wish to behold them.

Thus do I say unto my Morning Star. Forgive me, my Morning Star, my Lord and my Lady.

\section{TO OBTAIN A SERPENT PROTECTOR}

adiu's naparin. $Q^{\cdot} \mathrm{k}$ naparinda.'D
To God that thou art my Father, that thou=
art my Mother.

pimi'tunha'gicda kuni'da'gia hi'di ko Ye me will pardon that I will seize this snake i'ntám na'nitpuvatö ku'nibö'k'ta here that I did already find. That I will carry inki'amhá para natun'úk·turid·a my home to in order that he for me will guard. hi'di navarictödo This that is green napuoídak napuma'r'git hacnaci'dúdu that he belongs that he is formed as that hoards napu.i'ntám napumváp’án kuvin.oída that he here that he is stretched out. Then me will= accompany

pihö nanpunxöpit inki'a'm napumtötök where that I me rest, my home that it is called para natun'úkturid·a ha'ctunanpihö'dákta in order that he for me will guard anything that= I anywhere will leave

pihö'van a'npusoi"ma‘c hi'di oi'dadá·m where I sad appear this world on. kuha'pu.ö·p. ani'ctanim ha'gicdara Then thus also I am begging pardon hidi navarictödo mai'nikdám pihö this that is green petate on where nanpusoi"mac navarci'vgo'k ohi that I sad appear that is seven beautiful tö'tvakwö'pta kuhi'di ko skies beneath. Then this snake aviamipihöinö·p·kiöD’a

he not anywhere me will frighten. Then I beg

hágicdara kuvi'.möm.u'rin'ka pixö pardon that he hence self will shelve where nanda' $\mathrm{k} \cdot \mathrm{ta} \quad$ kuviamiadak ${ }^{\prime}$ taka that I will leave. Then not them will leave nampihötunha'nid'a ganha'ha'cdun that they anywhere me will meddle that my relations, kumiamha'ctupixö.inbö'böitciD·a kuvi'athat they not anything anywhere me will steal. Then= wu'pu'rda amti'pihö'hactucinvwídi·cdam he them will tie they if anywhere anything me= with wish to take.

kuvia'mi.ada'k·taka gökö ni'putá'n Then not them will leave. Therefore I beg favor kuvi'n.oída inki'amhá' favor that me will accompany my home to. kuhapu.ö'p' nicmátud gan.Q.' $\mathrm{p}^{\text {. }}$ Then thus also I cause to know that my= Father,

inda·'t nampunmákkim lisensia hi'di my Mother, that they me give permission this oi'dadám na'npugamtönöídim hidi world on that I going beholding this go*k va'ik tóno'r nanitpua"two three sun that I did already= cimácit kuhapu.ô·p· avi'pkindák.ta appear that thus also he also yet me= 
$\begin{array}{lrrr}\text { hidi } & \text { gok } & \text { vaik } & \text { tóno'r } \\ \text { this } & \text { two } & \text { three } & \text { sun }\end{array}$ nani pkicihúrun·da that I also yet will set. inka'ök dios pöcumvi'ak'a me hear. God thee will sympathize.

\section{NOTE}

Large constrictor serpents are said to live in the forests of the Sierra Madre Occidental above Azqueltán and these are claimed to make excellent pets and house guardians. ${ }^{1}$ If properly approached they will accompany the finder to his house and guard it for him. They give notice of danger by striking the ground with the tail and bind and hold any one who may come with intent to rob. If the owner is asleep they strike him in the face with the tail to awaken him. But they must be given bread to eat every Thursday if they are to remain content.

When a man wishes to secure one of them he first buys a candle and begs permission of María Santísima in the church. Then he takes a white cloth with which to bind the snake and hunts to the four cardinal points. When he has found it he recites this prayer.

\section{TRANSLATION}

Hail! my Father and my Mother. Forgive me if I carry hence this serpent which I have found here. I will carry him to my house that he may be my guard. On this your green carpet where he belongeth was formed he who lieth here. He must go with me to where I rest, my home as it is called, to keep watch for me over anything which I may leave wherever I do mournfully appear in this world.

Thus do I pray here where I do sadly appear on this green carpet beneath the seven beautiful heavens. This serpent must not frighten me. I beg that he may stay hidden wherever I may put him. He must

\footnotetext{
${ }^{1}$ Cf. Lumholtz, Unknown Mexico, II, p. I24.
}

not allow my neighbors to meddle anywhere nor to steal from me. He must wrap himself around them if they come to rob me of anything. He shall not permit them. Therefore do I ask the favor that he accompany me to my home.

Likewise do I say unto my Father and my Mother who have given me leave to go beholding in this world these few days which have dawned, that they shall still allow me yet a few days which shall yet come to a close.

Know it to be thus and hear me! May God bless thee.

\section{TO BEG RICHES OF THE TOLOACHE}
adio's na'paring.'G' na'parinda'D To God that thou art my Father, that thou art= my Mother.

pi'tunhá'gicda ku.a.'ni.a'nsapiwi'nartun'Thou me wilt pardon that I, I say, to him me= ma'kia gako't'rup ${ }^{2}$ a'nihö' will give that Toloache ${ }^{2}$ hereabouts nampudádaR ganavargö'gur that they are seated that which are great tö'hungid’ám anihö' hasnaci'dúdu rock-piles on hereabouts thus that hoards. kuni'puta'n'ia gagö'gu'cdara Then I will beg that fortune ave'r.ti'nsokore.'rota ku'intane.'tiD'a to see if me will succor. Then me will lend gagö'gucdara gö'kuni'puamtán há'gicdara that fortune. Therefore I you beg pardon napimaringö'korak that ye are my manes

vö'puhímdam before go on.

kuhapu.pïcö’p ni'cta'n gahá'gicdara Then thus also I beg that pardon gako't'rup' kupimima'kia lise'nsia anihö that Toloache. Then ye will give permission. Hereabouts

nampudáda·r ha'snaci'dúdu ci'arwöt·ahöwan that they are seated thus that hoards east beneath= there

\footnotetext{
2 Nahua toloatzin, Datura stramonium.
} 


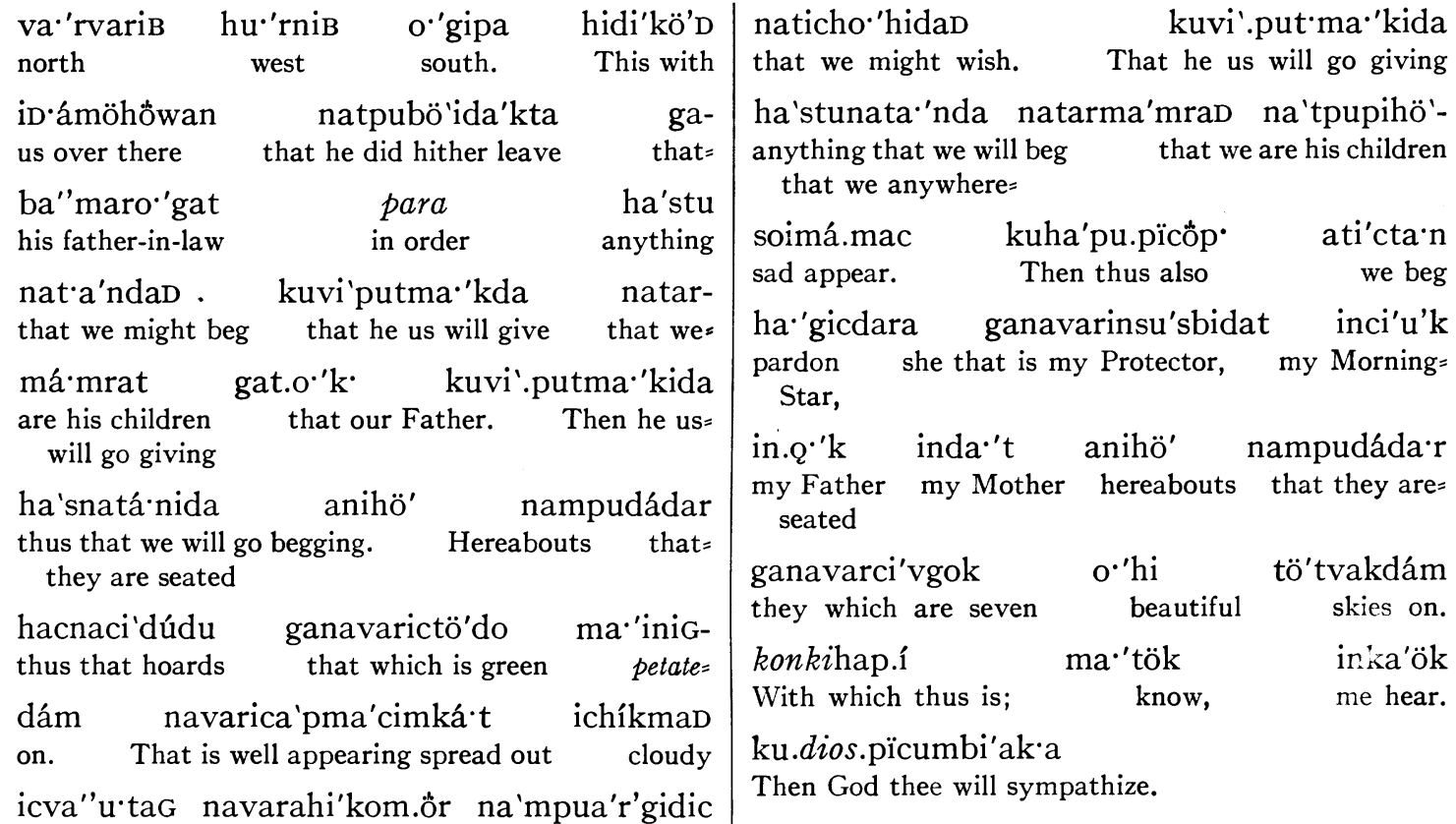
drizzly which is their cloud within that= they form

ganavargö'gur tö'hongid’ám anihö' ci'ko•r that which is great rock-piles on hereabouts vicinity

\begin{tabular}{|c|c|c|}
\hline $\begin{array}{l}\text { puha 'kagö·cim } \\
\text { returning }\end{array}$ & $\begin{array}{l}\text { ba''variB } \\
\text { north }\end{array}$ & $\begin{array}{r}\text { hu'r'niB } \\
\text { west }\end{array}$ \\
\hline $\begin{array}{l}\text { o.'gipa } \\
\text { south. }\end{array}$ & $\begin{array}{l}\text { hidi'kö't } \\
\text { This with }\end{array}$ & $\begin{array}{l}\text { navarictö'doG } \\
\text { which is green }\end{array}$ \\
\hline $\begin{array}{l}\text { tö'vagá'pa } \\
\text { sky in }\end{array}$ & $\begin{array}{l}\text { puva'kúg'atim } \\
\text { already finishing }\end{array}$ & $\begin{array}{r}\text { hi'di } \\
\text { this }\end{array}$ \\
\hline $\begin{array}{l}\text { hö'mat } \\
\text { ne }\end{array}$ & $\begin{array}{l}\text { go' } G \\
\text { two }\end{array}$ & $\begin{array}{l}\text { ní.Q } \\
\text { w }\end{array}$ \\
\hline
\end{tabular}

natpuhö'kö'tbö'i.a'r'gidic hi'di oi'dadám that he did with hither form this world on.

kuti'cpuawö't'amó'mgia gana'varci'vgok Then we them beneath will bow they which are seven $\begin{array}{lrr}\mathrm{o}^{\cdot} \text { 'hi } & \text { tö't'vakwöt·a } & \text { pihö'dör } \\ \text { beautiful } & \text { skies beneath } & \text { where from }\end{array}$ na'tpuböid·a'ktá na'varid’á·D pa'ra that she did hither us leave that she is our= Mother in order

natpután.dad gako't'r'up' ha'stuthat we should beg that Toloache anything=

\section{NOTE}

The toloache is a plant of great power, being the son-in-law of the Father Sun. He attained this by reason of his marriage to the Corn Daughter. But he mistreated her by having two mistresses, Crow and Mapuache, and was fastened head-downward in the ground, his limbs outstretched and was commanded to give mortals whatever they might beg of him. ${ }^{1}$

It is said to have a thick trunk of nine inches diameter and no roots, growing on the bare rock. Its five branches extend to the cardinal points and to heaven. It is made of money and each one has a jicara full of coin in front of it. One may borrow this money and return it in five years time. But having done so, he may not attend confession. Or he may beg fortune which will later be vouchsafed to him. Needless to say, the toloache is an extremely rare plant in the Tepecano country.

To beg fortune of the toloache one must first fast seven days for María Santísima and ${ }^{1} C f$. JAFL, xxvir, $\mathrm{I} 60$. 
go to church and recite this prayer to her to beg her permission. Then he fasts forty days for the toloache. He goes to the river and finds a black stone which has a child, a smaller black stone, beside it. These two he takes away, the smaller one for María Santísima, the larger one to pay the toloache. He also carries a bastón decorated with cotton and a jicara decorated with beads. Going to the toloache, he recites this prayer and leaves the offerings there. Soon thereafter he attains great wealth.

\section{TRANSLATION}

Hail! thou who art my Father and Mother. Thou wilt forgive me for I am about to give myself unto the Toloaches who are seated round about among the great rocks. I will beg fortune of one of them, if perchance he may succor me and lend me riches.

Therefore do I beg your forgiveness, my spirits who have gone before. And likewise do I beg forgiveness of the Toloache; ye shall give me leave to do so.

Round about are they seated in their places beneath the east, the north, the west and the south. There did their father-in-law who is above us put them that they should render unto us whatever we might crave, who are the children of the Father. They must give us whatever we ask. Round about are they seated on the verdant carpet. Within their drizzly cloud, beautifully o'ercast, were they formed, from whence they returned hither to the great rocky slopes to north, west and south.

So doth ascend unto the blue heavens these few words with which he was created in this world. So do we bow our heads beneath the seven beautiful heavens from whence our Mother sent us to beg of the Toloache whatever we might crave. $\mathrm{He}$ must grant us, the children of the Father, whatever we may wish, wherever we may appear.
Likewise do we beg forgiveness of my Lord and my Lady, my Guide and Morning Star there where they are seated in the seven beautiful heavens.

Know it to be thus and hear me! May God bless thee.

\section{TO BEG FORTUNE OF THE HILLS}

adio's naparin. $0^{\circ} \mathrm{G}^{\cdot}$ naparinda'D To God that thou art my Father, that thou= art my Mother,

anihö' napimpudáda·r ci'kor

hereabouts that ye are seated vicinity

xövwan gana'varicapma'cim am-

there that which is well appearing your=

a'tockardám navarichi'kmat.ká'D navaricseat on which is cloudy, outspread which is= va"u'tak anihö̀ na'pimpudá.da·r drizzly. Hereabouts that ye are seated hasnaci'.dúdu na'pimpubö'.it'nöídim thus that hoards that ye hither us watching gana'varumbu'p'uivashöku't. navaramthose which are thy faces with which are= ka'k'varik navarumu"umi pihö'dör your chimales. Which are thy ceremonial arrows wherefrom

napu.iwá' $\mathrm{N}$ ganavarhíko'm ganavarci'vgo'k that it rises that which is cloud that which is= seven

o`hi tötvaGwö'tadờr kuti'c.pu.amtá'n beautiful skies beneath from. Then we= you beg

há'gicdara pihơdör na'pimitbö'.inió pardon where from that ye did hither speak gaci'vgo'k amni"'o'khök'u't ha'p·u that seven your word with thus namita'pam.hơ'k ha'pu hákia that they did already also you reply thus same ni'o•khờkö't kuna'mita'pautá lise•nsia word with. Then that they did already also you begged permission

para na'mpu.itma'k·ia gaha'ctu in order that they us will give that anything 


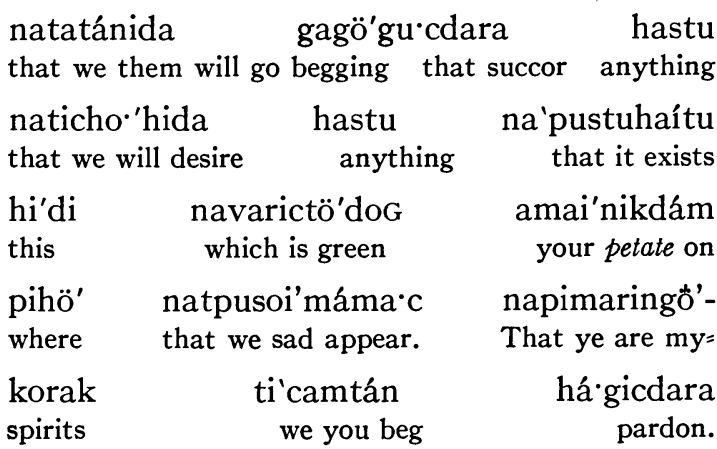

ku'pimi'tuthá'gicda ti'cputö'maiamsá'kcit Then ye us will pardon. We continually to you weep

ha' 'cnapuci'dúdu

thus that hoards

na'pimaringô.korak

that ye are my manes

napimpusoi.máma'c

that ye sad appear

na'pimpuanihö'.dádar that ye hereabouts are seated

ci"arwöt·ahö̀ east beneath there

bá'varip hu''rnip north west

o.'gipa koha'pu.pwic.öp'

south. Then thus also

ni'camtán

há·gicdara

pardon ku'pimi'nma'kia that ye me will give

nanpuavwi'tunma'kia gana'mpuanihö'tukiö. that I with them me will give they who hereabouts= reside

ganavarictutuk

that which is black

$$
\begin{aligned}
& \text { o'hi } \\
& \text { beautiful }
\end{aligned}
$$

oídak ·ába

kumia'mpihö'.cin·ờ'da

Then they not anywhere me will ignore. me will give

ha 'ctunanpihö'.atá'nida

anything that I anywhere them will beg. hereabouts

namputukík·iö that they dwell

tổvakwoỏp·ta

sky beneath us extend

gana'varumnóv that which is thy hand

natitpua'tá that we did begged

\section{ganavarci'vgo'k'} that which is seven I you beg

lise'nsia permission hill in.

\section{ha'pu.pwi'cöp}

thus also

hiditákugumökö't

this fragment with,

acumwádda

itself will make

icxö'pitkamököt

cold with

\section{gana 'varamu"umi.ökö't}

ticamtá·n

we you beg

há·gicdara

pardon

they which are your ceremonial arrows with those= which are your=

ka'k'varik ganavaramci'cvoD pihö'dör chimales with those which are your plumes where= from

napuböi.hík·mad

that it hither clouds up.

ni cpuamá't'ut

I you cause to know

napimaringökorak

that ye are my manes.

pöcamári'dak·am

you smallness.

\section{NOTE}

The surrounding hills or cerros are elements of the greatest importance in the religion of this region and the more important ones have their particular habitant spirits. These can grant wealth to mortals if properly approached. The method displays a strange mixture of Christian and pagan philosophy but the prayer is purely aboriginal.

When one has determined to sell himself ganihơ That $=$ to the hills in return for fortune he first fasts seven days for María Santísima. At midnight on the seventh day he goes to the church carrying a lighted twenty-five cent candle and says this prayer to sever his connection with the church. Then he rests several days, bathes himself and then fasts forty days. At the end of this fast he goes to one of the principal hills carrying a jicara decorated with small beads (chaquira) and many larger beads for payment. There he says the prayer again and leaves the offering. 
From a neighboring spring he takes a gourd of water and carries it to his cornfield (coámil). Here he sprinkles it to the four corners and in the middle while reciting the prayer for the third time. After he has sown and reapt his crop he becomes very wealthy. He may not go to confession thenceforth and every fifth of May he must go to the hill to repeat his vows. Every fifth year he must repeat the fast and the visit to church.

\section{TRANSLATION}

Hail! my Father and my Mother, seated somewhere on your pleasant throne, o'erspread with drizzly clouds. From there where ye are seated do ye gaze upon us with your countenances, which are your chimales. From your arrows ariseth the cloud from beneath the seven beautiful heavens. We beg your forgiveness. From there did ye speak your seven words and they replied unto you with the same words. They besought you that they might grant us anything which we might crave of them, that they might succor us with anything we might wish upon this your green carpet where mournfully we appear.

We also beg your forgiveness, my spirits. And ye will forgive us. Continually do we cry unto you, my spirits, seated there beneath the east, the north, the west and the south, where ye do sadly appear.

Likewise do I beseech you that ye grant me leave to give myself unto them who live hereabouts in the beautiful dark hill. They must not refuse me; they must give me whatever I may ask of them. Hereabouts do they dwell beneath the seven beautiful heavens whence ye did reach unto us your hand into which we were gathered when we begged succor.

So with this fragment do we beseech you that no evil may come upon us and that we may not be sickened. With all the cold will ye cleanse us; with your arrows, your chimales and your plumes whence spring the clouds.

Thus do I give ye to know. Hear me, O my spirits! So be it. May God bless you.

\section{TO GAIN A SWEETHEART}

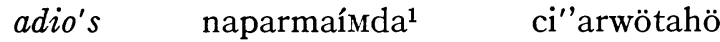

To God that thou art the intoxicated ${ }^{1}$ one east= beneath there

napu.a'rgidic napucmai'm ati'cumta'n that thou art formed that thou art intoxicated. We= thee beg

ha'gicdara navaric'i'vgo'k ${ }^{\cdot}$ óhi pardon which are seven beautiful töwakwö'ta napu.oi'dök kupi'pu.sky beneath that thou belongest. That thou=

ci'korhi'mia hö'ga na'varica'pmámcim about wilt go that which is well appearing um.a"raghök•ö't napua'r'gidic kuni'.thy form with that thou art formed. Then I= pucho'hi kupi'mai'muD'a höga desire that thou wilt cause to be intoxicated that uv nanica'pnöid ica'pmámcim xio'cig woman whom I well see well appearing flower nanpuhö'köta'rgidic that I with am formed.

kuha'pi.pwicö·p Then thus also

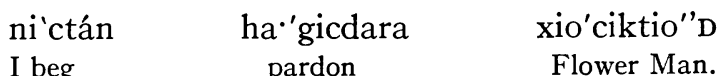
ku'nihö'kö.pua''r'gidic navaricap.mámcim Then I with am formed which is well appearing $\mathrm{u}^{\cdot}$ par $^{2} \quad$ xio'cgi nanpuhö'kökötuí guisache ${ }^{2}$ flower that I with am decorated. kuvi'naptötu'gia höga uv Then with me shall behold that woman nanica'pnöíd kuni'pucho'hi na.ina'pwhom I good see. Then I desire that she with me= tötu'gia kuvia'maass hömai shall behold. Then not more other xio'ci'k ica'pma.'cka mas flower well shall appear more

1 Intoxicated with peyote.

2 Nahua huisatzin, probably Pithecolobium albicans. 
At midnight, when the girl is asleep, a candle is lighted and the two figures placed in a jicara or bowl of water where they float. The prayer is then recited and a ceremonial song sung five times to the accompaniment of the musical bow. Five ceremonial circuits of the bowl are then made and the charm is complete. If the figures have floated together, the prayer will be answered; if they have parted, the case is hopeless.

The prayer is replete with allegory and ceremonial allusions.

\section{TRANSLATION}

Hail! thou who art called the Intoxicated Woman who wast created beneath the east, intoxicated. We beg thy forgiveness, thou that belongest beneath the seven beautiful heavens. Thou shalt return, formed as thou art with thy beauteous figure. I ask that thou wilt intoxicate the woman whom I crave, who am arrayed with pretty flowers.

Likewise do I beseech the Flower Man. For I am arrayed with the pretty flower of guizache. She must look upon me, this woman whom I covet; I ask that she look upon me, that no other flower shall please her but the one with which I am arrayed, sadly appearing here. She must not crave another flower but that with which I am arrayed, the flower of palo mulato. This only shall she like. And likewise the flowers of rosa maría and garambullo of which I am made. I wish that she shall want me, this woman whom I crave, who was created beneath the seven beautiful heavens. Beneath the east did she appear, arrayed with pretty flowers. Thence did her father and her mother send her, arrayed with her beauteous form.

Likewise do I beseech her father and her mother that they forgive me. She must give herself unto me, this woman whom I covet. For I am arrayed with the flower of toloache. Therefore do I ask that this woman shall want me, and also she who is called the
Intoxicated Woman who belongeth beneath the seven beautiful heavens.

Thus do I beseech the Flower Man who dwelleth on the great rocky slopes.

So be it. May God bless you.

\section{TO SECURE A BRIDE}

a'nicbö'him a'piam.ha'pum.a.'gat i'nimồ I hither come; thou not thus shouldst think here

konticanböidu'viag to"nimör.va.umni'ok·iD that I did here hither have arrived unbidden= already to thee speak.

\begin{tabular}{|c|c|c|}
\hline $\begin{array}{l}\text { pero } \\
\text { But }\end{array}$ & $\begin{array}{l}\text { höga'k-ö't } \\
\text { that-with }\end{array}$ & $\begin{array}{l}\text { api'ctunha'gicda } \\
\text { thou me wilt pardon }\end{array}$ \\
\hline $\begin{array}{l}\text { porke } \\
\text { because }\end{array}$ & $\begin{array}{l}\text { na' 'numnöit } \\
\text { that I thee behold }\end{array}$ & $\begin{array}{l}\text { na'psc } \\
\text { that th }\end{array}$ \\
\hline
\end{tabular}

ku'höga'köt anicto"nimör.ba"umnio'k $k$ it Then that-with I unbidden already thee speak.

ku'animök.mödör namaivanioki dios

Then afar-from that he hence already speaks God na'pua'ptuí' ci'vgo'k: o॰'hi tö'tvakthat he is seven beautiful skies= dam abimö' natpuvahö'madi ${ }^{1}$ on. There that he ${ }^{1}$ did already= create

nava'rdö'öt. $\quad$ o'gat $\quad$ hŏgga who is her mother her father that ci'vgo $k^{\cdot}$ hi'komöra höga seven cloud within. That navaric.tö'dok $\quad \mathrm{o}{ }^{\prime}$ hi ha'vu.öra which is green beautiful jicara within natpuhö'mad·idak natpuhivisaptúk dồu't that he did form that he did hide carry her= mother

$o \cdot$ 'gat natpuanihö'vam'a'ci'r ta'tpan her father. Then she did hereabouts appear in= the legs

natpuvaso's’oigim natsa'sa kuamihö'dör that she did already sorrowing that she did= weep. Then there-from

${ }^{1}$ The parents seem to be generally spoken of in the singular number, inclusively. 
na'tpuai'vavom ${ }^{1}$

that she ${ }^{1}$ did already arise

navarictödö

which is green

o.'hi

beautiful

natpuva't•ököhi

that she did already tread

amihö'van natpuva.a.'rgi ha'cmacimö'köt'

There that she did already form any appearance with

na'p'ua."rak'

höga

that she form

that

dö"u•t•

o'gat ku.a'midör natpu.aivawo'mik

her father. Then therefrom that she did already= arise

napuvatönö'id·im höga navarictuma'M that she already beholding that which is five

hi'kom.ör napubava.a.'rgidim navaric.tö'do cloud within that she hither already forming which= is green

o'hi hi'komagidö'k'öt' natpugamivavomit beautiful his cloud with. That she did already= raise

natpuvanö'id·im hởga

that she already beholding that

ma'mcim

hi'k'om

appearances

cloud

hö"kia so many örhö'van within

abihö'van na'pubava'sa'kim sa'kumgidthere that she hither already sorrowing her tears= ö'köt' na'puida'giunim napugamamö'ringia with that she goes cleansing. That she will run hikom.örhu'van napubavama''rgidida cloud within

forming

hö'gactumám ci'c.wordadö'köt'

navar.that five his plumes with who is her

o'gat' ha'ban'dö̀r nabai'vaha'duG father which-from that hither already........ nabai'vavi' $\eta$ i nabai'vahi'koma that hither already.... that hither already clouds up. $\begin{aligned} & \text { kua'bimöhödör } \\ & \text { Then there-from }\end{aligned}$
that

${ }^{1}$ From here on, the reference of the third person singular is very equivocal. It seems to refer to the peregrinations of the girl before birth but may refer to the journey of the Word as, apparently, is the case in the very similar prayer, No. 2. ö·rhö'dör napubaiva'niok·im hög·a within-from that hither already goes speaking that

navaric.da'dikam

which is health

hi'kom.örhö'van cloud within

na'pubavamhö'git·

ku.a'mimö'dur.that hither already replies. Then there-from in two= go'kpan.tötu'gia napubavatunö'idim aric.places will see that hither already beholding. Is=

tö'd`o o॰'hi ba'hakörhö'dör green beautiful broom within-from

amihö napubavamö'ringim napubavam.there that hither already comes running, that= hither already self=

a.'rgidim aric.tö'do hi'komhö'kö't is forming is green cloud with.

na·pubava'nöidim

That hither already watching

navaruma.'ingiat which is his petate

avarica 'pma.'cimnaka.'t'

it is well appearing outspread

ari $\cdot$ cha''duk'am

is..............

aricvi' $\eta$ gikam aricva"utaG'at aric-

........... is drizzly is

tö'tgitna'ka't höga na'varuma'ing'at his green, outspread that which is his petate.

ku.amihö'dör napuivo'pmid'a navaric.Then there-from that will raise which iss

da'dik·am navarva"u'tagit napu.hö'kö'thealth which is his drizzle that he with=

baivada'giuna na'varumarat a'midör hither already will cleanse who is his child. Therefrom

avimivo'mikda

napuhö'kö't.uma''rgida she hence will arise that she with self will form

gög•ör o'hi va'hak'hökö't great beautiful broom with.

napuvatötö'gia arictö'do va'mör.ö'r amihö'

That she already will behold is green lake= within there

napuvatönö'idida amihö' napuvama•'rgid·a that she already will go watching. There that= she already self will form

tö'do o.'hi hi'komö'k•ö't green beautiful cloud with. 


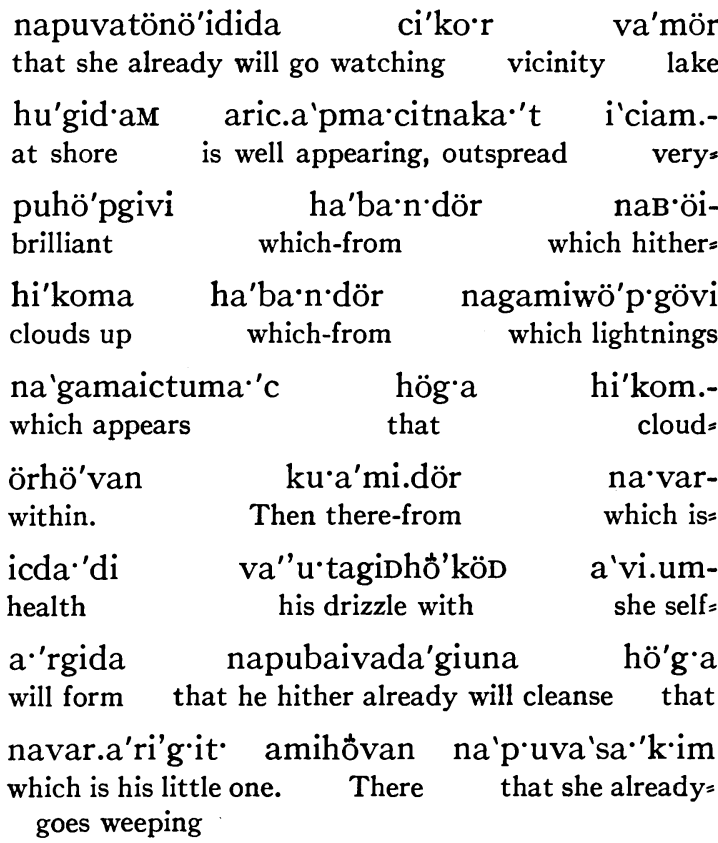

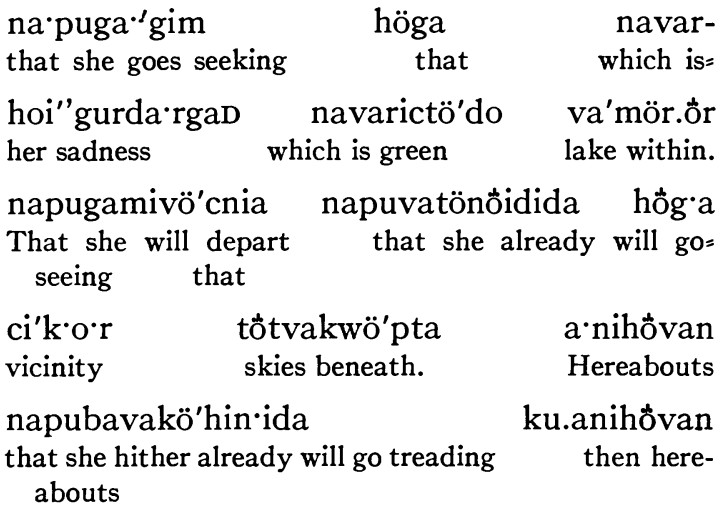

ha'cnatpu.o'imör navardö'u't o.'gat' as that she did walk which is her mother her father.

$\mathrm{ku}$ 'hacmacimhö'köt' natpuma.'rgida ${ }^{1} \mathrm{ku}-$ That what appearance with that she did self will= form, ${ }^{1}$ then=

ha'pu.ma•'cim.hơ'köD natpubia.'rgi navthus appearance with that she did hither form that= a·rmá'raD a'ric.tumso'soi'gim sa'sa`Gsa'gi·D is her child is sad weeping between. amihö' napuvakö' 'hinim napuvaThere that she already treading that she already=

${ }^{1}$ Probably incorrectly given; future suffix probably superfluous. ma'mciria

will appear

aric.tồd $\cdot 0$

o'hi

is green

beautiful

hi'komörhö'van napuva.uma.'rgida aric.cloud within that she already will be formed is= tö'do o.'hi so'so'p navartöid green beautiful bead which is his garment hö'ganavar.o'gad he that is her father.

ku.a'mi.dör Then there=from napuvatönöidida navar.va'viar o.'hi that she already will go seeing which is gray beautiful tö'vakwöt'a na'varic.a.'m va'viar $\quad o^{\circ}$ 'hi sky beneath that is yellow gray beautiful mai'ngiD·am kuanihönapuvadu'via his petate on. Then hereabouts that she already= arrives

navaruma'rgida

vaviar

ohi that she self will form gray beautiful

navarci'cwo'd·adök•öt'

which are her plumes with.

ku.a'mihö Then there

napuatonö'idida va'paviar o.'hi that already will go seeing gray beautiful vahak.ör na·puvahö'ködambö'himöt' broom within that she with hither having come va'paviar o*'hi navarci'cwodat gray beautiful which are her plumes nahök·ödamda'giuna ku.a'mihơvan that she with self will cleanse. Then there-from natpuvawu'p'au navardô'u·D o'gaD that she did them equall who is her mother, her= father.

ha'c.macimhö'köt na'tpuvam.a.'rgi What appearance with that she did already self form, kupuma'cimhö'k·öD avi'c.upa"rak. then appearance with he also forms nava'rma'rad kuamihö'dör who is his child.

Then there-from natpugamatönö'idida ${ }^{2}$ aric.tumám o॰'hi that she did will go seeing ${ }^{2}$ is five beautiful hi'kom.öra ku.a'mi'dör natpuvam.a''rgi cloud within. Then there-from that she did= already self form

${ }^{2}$ Probably incorrectly given; future suffix probably superfluous. 


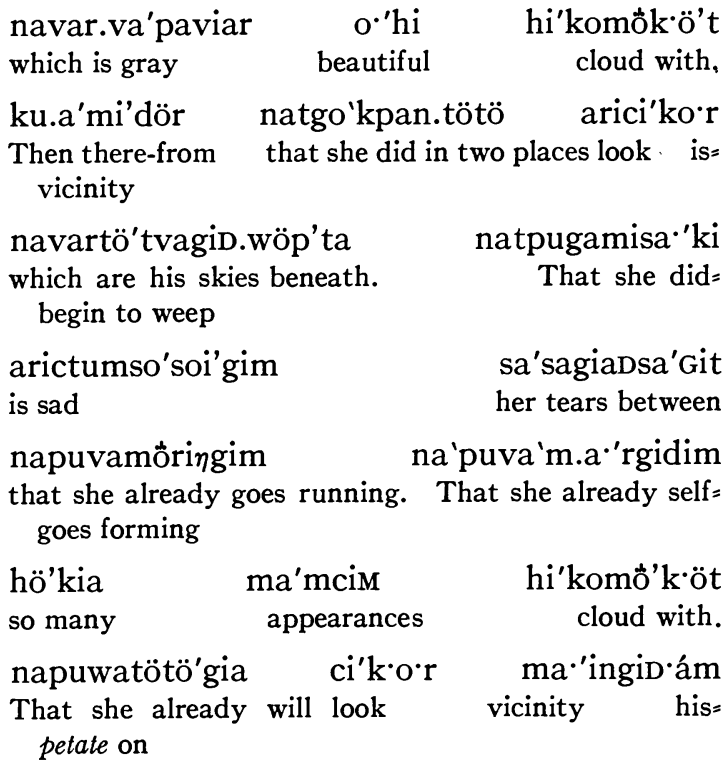

napuvatönö'idida hu'r'nip' aricthat she already will go seeing west is=

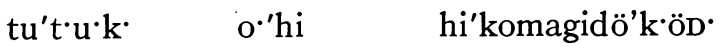
black beautiful his cloud with na'puvama'rgida kua'mi ha'cnatuma•'rgi that she already will be formed. Then there as that= she was formed

\begin{tabular}{|c|c|}
\hline $\begin{array}{l}\text { dö'u't. } \\
\text { her mother, }\end{array}$ & $\begin{array}{l}\text { kupuma'cimhö'k·öt' } \\
\text { that appearance with }\end{array}$ \\
\hline $\begin{array}{l}\text { avi'c.up'a.'r'ak } \\
\text { she also form. }\end{array}$ & $\begin{array}{l}\text { k kua'mi.dör } \\
\text { Then there-from }\end{array}$ \\
\hline $\begin{array}{l}\text { vo'pmig } \\
\text { raise }\end{array}$ & $\begin{array}{l}\text { aric.a'pma'mcim } \\
\text { is well appearing }\end{array}$ \\
\hline $\begin{array}{l}\text { hi'komó'köt' } \\
\text { cloud with } \\
\text { cleanse }\end{array}$ & $\begin{array}{l}\text { natöpkibaivada'giu } \\
\text { that he did also now hither already= }\end{array}$ \\
\hline $\begin{array}{l}\text { navaruma''r'aG } \\
\text { which is thy form. }\end{array}$ & $\begin{array}{l}\text { natpuida'gid gö'gucdara } \\
\text { That he did send succor }\end{array}$ \\
\hline $\begin{array}{l}\text { da'dik } \\
\text { health }\end{array}$ & $\begin{array}{l}\text { nathö'ködgami- } \\
\text { that he did with= }\end{array}$ \\
\hline $\begin{array}{l}\text { tö'vu'rtör } \mathrm{n} \\
\text { increase which }\end{array}$ & $\begin{array}{l}\text { navar.ör } \cdot d \cdot a k \cdot a m \text { kuvi'pu'p'- } \\
h \text { is inwardness. Then he thus also= }\end{array}$ \\
\hline $\begin{array}{l}\text { kima' kim } \\
\text { now giving }\end{array}$ & $\begin{array}{l}\text { gö'gucdara na'gamaipupkitö- } \\
\text { succor which he thus also now= }\end{array}$ \\
\hline
\end{tabular}

kö'hina hi'di a'tvaGsa.'giD ku'.will tread this altar between. Then= amihö'van napuvatötu'g·ia na`varictúk· there that she already will see which is black o'hi va'mör.ör amihơ na'p•uda beautiful lake within there that is seated navardö'u't' o'gat ' napuvamaida'who is her mother her father. That he already= giunim navaricda'dik'aM u'u'migidö'köD hence cleansing which is health his ceremonial= arrows with

nagamiwi'cturda icko'kdakam i·ctónkam that he will repel sickness heat.

ku.inimö napuvamörin'ogim na'puvása·'kim Then here that she already goes running that she already goes weeping

naga'gimöt ' hö̀'a navarhoi'gurdargat that she went seeking that which is her sadness. ku.a'mi.dör nagamivo'mgia i'ctumá'M Then there-from that she will arise five hi'komagidö'köt na'pugama.iwö•'cnia his cloud with that she will depart.

na'tpuvapnö'idida ${ }^{2} \quad$ ci'ko'r va'mör.öra That she did already also will go beholding ${ }^{2}$ vicinity lake within
aric.a'pma'c.itka'D

is well appearing outspread

aricvi'nigat a'midör

is......... There-from

navarhi'k•om

which is cloud

wö'p'gövi

lightens

ha'ba·ndör which-from na'gamaictuma.'c

aricha'dugat is.......... naivo'pmik that it arises that it appears. Then there-from that she already= tö'gia höga navarvo'p'oigiD.a'ba will see that which are his paths in na'pubavakö'hinim hö"ga navaricthat she hither already goes treading. That which iss da·'dik'am hi'komagidö'k'ö't hö'kö'dumhealth his cloud with with self was=

2 Probably incorrectly given; past prefix probably superfluous. 


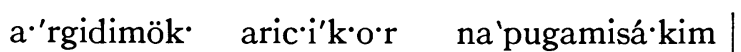
forming. Is vicinity that she weeping ci'ko'ri'pas na·gamikö•hinim a'ri.ci'ko'r vicinity that she goes treading. Is vicinity na'pubaivaha'dug na'gamivi'ngi ari.that hither already..... that....... is all= ci'ko'ri'pas ha"dör nabihi'komaG hi'komaround to-from that hither clouds up cloud= sá'git na·'gamiwöpgöv vo'p·oigiDa'p·dö·r between that lightnings his paths in-from nabaivá'u'ta abimödö·r nabaivatö'tvak ${ }^{1}$ that hither already drizzles. There-from that= hither already skies ${ }^{1}$

nabaiva.va"u'tak aric.tö'do ma'indam that hither already drizzles is green petate on aric.a'pma'c arictö'tgid aricva"u'tag $i$ is well appearing is his green is drizzly aric.hádu'Gat' ada'maN ati'am.tö'ka'k is.......... Above she did self place na'tpubaivad'a'gim that he did hither already sending nava'rma'rat' who is his child. natpugamaivavom hu'kia ma.'mcim That she did hence already arise so many appearances hi'komö'rhờvan nap'uvat'önöidim aricta' cloud within that she already beholding is white o'hi tốvakwö'ta aricta' o'hi beautiful sky beneath. Is white beautiful mai'ngid‘ám a'mihờ na'puvadúvia his petate on there that she already arrives na'tpuvam.a.'rgi aricta.'ta o.'hi that she did already self form is white beautiful hi'komagidö'köt' natpugamai.vatötö his cloud with. That she did hither already see a'ric.tuma'M hơ'kia ma'mcim is five so many appearances hi'kom.örr kua'mi.dör na'tpuva'tönö'idim cloud within. Then there-from that she did= already beholding

navaricta'ta that is white

$$
\text { o'hi }
$$$$
\text { beautiful }
$$

va'ha'k.öra broom within amihö' napuamö'ringim there that she already running. aric.ta'ta Is white

${ }^{1}$ Possibly incorrect, verbal form with nominal stem. o'hi u'umigidö'köt' na'puhö'köt.beautiful his ceremonial arrows with that she= bama·'rgidim ku.ámi.dör natwith hither self forming. Then there-from that= go'k'pan.tötö na'puvatötu'gia aric.ta' she did in two places look that she already will= see is white

o'hi va'mör.ör amihö beautiful lake within there napuvadu'via va'pamör.örhödör that she already arrives. Lakes within-from na'puvam•ö'rin`ogim navarvámör hu'that she already goes running that is lake on= gid·aN napugamasa'kim arictumsosoi'gim shore that she weeping is pitiful sa'sa'gid sa.'gid napugama'niok'im her tears within that she speaking napuga'gim that she seeking

navar.ho'i'gur.dargat which is her sadness navar.dú'ut' o.'gat' ku.a'mi.hödör who is her mother her father. Then there-from na'tpuva'm.a.'rgi that she did already self form navaric.da.'diG which is health sa'kumgidơ'köt na'tpuivo'pmid navar.her weeping with. That did raise which are= ci'cvordat' na'tpugamaivakugat aric·ikor his plumes that did already finish is vicinity $\begin{array}{llr}\begin{array}{l}\text { tŏttvakwöpta } \\ \text { skies beneath }\end{array} & \text { ci"a·rwöta } & \text { ba'barip } \\ \text { east beneath } & \text { north }\end{array}$ hur’nip o'gipas ku.amihödör west south. Then there-from pu'iwómik' na.'varmárat ' ida'giuna raise who is his child will cleanse navarichöpitkam da'dikam napubövatöwhich is cold health that he hither already= tö'gid`a navaric.tö'do o॰'hi so'so'p. to see that is green beautiful bead= will cause a'tockarad’ám napubava.u'rna his seat on that he hither already will raise.

THE REPLY OF THE FATHER OF THE GIRL

ha'pu.pi'cam.a.'gat hapu.tu.óip'u hö'g·a Thus also ye were thinking thus walk. That 
inmár ave'ma`'t ha'ctuna'c.du'nia my child she not know anything that she will do. ave'ma.'t töt'ut'u'a' avicicto'o'hot' She not know to grind. She lazy. pero apimtic.a.'pnö-it kuha'pu.pimi'soi'da But ye if well see then thus ye will suffer. kuaviam.hactu.dám Then not anything over. napimitaivagö'gu that ye did already halt i.'bwimda yourselves tire ku.i'nimö̀ That here napimit'atumko'k·dat napimitci' 'wa.umtá·t.that ye did already= napimita 'cihu't'ua that ye did already yourselves sicken.

hö'.gamihöwan a 'piambi'ak' $a^{1}$ thou not wilt need ${ }^{1}$ napimha'cum.a.'ka that ye any will think.

hactuda'köt

anything with

navar.ö'ra·dakam which is inwardness

That there hactu.da'köD anything with api'miam.bi'ak'a Ye not will need napimsa'sa'kida that ye will weep namaritgö"korak that they are our manes. ku'amihövan ha'pu.ni'cup.tá'n ha•'gicdara Then there thus I also beg pardon wö'puhímdam namaritgö'korak ago'kipbefore go on that they are our manes two parts= dör na’pima'rma'mrat ' navarito 'G. from. That ye are his children who is our Father, iD·a't itci'u'k ha'pu.pwi'c our Mother, our Morning Star. Thus a'mi.dör amiböiamda'giuna navaric.there-from they hither you will cleanse which is= da'dik'am navarumxi'komak'hö'köt ${ }^{2}$ health which is thy cloud with ${ }^{2}$

namgamaitumtö'gicda that they thee will cause to see.

namivo'pmigda That they will raise nvaricda.'dikam navarumu"umi which is health which are thy ceremonial arrows line.

${ }^{1}$ Possibly error for apimiam-, YE NOT, as in next

2 The use of the second person singular in these lines is quite puzzling.

nam.hö'köD.gamaiumwö'ctu•rda

navaricthat they with from thee will repulse which is= ko'k'dakam aric·i'ko'r nava·rtö'tvakwö'pta sickness is vicinity which is skies beneath. kuha'ban'dör namivo'p·migda hö'kia Then which-from that they will raise so many ma'mcim ahi'komak na'mgamai.amappearances their cloud that they selves will= a.'rgida ku.a'mimödö·r go'kpan.putö'gia form. Then there-from two places will see navar.hö'kia ma'Mcim hi'kom.ör which are so many appearances cloud within. ku.a'mi.dör nam.hö'kköD.puvatuda'giuna Then there-from that they with already will cleanse navaraxi'komak navarada $\cdot$ 'diG which is their cloud which is their health navarava"utak. kugaku a'bi.mödör which is their drizzle. Then therefore there-from apimictunha''gicd·a porke i'nimot ye me will pardon because here nanitaivamnö̀ip uctur navargo $\mathrm{k}^{\cdot} \quad$ va'ik that I did already to you relate , that is two three ni'.o'k porke hactöi.dök ${ }^{\cdot}$ a'viam.word because anything it nots acic.bai'gid nanaha'kiacturda na·varanyhow is able that $\mathrm{I}$ for them will recount which= ama"rak ${ }^{3} \quad$ namaritgö"korag hög·a are your forms ${ }^{3}$ that they are our manes that ha'puvi'cima.'c avi'ricda"rakam thus appears it is dear avaric·idukam inwi'dúr porke anicaricit is treasure me with-from because I am= i'krakam tö'vur.da'm.kam ${ }^{4}$ kugökö vile wind overness. ${ }^{4}$ Then therefore

a'ban·dör

which-from

nanavö'p·auvturda that I them will equal

hactu'i'duk' anything aviam.ha'cic.bai'gid it not anyhow is able

navara.a'rak porke which is their form because ku'amöhövan.pubö'.then there hither=

${ }^{3}$ Probably should be -a.a" $r a k$, THEIR FORMS.

${ }^{4}$ The accuracy of this phrase is very questionable. 
ima $c$

appears.

nanamka'icturdaD

that I for you should hear

a'ricap'ma•'cim

is well appearing.

inmár dios

my child God

intindimiento

willing

a'pimpimicho'hidat

Ye, ye were desiring

hŏ̉ga

that

$\mathrm{ni}^{\prime} \mathrm{o} \cdot \mathrm{k} \cdot$

word

höga.ti'am.she if=

nanö'ködama"turda ${ }^{1}$

pero

that I with to you will teach. ${ }^{1} \quad$ But might be

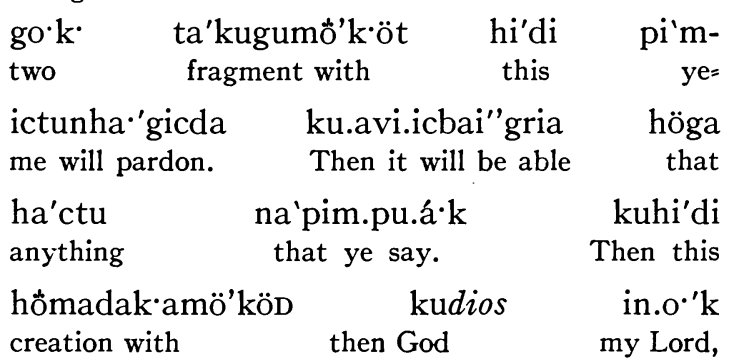

inda.'t inci'u'k ku.höga'köt.gamtu.my Lady, my Morning Star. Then with that= amtögicda api'migamai.pwöptököhina you will cause to see ye begin thus also will tread

navarmai'ngiD`am aric.a'pma'citnaka't which is his petate on is well appearing, outspread.

avarichi'komagat da'man'dör nagamiIt is his cloud above from

that $=$

ha'dug nagamivi'ngi' ha'ban'dör na.it..... that it.... which-from that ivo'p'migit navarci'cwo'rdaD aric· $i^{\prime} \mathrm{k} \cdot \mathrm{o} \cdot \mathrm{r}$ he raises which are his plumes

napubima'ma.c

that hither appears

xur'nip o'gipas

west south.

tö'tvakdam

ci"a·rwöt·a

east beneath

is vicinity

va'varip

north

arici'vgo $\mathrm{k}^{\cdot} \quad \mathrm{o}^{\prime}$ 'hi Is seven

beautiful

navaric.da'dikam tö'do

that it is health green

navarda'kam that she is sitter

navariD·a·'D nabai.it'ö'kiD

u'vikam womankind who is our Mother extends which is her hand

navarno'vid

1 The exact meaning here is dubious. natha'bantudá kuhi'di hö'madakamököt that she did in it seize. Then this creation with pictunha'gicda dios pi'amhacum·a'k·a thou me wilt pardon God thou not anything wilt= think.

\section{NOTE}

This long and involved prayer is spoken to the father of a girl desired in marriage. ${ }^{2}$ Marriage generally takes place at about the age of eighteen. The details having been arranged informally, the husband-to-be and his father appear at the house of the girl on a Wednesday night. It happens that at present only two Tepecanos know this long prayer and one of them must be engaged at a fee of a peso per night to accompany the supplicants and recite the prayer. It must be recited five times on successive evenings, Wednesday, Saturday, Wednesday, Saturday and Wednesday. On the final night the father makes his reply. Since the affair is always prearranged, the reply is never negative.

Then a white cloth is spread out and the clothes and other property of the girl and the wedding gifts placed upon it. The bride and groom and their fathers each seize a corner and raise the cloth and the ceremony is complete.

After this they are married. The boy gives a present to his parents-in-law and goes to live with them for a short period, six months or a year before setting up a separate home. Two wedding feasts and dances are held, one in the house of each parent.

The prayer is extremely long and involved and so full of ceremonial and esoteric allusions as to be very difficult of proper translation. In many cases the exact meaning is very doubtful and obscure.

\section{TRANSLATION}

Hither have I come. Do not wonder that I have come here to speak unto thee unbidden. Thou wilt forgive me, for I behold that thou

\footnotetext{
${ }^{2}$ Cf. Lumholtz, Unknown Mexico, II, p. 93.
} 
art sad. Therefore do I thus unbidden speak unto thee.

From afar God speaketh from his seven beautiful heavens. There did her father and her mother create her within the seven clouds; within the beautiful green jicara where she was formed did she carry her hidden, until at last she appeared between the limbs, sorrowfully weeping.

Then she arose and trod on the beautiful green carpet where she was formed in the image of her father and her mother. From there she arose and went observing within the five clouds, where she was formed of his beautiful green cloud. Then she arose, gazing within the many-colored cloud and wept, cleansing it with her tears. Within the cloud will she run about, being formed of the five plumes of her Father from which spring the clouds and the rain. From within that cloud he speaketh and within the healthful cloud is answered. From there will she look in two directions, observing. From within the beautiful green broom-grass she cometh running, being formed of the green cloud. She looketh down upon his green carpet, beautifully outspread with fog and drizzly rains. His carpet is verdantly spread out. From there he will draw his welcome drizzle with which he will purify his child. Thence will she arise and be formed of the great beautiful broom-grass. Within the green lake which she watcheth will she gaze. There will she be formed of the beautiful green cloud. She will gaze all around on the shores of the sparkling lake, beautifully outspread, whence rise the clouds. From within these clouds flash the lightnings. There will she be formed of the healthful drizzle with which he will purify his little one. There she goeth about weeping, seeking her sorrow within the green lake. She will depart and will gaze about beneath the heavens. Here will she come to tread just as have her father and her mother walked. In the same likeness as were her parents created, so did they form their child, with sad tears. There will she appear, walking within the beautiful green cloud where will be formed the beautiful green bead which is the garment of the Father.

From there will she go beholding on his beautiful golden gray carpet beneath the beautiful gray heaven. There she arriveth where she will be formed with her beautiful gray plumes. Within the beautiful gray broom-grass will she gaze, purifying herself with her beautiful gray plumes, with which she came. Thus did she resemble her father and her mother. In the same likeness as were they formed, so also did they form their child. Then did she go beholding within the five beautiful clouds; there was she formed of the beautiful gray cloud.

Thence did she look to both sides round about beneath his heavens. She began to weep, running about amidst sad tears. With many forms of cloud is she created. Round about doth she gaze upon his carpet, looking to the west where she will be formed of his beautiful black cloud. As were formed her father and her mother, so with the same likeness do they create her. Thence did he lift his graceful cloud with which he did purify her form. He sent succor and health in his cloud, thereby augmenting his spirit. So also doth he now send succor to him who will tread between this his altar. There will she gaze into the beautiful black lake where are seated her father and her mother. With his health will he purify and with his arrows will he cast out sickness and heat. Here, running sadly about, did she seek her sorrow. Thence will she arise with his five clouds and depart. She will gaze within the lake, beautifully spread out with rain and fog. From there ariseth the cloud within which flash the lightnings. Thence will she look upon his paths where she treadeth. With his health-giving cloud is she formed. All around doth she go wandering and weeping. Round about it raineth and showereth and cloudeth up and within the cloud flash the lightnings. 
From his paths cometh the drizzle. From afar cometh the drizzle on his pleasant green carpet. From there above where she was placed did he send hither his child.

Then did she arise within the many-colored cloud, gazing beneath the beautiful white heaven. On his beautiful white carpet did she arrive and was formed of his beautiful white cloud. She gazed within the five many-colored clouds. Thence did she go gazing within the beautiful white broom-grass where she was running. With his beautiful white arrows is she formed. Thence did she glance to both sides, gazing into the beautiful white lake where she now arriveth. From within the lakes she goeth running along the shore, pitifully weeping and speaking through her tears, seeking her father and her mother in her sadness. There was she formed with her health-giving tears.

Thus did he raise his plumes unto the end round about beneath the heavens to east, north, west and south. Lifting from there his child he will purify her with the cold, the health. He will give her sight and raise her unto the beautiful green bead which is on his throne.

\section{THE REPLY OF THE FATHER OF THE GIRL}

With this thought have ye come. But my child knoweth nothing. She cannot grind corn; she is lazy. But if ye so desire, so must ye endure. May no ill ensue. Here have ye stopped; ye have tired yourselves, ye have stumbled and hurt yourselves. But do not think of that. Neither weep; it is the will of our spirits.

I also beseech our spirits who have gone before from both sides. Ye are the children of our Lord, our Lady, our Morning Star. From afar will they come to purify you with their healthful cloud, and will give you sight. They will bring health and with their arrows will they repel the pestilence round about beneath the heavens. From them will they draw their cloud of many colors with which they will be formed. Thence will they look to both sides within the many-colored cloud. Thence will they cleanse with their cloud and their health-giving drizzle.

Ye will forgive me because I have recited unto you only a few words. For I cannot repeat to you the formulas of our spirits as they appear. For they are rare and are cherished; they depart from me to the winds, for I am vile. Therefore I cannot imitate their formula, for it appeareth afar. You desired that I should hear your word clearly. But if my child so wishes, God willing, I will teach you. But nevertheless ye must forgive me these few fragments. Then will ye be enabled to say anything.

With this formula, God, my Lord, my Lady, my Morning Star. With this he will give you sight, ye who will tread thus his carpet, pleasantly outspread. From his cloud above come the rains and fogs from which he raiseth his plumes which appear all about beneath the east, the north, the west and the south.

There in the seven beautiful heavens sitteth the healthful Green Woman who is our Lady who reacheth unto us her hand that we may be gathered into it.

So with this formula forgive me God, thou who holdest no malice.

\section{TO BEG PARDON WHEN ANGRY WITH ANOTHER}

adiosum anicbö'himdat to"nimör.To God. I hither was coming unbidden already= vaciumnio'k·idim piambi'ak'a pihönapsoi'thee speaking. Thou not wilt need anywhere= mörid·a anicumta'nim ha'gicdara that thou sad wilt feel. I thee am begging pardon. pero höga'köt• piambi'ak'a napaBut that with thou not wilt need that thou in= go'kip.tönö'nikda two places wilt look. seize 
höganamaritgö'korak

they that are our spirits

kuha'pu.pwö'cö·p·

Then thus also

höga navarito''k napuböit॰ö'kdim höga

that who is our Father who hither us is extending that

$\begin{array}{ll}\text { navarno'vit' } & \text { para } \\ \text { which is his hand } & \text { in order } \\ \text { tönö'idim } & \text { wöc } \\ \text { beholding } & \text { all }\end{array}$

natpuga'm'that we going= before go on. pimica·ptumda'gia namputso.'sbit'urdim gacto'nkam höga That they for us protecting that heat that navara.u"umihököt. navaraka'k'varak which are their ceremonial arrows with which are= their chimales

navarawu'p'uivas höga'k•öt' mi'pugama'.which are their faces this with they= itwï'ct'urdim gacko'k·dakam höga for us repelling that sickness. That navariD·a·'D navaritna'na wadalupi who is our Mother who is our mama Guadalupe awi'putnöidim para nata'niD'a she us watching in order that we shall go begging ha.'gicdara pardon. havaganavarit.o.' $\mathrm{k} \cdot$ santontie."ru San Anton Tierra they hither us will go guarding And he who is our Father amipuböit.nu'kdida wöc orasa'ba kuaviamha'ctud·am.all hours in that not anything over us= $\mathrm{a} \cdot{ }^{\prime}$ cumdu'nia $\quad k o^{\prime} n k i ́ h a p \cdot \mathrm{i} \quad$ hö'gia itself will make. With which thus only ni'cpum·a'tup kupiambi'a'ka nap·iI thee cause to know. Then thou not wilt need that= hö'wan.soi'mö'rida i'n'vwi' kupi'thou anywhere sad wilt feel me with. Then thou= captumda'gia navarinsu'spidat . inci'u'k. in him thyself wilt seize who is my Protector, my= Morning Star,

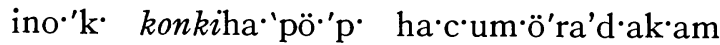
my Father. With which thus also any thy= withinness.

NOTE

When one person is angry with another or on bad terms with him and wishes to resume amicable relations, he goes to the other's house and recites to him the following prayer.

The influence of Christian theology is unusually evident.

\section{TRANSLATION}

Greetings! Unbidden have I come hither to speak unto thee. Thou must not feel angry; I come to beg forgiveness. Neither look askance. Thou must be possessed of the spirits of those who have gone before. Thou must be possessed likewise of our Father who reacheth unto us his hand that we may go beholding throughout all hours. With their arrows do they protect us from the heat and with their chimales, which are their faces, they cast from us the plague. She who is our Lady, our Mother of Guadalupe, is watching us that we beg forgiveness. And $\mathrm{He}$ who is our Father, San Anton Tierra, will guard us throughout all hours that no evil may befall us.

This only do I say unto thee. Thou needst not feel angry at me. Thou must be possessed of my Lord, my Guide and Morning Star. Thus be thy thought. 